\title{
Synthesis of Diaminopimelic Acid Containing Peptidoglycan Fragments and Tracheal Cytotoxin (TCT) and Investigation of Their Biological Functions
}

\author{
Akiko Kawasaki, ${ }^{[a]}$ Yukie Karasudani, ${ }^{\left[{ }^{[a]}\right.}$ Yuji Otsuka, ${ }^{[a]}$ Mizuho Hasegawa, ${ }^{[b]}$ \\ Naohiro Inohara, ${ }^{[b, c]}$ Yukari Fujimoto, ${ }^{*[a]}$ and Koichi Fukase ${ }^{*[a]}$
}

\begin{abstract}
Bacterial cell wall peptidoglycan (PGN) is a potent immunostimulator and immune adjuvant. The PGN of Gram-negative bacteria and some Gram-positive bacteria contain meso-diaminopimelic acid (mesoDAP), and we have recently shown that the intracellular protein Nod1 is a PGN receptor and recognizes DAPcontaining peptides. In this study, we achieved the synthesis of DAP-containing PGN fragments, including the first chemical synthesis of tracheal cytotoxin (TCT), GlcNAc-( $\beta 1-4)$-(anhydro)Mur-
\end{abstract}

NAc-L-Ala- $\gamma$-D-Glu-meso-DAP-D-Ala, and a repeating-unit of DAP-type PGN, GlcNAc-( $\beta 1-4)$-MurNAc-L-Ala$\gamma$-D-Glu-meso-DAP-D-Ala. For the synthesis of PGN fragments, we first established a new synthetic method for an orthogonally protected meso-DAP derivative, and then we constructed the glycopeptide structures. The ability of

Keywords: carbohydrates
immunochemistry $\cdot$ peptides
tracheal cytotoxin

these fragments to stimulate human Nod1, as well as differences in Nod1 recognition of the variety of synthesized ligand structures were examined. The results showed that the substitution of the $\mathrm{N}$ terminus of $\mathrm{iE}-\mathrm{DAP}$ is necessary for stronger Nod1 recognition, but the structure of the substituent seems not to be strictly recognized. The importance of the carboxyl group at the 2-position of DAP for human Nod1 stimulation was also shown.

\section{Introduction}

Innate immunity is the first line of defense against microorganisms, and is activated when pathogen-recognizing receptors (PRRs) recognize particular molecules that are commonly found in microbes. ${ }^{[1]}$ PPRs include membrane-bound Toll-like receptors (TLRs), cytosolic Nod-like receptors

[a] Dr. A. Kawasaki, Y. Karasudani, Y. Otsuka, Dr. Y. Fujimoto, Prof. K. Fukase

Department of Chemistry, Graduate School of Science

Osaka University, Toyonaka

Osaka 560-0043 (Japan)

Fax: (+81)6-6850-5419

E-mail: yukarif@chem.sci.osaka-u.ac.jp

[b] Dr. M. Hasegawa, Prof. N. Inohara

Department of Pathology

The University of Michigan Medical School

Ann Arbor, MI 48109 (USA)

[c] Prof. N. Inohara

Department of Biochemistry 2nd

Interdisciplinary Graduate School of Medicine and Engineering University of Yamanashi

Yamanashi, 409-3898 (Japan)
(NLRs), and RIG-I family proteins. Common microbial components recognized by PRRs include bacterial peptidoglycan (PGN), lipopolysaccharide (LPS), lipoproteins, flagellin, DNA, RNA, and also viral RNA. PGN is a component of the bacterial cell wall, and consists of polysaccharide chains linked to peptides. The polysaccharide is a $\beta(1-4)$ glycan composed of alternating $N$-acetylglucosamine (GlcNAc) and $N$-acetylmuramic acid (MurNAc); the carboxyl group of MurNAc is the point of linkage to the peptide. At the branched position of the peptide, there is usually a diaminocarboxylic acid, such as L-Lys (in Gram-positive bacteria) or meso-diaminopimelic acid (meso-DAP, in Gram-negative bacteria and some Gram-positive bacteria). PGN has been known as a potent immunostimulator and an immune adjuvant. Recently, Inohara et al. and Philpott et al independently showed that the intracellular protein Nod1, which is the founding member of the NLR protein family, is a receptor against PGN fragments (muropeptides). ${ }^{[2,3]}$ Philpott et al. reported that Nod1 senses DAP-containing muropeptides, such as GlcNAc-MurNAc-L-Ala- $\gamma$-D-Glu-meso$\mathrm{DAP},{ }^{[2]}$ whereas we showed a DAP-containing smaller peptide, iE-DAP ( $\gamma$-D-glutamyl diaminopimelic acid), activates Nod1 by using PGN synthetic peptide fragments. ${ }^{[3]}$ It was also shown that meso-DAP itself activates Nod1 of human 
epithelial cells from various tissues. ${ }^{[4]}$ Another intracellular protein, Nod2, recognizes PGN with a muramyl dipeptide (MDP) structure. ${ }^{[5,6]}$

Our recent findings showed that Gram-negative bacteria and certain Gram-positive bacteria that have DAP-type PGN secrete Nod1 ligands to the environment, ${ }^{[7]}$ and the immune system seems to be regulated by the level of these ligands. Genetic studies have linked polymorphisms in the human Nod1 gene with susceptibility to several diseases, including allergic diseases, such as asthma, ${ }^{[8-10]}$ Crohn's disease ${ }^{[11]}$ and sarcoidosis. ${ }^{[12]}$ However, the function and immunostimulatory mechanism of Nod1 are not yet well understood. Although we found potent synthetic Nod1 ligands including $N$-myristoyl-iE-DAP (KF-1B) for in vivo analysis, which enabled the investigation of the Nod1 function, ${ }^{[13,14]}$ it is also essential to understand the natural Nod1 ligands considered to be released into the environment.

It is often difficult to purify bacterial glycoconjugates, such as PGN fragments, from natural sources, because they are usually heterogeneous. In addition, the possibility of contamination of other immunostimulatory compounds cannot be eliminated even after extensive purification. We have thus synthesized a series of the PGN fragments, including Lys-type fragments found normally in Gram-positive bacteria, to study the key molecules in immune-system activation, and to determine the functions of ligands and receptors. ${ }^{[15,16]}$ The repeating unit of DAP-type PGN, GlcNAc( $\beta 1-4)$-MurNAc-L-Ala- $\gamma$-D-Glu-meso-DAP-D-Ala 1, how-
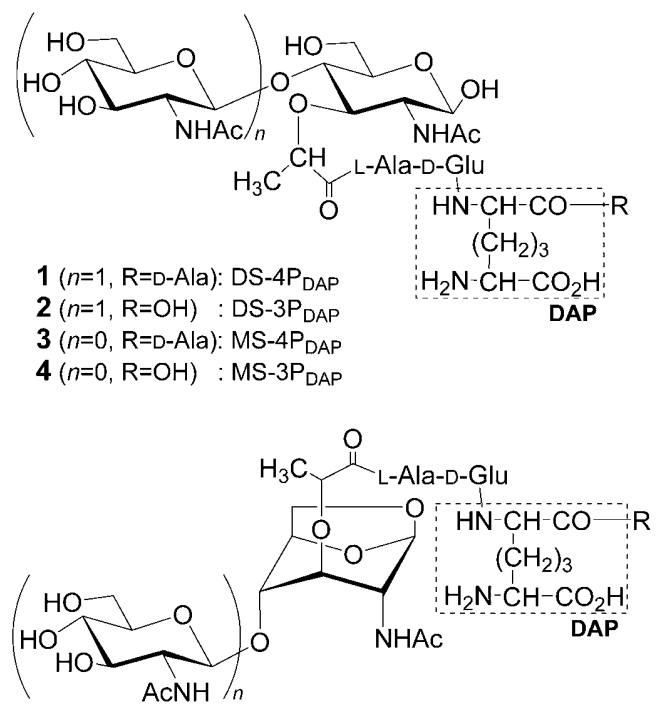

$$
\begin{aligned}
& 5(n=1, \mathrm{R}=\mathrm{D}-\mathrm{Ala}): \text { tracheal cytotoxin }(\mathrm{TCT}) \\
& \mathbf{6}(n=1, \mathrm{R}=\mathrm{OH}): \mathrm{DS}(\mathrm{anh})-3 \mathrm{P}_{\mathrm{DAP}} \\
& \mathbf{7}(n=0, \mathrm{R}=\mathrm{D}-\mathrm{Ala}): \mathrm{MS}(\mathrm{anh})-4 \mathrm{P}_{\mathrm{DAP}} \\
& \mathbf{8}(n=0, \mathrm{R}=\mathrm{OH}): \mathrm{MS}(\mathrm{anh})-3 \mathrm{P}_{\mathrm{DAP}}
\end{aligned}
$$

ever, has not been chemically synthesized, although the synthesis of monosaccharide DAP-type fragments has been performed. ${ }^{[17,18]}$
Tracheal cytotoxin (TCT) 5 was originally found as a secretion of Bordetella pertussis, the causative agent of pertussis (whooping cough). ${ }^{[19]}$ The structure of TCT was then determined as identical with GlcNAc-(anhydro)MurNAc-LAla- $\gamma$-D-Glu-meso-DAP-D-Ala. ${ }^{[20]}$ It is a naturally occurring DAP-containing fragment of Gram-negative peptidoglycan, and considered as a potent stimulator of the innate immune response. TCT shows a variety of immunological activities, including immune stimulation in hamster tracheal epithelial cells, ${ }^{[21]}$ activation of peptidoglycan recognition protein LC (PGRP-LC) in Drosophila to trigger an innate immune response, ${ }^{[22,23]}$ and stimulation of the murine (but scarcely in human) immune system by Nod1. ${ }^{[2]}$ TCT used in biological studies has been derived only from natural sources, and it has not been chemically synthesized.

In this study, we synthesized DAP-type PGN repeating unit $\mathbf{1}$, its fragments $\mathbf{2}, \mathbf{3}$, and $\mathbf{4}$, and tracheal cytotoxin (TCT) 5 and its fragments $\mathbf{6}, \mathbf{7}$, and $\mathbf{8}$ to investigate their biological functions, including stimulation of NLR. To achieve the synthesis of these DAP-containing PGN fragments, a differently protected meso-DAP is necessary. The syntheses of some alternatively protected meso-DAPs have been reported by several groups, ${ }^{[18,25-37]}$ as reviewed by Dzierzbicka. ${ }^{[38]}$ In this study, two chiral fragments were coupled to prepare the DAP backbone. We have previously studied the biological activities of DAP isomers, which include the three DAP isomers: meso-, $(2 S, 6 S)-$, and $(2 R, 6 R)-\mathrm{DAP}^{[4]}$ as well as four iE-DAP isomers: $(2 R, 6 R)-,(2 R, 6 S)-,(2 S, 6 R)-$, and $(2 S, 6 S)$-DAP. ${ }^{[13]}$ The peptide, which containes the natural $(2 S, 6 R)$-meso-DAP structure, showed the most potent Nod1 stimulatory activity. Establishing the efficient synthesis methods for these PGN fragments would lead to the new analogues with potent agonistic or antagonistic activities, and new molecular probes for the elucidation of biological function.

\section{Results and Discussion}

We synthesized meso-DAP-containing PGN fragments, including the repeating-unit of DAP-type PGN 1 and tracheal cytotoxin (TCT) $\mathbf{5}$. We have previously synthesized Lys-type PGN fragments containing muramyl dipeptide (MDP; MurNAc-L-Ala-D-isoGln), which is recognized by intracellular receptor Nod2. In this study, we focused on DAP-containing PGN fragments and their Nod1 stimulatory activities. The difference between saccharide moieties MurNAc and (anhydro)MurNAc is also of interest due to their effect on the receptor recognition. For the synthesis of these fragments, we first established a synthetic method for the orthogonally protected meso-DAP.

To prepare the meso-DAP backbone, we coupled two $\alpha$ amino acid derivatives, maintaining both chiral centers. We first attempted to use the Wittig reaction with several combinations of the intermediates (eg. Garner's aldehyde ${ }^{[39]}$ and the corresponding bromide), but most of these reactions yielded an epimeric mixture of the compounds. We then 
used Kocienski-modified Julia olefination (Scheme 1) ${ }^{[40]}$ utilizing an aldehyde $\mathbf{9}^{[41]}$ and a sulfone $\mathbf{1 0},{ }^{[42]}$ both of which were derived from $\mathrm{D}$-serine. The reaction proceeded without

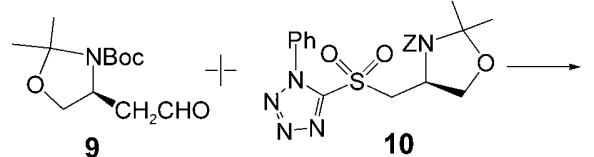

9

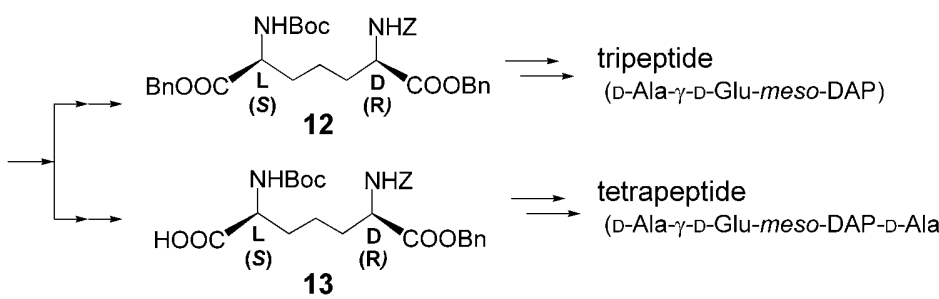

Scheme 1. Synthesis of orthogonally protected meso-DAP

epimerization to give the key intermediate 11, which was converted to the protected meso-DAP 12 and 13. Compound 12 was then used for the preparation of the tripeptide (LAla- $\gamma$-D-Glu-meso-DAP), and $\mathbf{1 3}$ was used for the tetrapeptide (L-Ala- $\gamma$-D-Glu-meso-DAP-D-Ala).

The synthesis of the protected meso-DAP 17 for the preparation of the tripeptide is shown in Scheme 2. The JuliaKocienski reaction of sulfone $\mathbf{1 0}$ with aldehyde $\mathbf{9}$, carried out with sodium hexamethyldisilazide (NaHMDS) in THF at $-70^{\circ} \mathrm{C}$, gave the key intermediate $\mathbf{1 1}$ in $71 \%$ yield. Once compound $\mathbf{1 7}$ had been formed, we used chiral HPLC analysis (CHIRALPAK AD-H, Daicel Chemical) to confirm that no epimerization had occurred in comparison with other epimers. ${ }^{[4]}$ For the synthesis of the meso-DAP derivative for tripeptide preparation, two carboxylic acids can be protected with the same benzyl esters as in compound 17. Hence, after cleavage of two isopropylidene aminals of $\mathbf{1 1}$ with $p$ toluenesulfonic acid $(p \mathrm{TsOH})$, reprotection of the cleaved

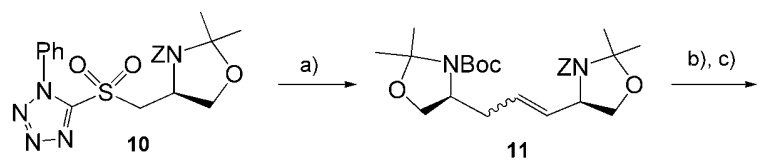

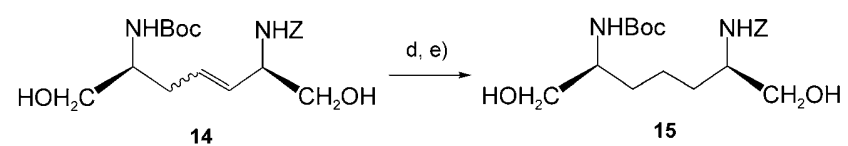

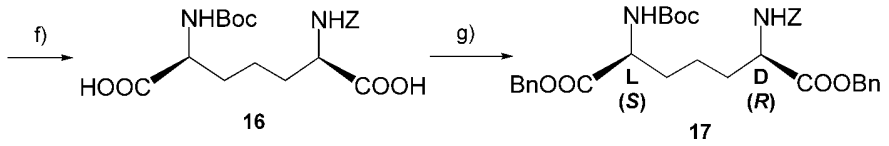

Scheme 2. Synthesis of meso-DAP derivative 17: a) NaHMDS, 9, THF, $-70{ }^{\circ} \mathrm{C}, 71 \%$; b) $p$ TsOH $\cdot \mathrm{H}_{2} \mathrm{O}$; c) $\mathrm{Boc}_{2} \mathrm{O}$, sat. $\mathrm{NaHCO}_{3}$ aq., $\mathrm{MeOH}, 92 \%$; d) $\mathrm{Pd} / \mathrm{C}, \mathrm{H}_{2}$, THF; e) $\mathrm{ZCl}, \mathrm{Et}_{3} \mathrm{~N}, 58 \%$ (for two steps); f) PDC, DMF; g) $\mathrm{BnBr}, \mathrm{Cs}_{2} \mathrm{CO}_{3}$, DMF, $61 \%$ (for two steps). amino group with a tert-butoxycarbonyl (Boc) group, and reduction of the double bond with $\mathrm{H}_{2}$ under $\mathrm{Pd} / \mathrm{C}$, both hydroxy groups of $\mathbf{1 5}$ were oxidized with pyridinium dichromate (PDC) to carboxyl groups to give 16. Selective reduction of the double bond in the presence of the benzyloxycarbonyl (Z) group in $\mathbf{1 4}$ was attempted with $\mathrm{Pd} / \mathrm{Fib},{ }^{[43]}$ but the result was not satisfactory. Thus, the deprotected amino group was reprotected with benzyl chloroformate $(\mathrm{ZCl})$. Esterification of $\mathbf{1 6}$ with benzyl bromide $(\mathrm{BnBr})$ and $\mathrm{Cs}_{2} \mathrm{CO}_{3}$ in DMF gave fully protected meso-DAP 17.

The synthesis of the protected meso-DAP $\mathbf{2 5}$ for the preparation of the tetrapeptide is shown in Scheme 3. The iso-
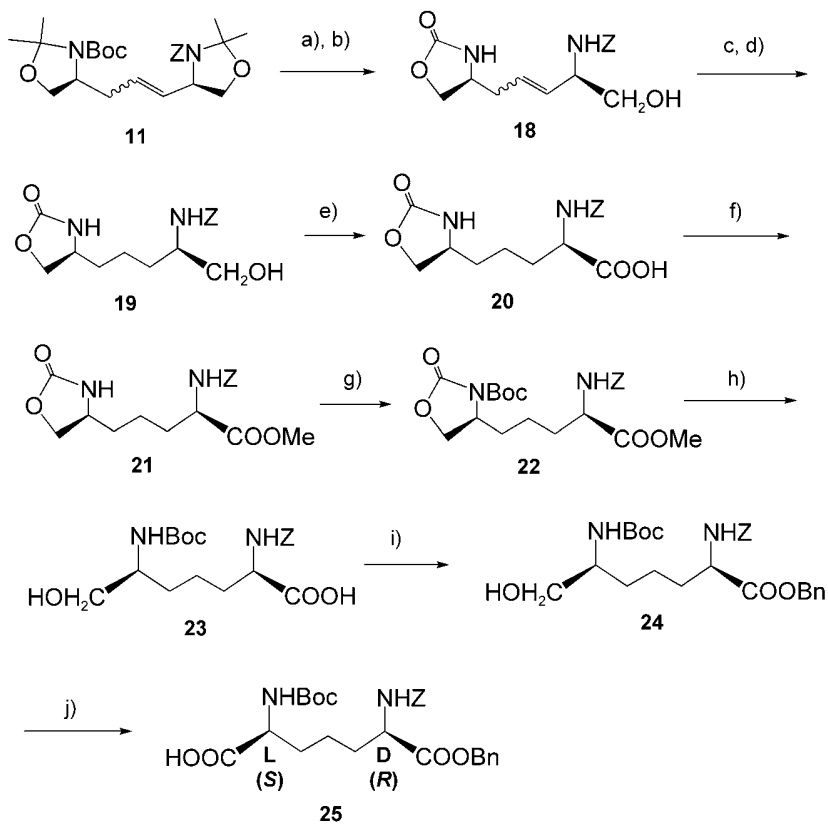

Scheme 3. Synthesis of meso-DAP derivative 25: a) $1 \mathrm{~N} \mathrm{HCl}$ in $\mathrm{MeOH}$; b) triphosgene, $\mathrm{Et}_{3} \mathrm{~N}, \mathrm{CH}_{2} \mathrm{Cl}_{2}, 22 \%$ (for two steps); c) $\mathrm{Pd} / \mathrm{C}, \mathrm{H}_{2}, \mathrm{MeOH}$; d) $\mathrm{ZCl}, \quad \mathrm{NaHCO}, \quad 1,4$-dioxane $/ \mathrm{H}_{2} \mathrm{O} \quad 1: 1, \quad 82 \%$ (for two steps); e) $\mathrm{RuCl}_{3} \cdot n \mathrm{H}_{2} \mathrm{O}, \mathrm{NaIO}_{4}$, acetone $/ \mathrm{H}_{2} \mathrm{O} 1: 1,66 \%$; f) $\mathrm{AcCl}, \mathrm{MeOH}, 89 \%$; g) $\mathrm{Boc}_{2} \mathrm{O}, \quad$ DMAP, $\quad \mathrm{Et}_{3} \mathrm{~N}, \quad \mathrm{THF}, \quad 86 \% ;$ h) $\mathrm{LiOH}, \quad \mathrm{THF} / \mathrm{H}_{2} \mathrm{O} \quad 3: 1 ;$ i) 1) $\mathrm{Cs}_{2} \mathrm{CO}_{3}, \mathrm{MeOH}$; 2) $\mathrm{BnBr}, \mathrm{DMF}, 83 \%$ from 22 ; j) PDC, DMF, $86 \%$

propylidene groups and the Boc group of $\mathbf{1 1}$ were cleaved with $1 \mathrm{M} \mathrm{HCl}$ in $\mathrm{MeOH}$, and monocarbamate formation at the liberated amino group with triphosgene and triethylamine $\left(\mathrm{Et}_{3} \mathrm{~N}\right)$ in $\mathrm{CH}_{2} \mathrm{Cl}_{2}$ gave 18. Subsequent reduction and reprotection of the amino group with the $\mathrm{Z}$ group yielded compound 19. The hydroxy group of $\mathbf{1 9}$ was oxidized to carboxylic acid 20 with $\mathrm{RuCl}_{3} \cdot n \mathrm{H}_{2} \mathrm{O}$ and $\mathrm{NaIO}_{4}$ in acetone/ $\mathrm{H}_{2} \mathrm{O} 1: 1$, and esterification by using acetyl chloride $(\mathrm{AcCl})$ in methanol under acidic conditions gave compound 21. The Boc group was introduced to the $\mathrm{NH}$ group of the carbamate by using di-tert-butyl dicarbonate $\left(\mathrm{Boc}_{2} \mathrm{O}\right), N, N$-dimethylaminopyridine (DMAP), and $\mathrm{Et}_{3} \mathrm{~N}$, and the carbamate and ester were cleaved with $\mathrm{LiOH}$ to give 23. For parts of the molecule in which the carbamate was protected with a $\mathrm{Z}$ group or there was no protecting group at the carbamate 

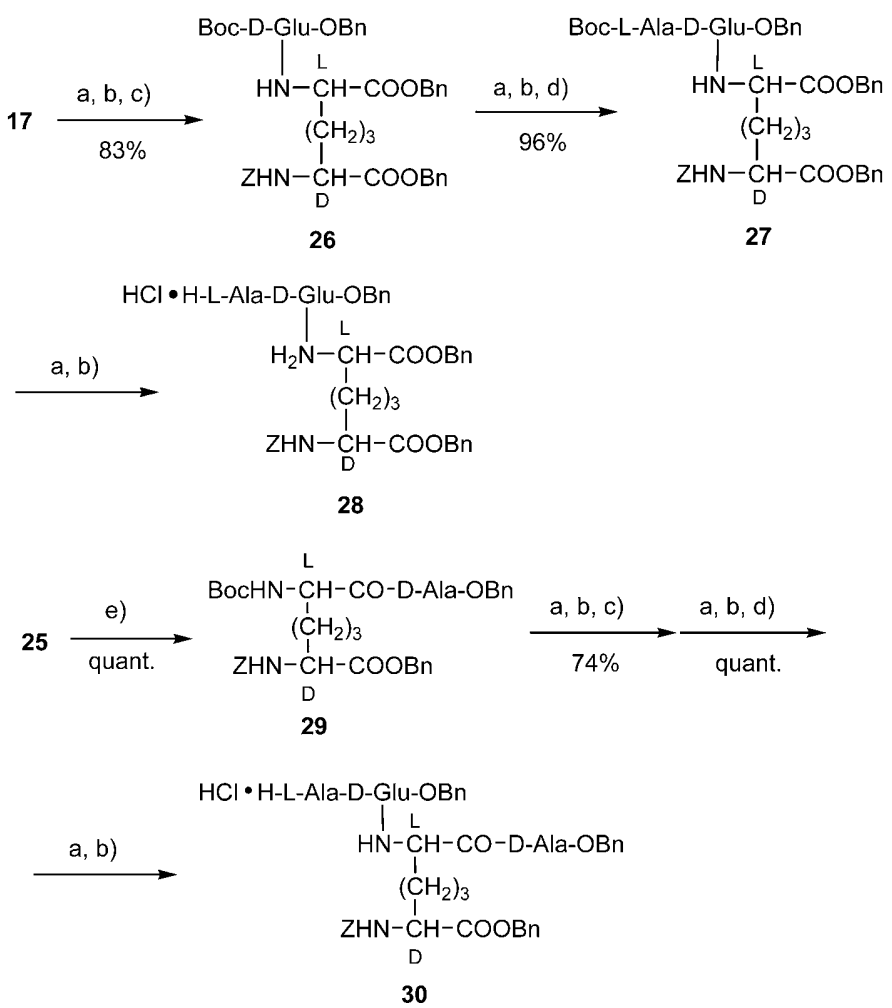

Scheme 4. Synthesis of the tripeptide $\mathbf{2 8}$ and tetrapeptide $\mathbf{3 0}$ : a) TFA; b) $\mathrm{HCl}$ in $\mathrm{Et}_{2} \mathrm{O}$; c) Boc-D-Glu-OBn, WSCD. $\mathrm{HCl}, \mathrm{HOBt}, \mathrm{Et}_{3} \mathrm{~N}$, THF; d) Boc-L-Ala-OH, WSCD-HCl, HOBt, $\mathrm{Et}_{3} \mathrm{~N}, \mathrm{THF}$; e) $\mathrm{HCl} \cdot \mathrm{H}-\mathrm{D}-\mathrm{Ala}-$ $\mathrm{OBn}, \mathrm{WSCD} \cdot \mathrm{HCl}, \mathrm{HOBt}, \mathrm{Et}_{3} \mathrm{~N}, \mathrm{THF}$.

ring, the ring-opening reaction under basic conditions did not proceed, and cleavage of the $\mathrm{Z}$ group occurred. The liberated carboxyl group of $\mathbf{2 3}$ was derivatized to a benzyl ester to give $\mathbf{2 4}$, and oxidation of the hydroxy group of $\mathbf{2 4}$ afforded the alternatively protected meso-DAP 25.

The peptide moieties, tripeptide $\mathbf{2 8}$ and tetrapeptide $\mathbf{3 0}$, were synthesized as shown in Scheme 4. For the preparation of tripeptide 28, the Boc group of protected meso-DAP 17 was cleaved with trifluoroacetic acid (TFA), and the deprotected peptide was coupled to the side-chain carboxyl group of Boc-D-Glu-OBn by using 1-ethyl-3-(3-dimethylaminopropyl) carbodiimide hydrochloride (WSCI·HCl), 1-hydroxybenzotriazole ( $\mathrm{HOBt}$ ), and triethylamine in THF to give 26. L-Alanine was introduced in a similar manner, and deprotection of the $N$-terminal Boc group gave tripeptide 28. Tetrapeptide 30 was synthesized in a similar manner by starting from 25. With these DAP-containing peptides in hand, we proceeded to the synthesis of the glycan (Scheme 5) and assembly of the peptidoglycan fragments (Scheme 6).

The anhydro-saccharides $\mathbf{3 4}$ and $\mathbf{4 0}$ were synthesized as shown in Scheme 5. Treatment of 1,6-anhydro sugar $\mathbf{3 1}^{[44,45]}$ with $\mathrm{NaH}$ followed by addition of trifluoromethanesulfonyl$(S)$-2-propionic acid ethyl ester afforded Mur(anh) derivative 32. The azide group of $\mathbf{3 2}$ was reduced with $\mathrm{Zn}$ in THF/ $\mathrm{AcOH}$, and subsequent acetylation gave compound $\mathbf{3 3}$. Cleavage of the ethyl ester gave 1,6-anhydro-muramic acid derivative 34. For disaccharide 40, the benzyl and azide groups of 32 were reduced by hydrogenation under $\mathrm{H}_{2}$ $\left(15 \mathrm{~kg} \mathrm{~cm}^{-2}\right)$ with $\mathrm{Pd}(\mathrm{OH})_{2}$ in THF to give 35 . The liberated amino group was then protected with a 2,2,2-trichloroethoxycarbonyl (Troc) group. The resulting compound $\mathbf{3 6}$ was utilized for the glycosylation with imidate $\mathbf{3 7}$ by using trimethylsilyl trifluoromethanesulfonate (TMSOTf) and molecular sieves (MS, $4 \AA$ ) in $\mathrm{CH}_{2} \mathrm{Cl}_{2}$, at $-15^{\circ} \mathrm{C}$, and gave the disaccharide 38. When the $\mathrm{N}$-acetylted acceptor was used for the glycosylation in place of $\mathbf{3 6}$, the yield of glycosylation
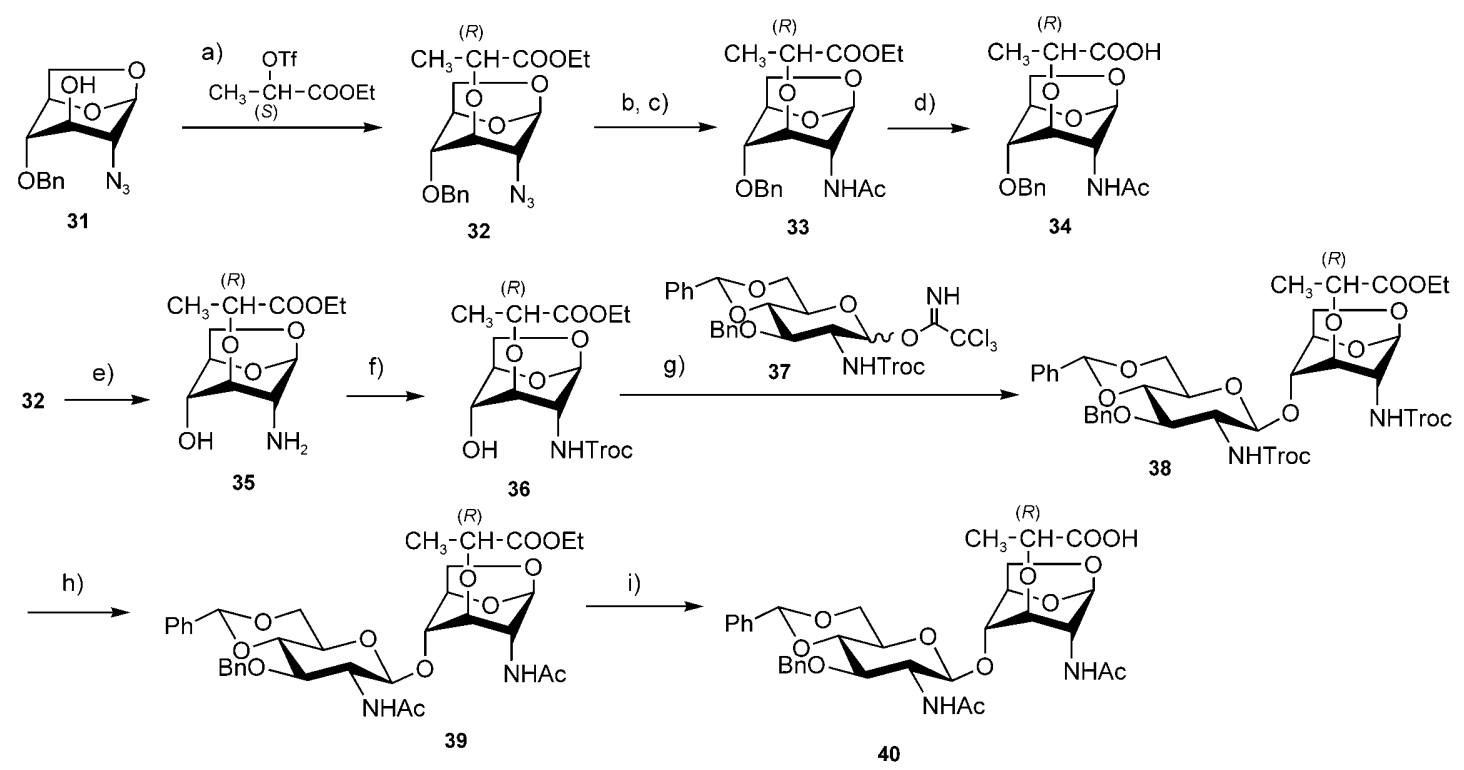

Scheme 5. Synthesis of anhydro-saccharides 34 and 40: a) $\mathrm{NaH}, \mathrm{CH}_{2} \mathrm{Cl}_{2}, 78 \%$; b) $\mathrm{Zn}$, THF/AcOH 1:1; c) Ac $\mathrm{O} / \mathrm{pyridine} 1: 1$, 79\% for two steps; d) $\mathrm{LiOH}, \mathrm{THF} / 1,4$-dioxane $/ \mathrm{H}_{2} \mathrm{O} 4: 2: 1,44 \%$; e) $\mathrm{H}_{2}\left(15 \mathrm{~kg} \mathrm{~cm}^{-2}\right), \mathrm{Pd}(\mathrm{OH})_{2}, \mathrm{THF}$; f) TrocCl, $\mathrm{Et}_{3} \mathrm{~N}, \mathrm{CH}_{2} \mathrm{Cl}_{2}, 77 \%$ for two steps; g) TMSOTf, MS (4 $\left.\mathrm{A}\right)$, $\mathrm{CH}_{2} \mathrm{Cl}_{2},-15^{\circ} \mathrm{C}, 30 \mathrm{~min}, 65 \%$; h) $\mathrm{Zn} / \mathrm{Cu}, \mathrm{AcOH} / \mathrm{THF} / \mathrm{Ac}_{2} \mathrm{O} 1: 1: 1,81 \%$; i) LiOH, THF/1,4-dioxane/ $\mathrm{H}_{2} \mathrm{O} 4: 2: 1$, quant. 


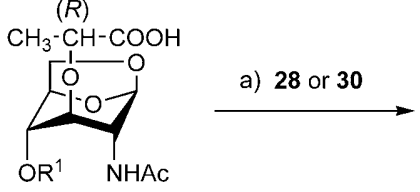

$\left.\mathrm{CH}_{3}-\mathrm{C}\right)$

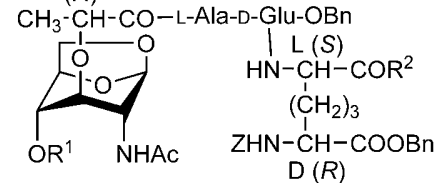

40: $\mathrm{R}^{1}=3-\mathrm{O}-\mathrm{Bn}-4,6-\mathrm{O}-$ benzylidene-GIcNAc41 (92\%): $\mathrm{R}^{1}=3-\mathrm{O}-\mathrm{Bn}-4,6-\mathrm{O}$-benzylidene-GlcNAc 34: $\mathrm{R}^{1}=\mathrm{Bn}$

$$
\begin{array}{ll}
42(85 \%): & R^{1}=3-O-B n-4,6-O-\text { benzylidene-GlcNAc, } \\
& R^{2}=O B n \\
43(95 \%): & R^{1}=B n, R^{2}=\text { D-Ala-OBn } \\
44(75 \%): & R^{1}=B n, R^{2}=O B n
\end{array}
$$

$\begin{array}{ll}\text { b) } \quad & 5 \text { (quant. from } 41 \text { ), tracheal cytotoxin (TCT) } \\ 6 \text { (quant. from } 42) \\ 7 \text { (26\% from } 43) \\ 8 \text { (53\% from } 44)\end{array}$

Scheme 6. The synthesis of tracheal cytotoxin (TCT) and other fragments: a) WSCD.HCl, HOBt, Et ${ }_{3} \mathrm{~N}, \mathrm{DMF}$; b) $\mathrm{Pd}(\mathrm{OH})_{2}, \mathrm{H}_{2}\left(20 \mathrm{~kg} \mathrm{~cm}^{-2}\right)$, THF

was $37 \%$. The obtained compound $\mathbf{3 8}$ was then treated with $\mathrm{Zn} / \mathrm{Cu}$ in THF/acetic acid/acetic anhydride to cleave the $N$ Troc groups and acetylate the liberated amino groups. Subsequent deprotection of the ester group afforded disacchride 40.

The syntheses of $\mathbf{5}$ (TCT), $\mathbf{6}, \mathbf{7}$, and $\mathbf{8}$, which contain anhydro-muramic acid are shown in Scheme 6. Monosaccharide 34 and disaccharide 40 were condensed with tripeptide 28 and tetrapeptide $\mathbf{3 0}$ independently, by using WSCI. $\mathrm{HCl}$, HOBt, and triethylamine to give protected disaccharide tetrapeptide 41 (92\%), disaccharide tripeptide $\mathbf{4 2}$ (85\%), monosaccharide teterapeptide $\mathbf{4 3}$ (95\%), and monosaccharide tripeptide 44 (75\%). All benzyl and benzyloxycarbonyl groups of $41,42,43$, and 44 were removed by catalytic hydrogenation with $\mathrm{Pd}(\mathrm{OH})_{2}$ and $\mathrm{H}_{2}$ to give $\mathbf{5}$ (TCT), $\mathbf{6}, \mathbf{7}$, and 8 , respectively. We thus achieved the first chemical synthesis of TCT.

The series of DAP-type peptidoglycan fragments were also synthesized as shown in Schemes 7 and 8. The monosaccharide fragments $\mathbf{3}$ and $\mathbf{4}$ were synthesized from $\mathbf{4 5}^{[15]}$ (Scheme 7). The isomerization of the allyl group of $\mathbf{4 5}$ to a vinyl group was performed with $\mathrm{H}_{2}$-activated [ $\operatorname{Ir}(\mathrm{cod})$ $\left.\left(\mathrm{MePh}_{2} \mathrm{P}\right)_{2}\right] \mathrm{PF}_{6}(\mathrm{cod}=1,5$-cyclooctadiene $)$ to give compound 46. ${ }^{[15,46]}$ The ethyl ester of $\mathbf{4 6}$ was cleaved with $\mathrm{LiOH}$ in 1,4dioxane $/ \mathrm{THF} / \mathrm{H}_{2} \mathrm{O}$ 2:4:1, and tripeptide $\mathbf{2 8}$ or tetrapeptide 30 was subsequently introduced to the liberated carboxylic acid by using WSCD$\cdot \mathrm{HCl}, \mathrm{HOBt}$, and triethylamine, to give 48 and 49, respectively. The cleavage of the vinyl group with iodine and water gave $\mathbf{5 0}$ and $\mathbf{5 1} \cdot{ }^{[47]}$ All remaining protecting groups, the benzyl groups in the peptide moiety, and the benzylidene group at the 4,6-position of the glycan, were cleaved by hydrogenation using $\mathrm{Pd}(\mathrm{OH})_{2}$ catalysis to give compounds 3 and 4 .

Disaccharide tetrapeptide $\mathbf{1}$ and disaccharide tripeptide $\mathbf{2}$ were then synthesized from $\mathbf{5 2}^{[15,16]}$ (Scheme 8), in a similar manner as used for the monosaccharides 3 and 4 . First, 53 was obtained by deprotection of the $N$-Troc groups of $\mathbf{5 2}$ and subsequent one-pot acetylation of the liberated amino groups with $\mathrm{Zn} / \mathrm{Cu}$ in $\mathrm{THF} / \mathrm{AcOH} / \mathrm{Ac}_{2} \mathrm{O}$. Isomerization of
(Figures 1 and 2). First, the anhydro-muramic acid containing compounds 5 (TCT) and 6 (DS(anh)-3P $\mathrm{DAP}_{\mathrm{DAP}}$ were examined in comparison with shorter Nod1 ligands, A-iE-DAP (L-Alanyl- $\gamma$-D-glutaminyl-diaminopimelic acid) ${ }^{[14]}$ as shown in Figure 1.

In these compounds, 5 (TCT) showed only very weak human-Nod1 stimulatory activity. These data are consistent with a report that utilized TCT from a natural source. ${ }^{[2]}$ On the other hand, 6 (DS(anh)-3 $\mathrm{P}_{\mathrm{DAP}}$ ) showed approximately 10 -fold higher activity than that of A-iE-DAP. This demonstrated that the difference of one $\mathrm{D}$-alanine residue attached to DAP has a strong affect on recognition by human Nod1.
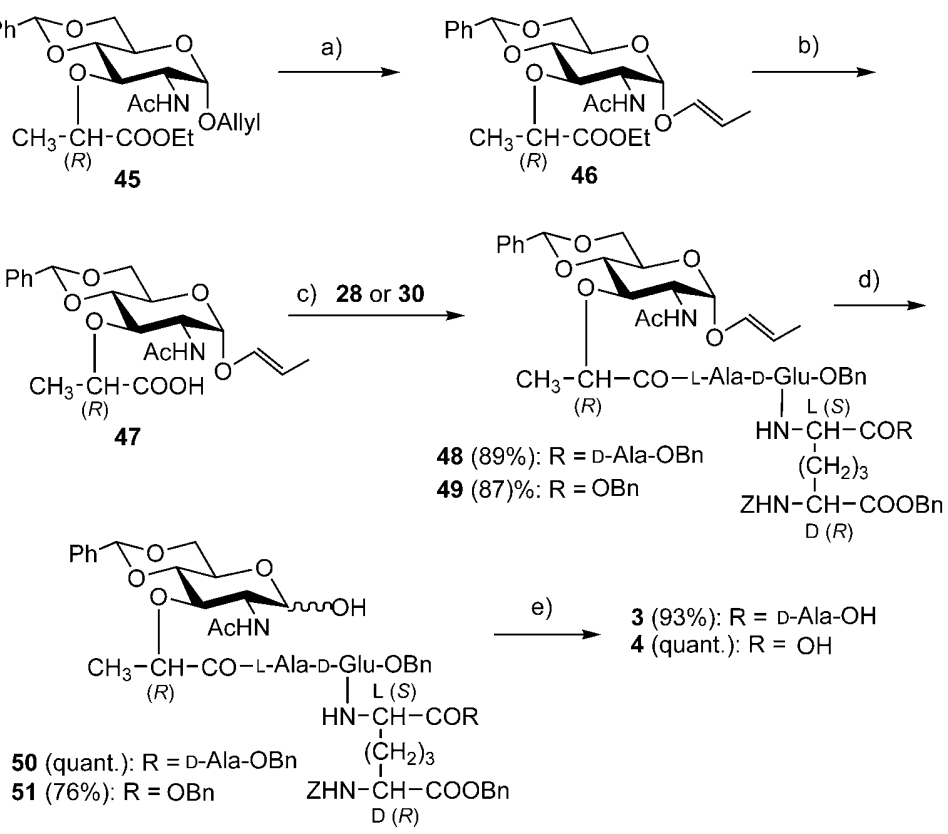

Scheme 7. Synthesis of monosaccharide-tetrapeptide $\mathbf{3}$ and -tripeptide $\mathbf{4}$ : a) $\left[\operatorname{Ir}(\operatorname{cod})(\mathrm{H})\left(\mathrm{MePh}_{2} \mathrm{P}\right)_{2}\right] \mathrm{PF}_{6}, \mathrm{THF}, 91 \%$; b) LiOH, THF/1,4-dioxane/ $\mathrm{H}_{2} \mathrm{O}$ 4:2:1, quant.; c) WSCD.HCl, HOBt, $\mathrm{Et}_{3} \mathrm{~N}, \mathrm{DMF}$; d) $\mathrm{I}_{2}, \mathrm{THF} / \mathrm{H}_{2} \mathrm{O}$ $1: 1$; e) $\mathrm{Pd}(\mathrm{OH})_{2}, \mathrm{H}_{2}\left(20 \mathrm{~kg} \mathrm{~cm}^{-2}\right)$, AcOH. 

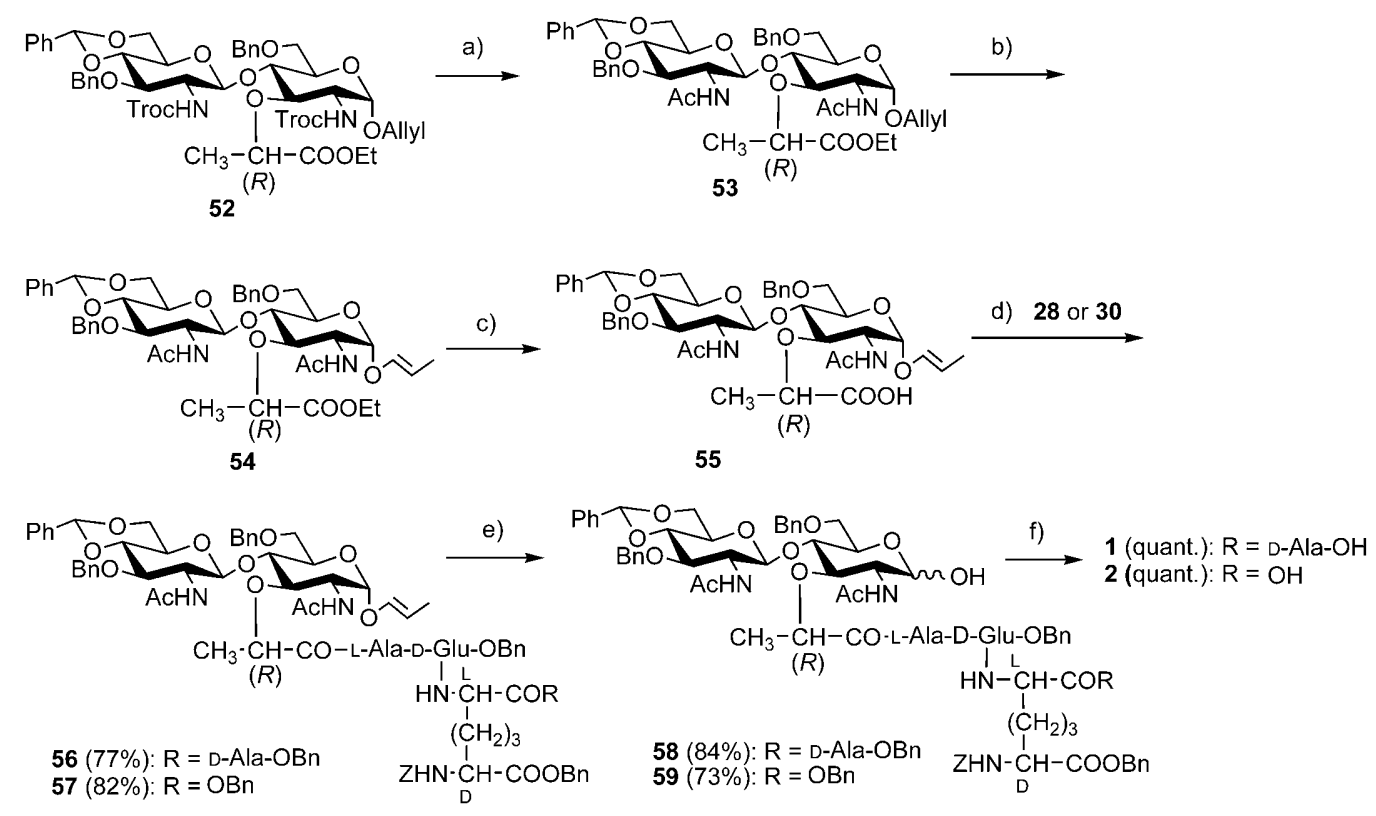

Scheme 8. Synthesis of a DAP-type PGN repeating unit 1 and the fragments 2: a) $\mathrm{Zn} / \mathrm{Cu}, \mathrm{THF} / \mathrm{AcOH} / \mathrm{Ac}_{2} \mathrm{O} 1: 1: 1,46 \%$; b) $\left[\operatorname{Ir}(\operatorname{cod})(\mathrm{H})\left(\mathrm{MePh}{ }_{2} \mathrm{P}\right)_{2}\right] \mathrm{PF}{ }_{6}$, THF, 80\%; c) LiOH, THF/1,4-dioxane/ $\mathrm{H}_{2} \mathrm{O} 4: 2: 1$; d) WSCD.HCl, HOBt, Et ${ }_{3} \mathrm{~N}, \mathrm{DMF}$; e) $\left.\mathrm{I}_{2}, \mathrm{THF} / \mathrm{H}_{2} \mathrm{O} 1: 1 ; \mathrm{f}\right) \mathrm{H}_{2}\left(20 \mathrm{~kg} \mathrm{~cm}{ }^{-2}\right), \mathrm{Pd}(\mathrm{OH})_{2}, \mathrm{AcOH}$.

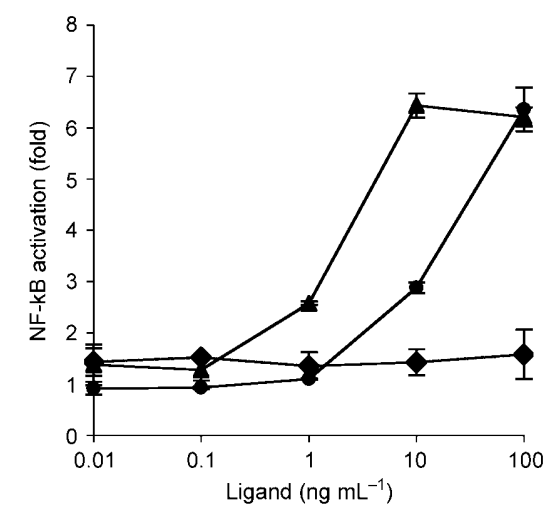

Figure 1. Stimulation of Nod1 by PG fragments, A-iE-DAP (L-Alanyl- $\gamma-$ D-glutamyl-diaminopimelic acid), 5 (TCT), and 6 (DS(anh)-3P $\mathrm{DAP}_{\mathrm{DP}}$ ). HEK293T cells were transfected with human-Nod1, and the indicated amount of each compound was added to the cells and the ability of each compound to activate NF- $\kappa \mathrm{B}$ was determined by luciferase reporter assay. ${ }^{[7]} \boldsymbol{\Lambda}: \mathbf{6}, \bullet:$ TCT (5) •: A-iE-DAP.

A free carboxyl group at the 2-position of DAP is, therefore, favorable for the receptor recognition.

We then examined the Nod1 stimulatory activity of the

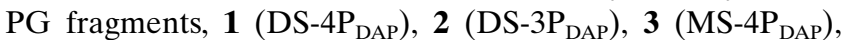
and 4 (MS-3 $\left.\mathrm{P}_{\mathrm{DAP}}\right)$, in comparison with the anhydroMurNAc-containing 6 (DS(anh)-3P $\left.\mathrm{DAP}_{\mathrm{P}}\right), \mathrm{A}-\mathrm{iE}-\mathrm{DAP}$, and a known potent ligand, C14-iE-DAP (KF1B; $N$-myristoyl-iEDAP; ${ }^{[14]}$ Figure 2). This also showed similar tendencies to the activity determined by peptide structure, with tripeptide compounds ( 2 and $\mathbf{4}$ ) being stronger human Nod1 stimulators than tetrapeptide compounds (1 and $\mathbf{3})$. Among these fragments, 4 (MS-3P $\mathrm{PAP}_{\mathrm{DA}}$ ) showed the most potent activity, which was similar to that of $6\left(\mathrm{DS}(\mathrm{anh})-3 \mathrm{P}_{\mathrm{DAP}}\right)$ and $\mathrm{C} 14-\mathrm{iE}-$

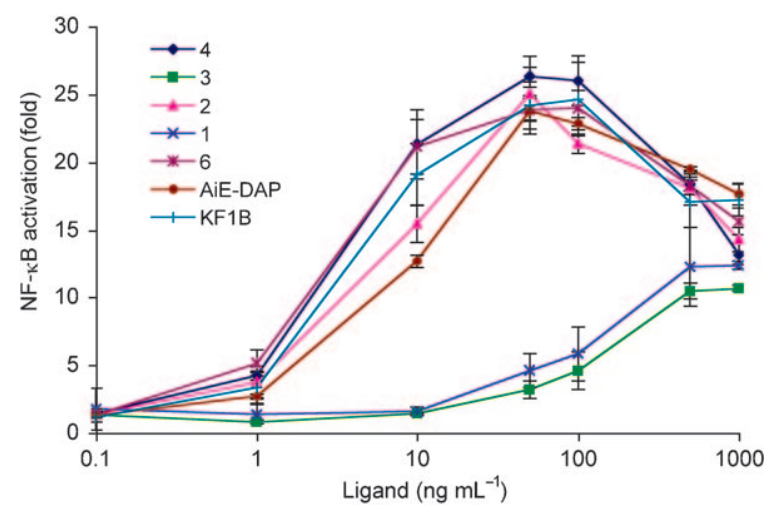

Figure 2. Stimulation of Nod1 by PG fragments, A-iE-DAP(L-Alanyl- $\gamma$-Dglutamyl-diaminopimelic acid), C14-iE-DAP (KF1B; $N$ - myristoyl-iEDAP), 1 (DS-4P $\left.\mathrm{P}_{\mathrm{DAP}}\right), 2\left(\mathrm{DS}-3 \mathrm{P}_{\mathrm{DAP}}\right), \mathbf{3}\left(\mathrm{MS}-4 \mathrm{P}_{\mathrm{DAP}}\right), \mathbf{4}\left(\mathrm{MS}-3 \mathrm{P}_{\mathrm{DAP}}\right)$, and 6 (DS(anh)-3P $\left.\mathrm{PAP}_{\mathrm{DA}}\right)$. HEK293T cells were transfected with human-Nod1, and the indicated amount of each compound was added to the cells and the ability of each compound to activate NF- $\kappa \mathrm{B}$ was determined by luciferase reporter assay. ${ }^{[7]}$

DAP (KF1B). These results suggested that the substitution of the N-terminus of iE-DAP is necessary for stronger Nod1 recognition, but the structure of the substituent seems not to be strictly recognized. The importance of the carboxyl group at the 2-position of DAP for the Nod1 stimulation is also shown by these results. It has previously been observed that 3 (MS-4 $\left.\mathrm{P}_{\mathrm{DAP}}\right)$ and 4 (MS-3P $\left.\mathrm{P}_{\mathrm{DAP}}\right)$ showed similar activities in the human Nod1 stimulation at a higher concentration $(5 \mu \mathrm{M}) \cdot{ }^{[48]}$ Although we also observed that 3 (MS-4P $\left.\mathrm{PAP}_{\text {DP }}\right)$ and $4\left(\mathrm{MS}-3 \mathrm{P}_{\mathrm{DAP}}\right)$ showed similar stimulatory activities at a higher concentrations, such as $1000 \mathrm{ng} \mathrm{mL}^{-1}(1.4-1.6 \mu \mathrm{M})$, de- 
tailed Nod1 stimulatory activities were observed at relatively lower doses from 0.1 to $100 \mathrm{ng} \mathrm{mL}^{-1}$ in this study.

\section{Conclusion}

As described, we have developed a new method for the preparation of orthogonally protected meso-DAP, and achieved the first chemical synthesis of TCT and the repeatingunit of DAP-type PGN, and various other DAP-type PGN partial structures, to investigate the PGN-receptor recognition. We determined human Nod1 stimulatory activities with these synthetic fragments. The results demonstrated that the free carboxyl group at the 2-position of DAP is important for human Nod1 stimulation, and that substitution of the $\mathrm{N}$ terminus of iE-DAP is recognized by Nod1, although this seems not to be a strict recognition. TCT only weakly stimulates human Nod1, but it has been reported that TCT has a key role in innate immune systems of other species. ${ }^{[22,23]}$ One of these examples is the activation of PGRP-LC in Drosophila ${ }^{[22,23]}$ which is a trigger for its innate immune response against Gram-negative bacteria. It was also recently shown that recognition of DAP-type PGN by PGRP-LE in Drosophila was crucial for the induction of autophagy, which prevented the intracellular growth of Listeria monocytogenes and promoted host survival after the infection. ${ }^{[49]}$ The structurally defined synthesized PGN fragments should contribute to further understanding of the mechanism of PGN action in the immune system.

\section{Experimental Section}

General procedures: ${ }^{1} \mathrm{H}$ NMR spectra were recorded at $400 \mathrm{MHz}$ by using a JEOL JMN-GSX 400 spectrometer and at $500 \mathrm{MHz}$ by using a JEOL JNM-LA 500 spectrometer. The chemical shifts in $\mathrm{CDCl}_{3}$ are given in $\delta$ values from tetramethylsilane as an internal standard. For the measurement in $\mathrm{D}_{2} \mathrm{O}$, the HDO signal $\left(\delta=4.718 \mathrm{ppm}\right.$ at $\left.30^{\circ} \mathrm{C}\right)$ was used as a reference. ESI-TOF mass spectrometry was carried out by using an Applied Biosystem Mariner Biospectrometry Workstation. ESI-QTOF mass spectrometry was carried out by using a Waters-Micromass Q-Tof micro. Elemental analyses were performed with Yanaco CHN corder MT-6. Silica-gel column chromatography was carried out by using Kieselgel 60 (Merck, $0.040-0.063 \mathrm{~mm}$ ) at medium pressure $\left(2-4 \mathrm{~kg} \mathrm{~cm}^{-2}\right)$. HPLC analysis was carried out with CHROMATOPAC C-R7A plus and LCsolution by SHIMADZU CORPORATION. Anhydrous $\mathrm{CH}_{2} \mathrm{Cl}_{2}$ was prepared by distillation from calcium hydride. Molecular sieves $4 \AA$ were activated in vacuo at $250^{\circ} \mathrm{C}$ for $3 \mathrm{~h}$ before use. All other reagents and solvents used were purchased from commercial sources.

1-[(4R)-2,2-Dimethyl-3- $N$-benzyloxycarbonyloxazolidin-4-yl]-3-[(4S)-2,2dimethyl-3- $N$-tert-butyloxycarbonyloxazolidin-4-yl]-1-propene (11): NaHMDS (7.7 mL, $1.0 \mathrm{~m}$ in THF) was added dropwise to a solution of $\mathbf{1 0}$ $(2.7 \mathrm{~g}, 5.90 \mathrm{mmol})$ in dry THF $(50 \mathrm{~mL})$ at $-70^{\circ} \mathrm{C}$. Then aldehyde $9(1.4 \mathrm{~g}$, $5.90 \mathrm{mmol})$ in dry THF $(10 \mathrm{~mL})$ was added, and the resulting mixture was stirred for $2 \mathrm{~h}$ at RT. After this time, the reaction was extracted with $\mathrm{Et}_{2} \mathrm{O}$. The organic layer was washed with brine, dried over $\mathrm{Na}_{2} \mathrm{SO}_{4}$, and then concentrated in vacuo. The residue was purified by silica-gel flash chromatography $(150 \mathrm{~g}$, toluene/AcOEt $15: 1)$ to give $\mathbf{1 1}(2.1 \mathrm{~g}, 75 \%)$. ${ }^{1} \mathrm{H}$ NMR $\left(500 \mathrm{MHz}, \mathrm{CDCl}_{3}\right): \delta=7.40-7.28\left(5 \mathrm{H}, \mathrm{m} ; \mathrm{C}_{6} H_{5}-\right), 5.56-5.38$ $(2 \mathrm{H}, \mathrm{m} ;-\mathrm{CH}=\mathrm{CH}-), 5.09\left(2 \mathrm{H}, \mathrm{brs} ;-\mathrm{CH}_{2}-\mathrm{Ph}\right), 4.11-4.05\left(1 \mathrm{H}, \mathrm{m} ; \mathrm{C}=\mathrm{C}^{-}\right.$ $\mathrm{CH}-)$, 3.90-3.57 $\left(5 \mathrm{H}, \mathrm{m} ;-\mathrm{CH}-\mathrm{CH}_{2}-\mathrm{C}=\mathrm{C}-,-\mathrm{O}-\mathrm{CH}_{2}-\mathrm{CH}-\times 2\right), 2.53-$ $1.96\left(2 \mathrm{H}, \mathrm{m} ;-\mathrm{CH}_{2}-\mathrm{C}=\mathrm{C}-\right), 1.63-1.48 \mathrm{ppm}\left(7 \mathrm{H}, \mathrm{m} ; \mathrm{CH}_{3}-\times 7\right)$; elemental analysis calcd (\%) for $\mathrm{C}_{26} \mathrm{H}_{38} \mathrm{~N}_{2} \mathrm{O}_{6} \cdot 0.9 \mathrm{H}_{2} \mathrm{O}$ : C 63.63, H 8.17, N 5.71; found: C 63.28, H 7.91, N 6.18; ESI-TOF-MS (positive): $\mathrm{m} / z$ : 475.1 $[M+\mathrm{H}]^{+}$.

(2R,6S)-2-(Benzyloxycarbonylamino)-6-(tert-butyloxycarbonylamino)hept-3-ene-1,7-diol (14): $p$ TsOH $\cdot \mathrm{H}_{2} \mathrm{O}(2 \mathrm{~g}, 0.011 \mathrm{~mol})$ was added to a solution of $\mathbf{1 1}(2.4 \mathrm{~g}, 5.05 \mathrm{mmol})$ in $\mathrm{MeOH}$, and the resulting mixture was stirred for $3 \mathrm{~h}$. After this time, saturated $\mathrm{NaHCO}_{3}$ aq. was added to bring the mixture to $\mathrm{pH} 8$ and then $\mathrm{Boc}_{2} \mathrm{O}(1.2 \mathrm{~mL}, 5.05 \mathrm{mmol})$ was added. After the mixture had been stirred for $5 \mathrm{~h}$, it was extracted with $\mathrm{CHCl}_{3}$. The organic layer was washed with brine, dried over $\mathrm{Na}_{2} \mathrm{SO}_{4}$, and then concentrated in vacuo. The residue was purified by silica-gel flash chromatography $\left(150 \mathrm{~g}, \mathrm{CHCl}_{3} /\right.$ acetone $\left.5: 1\right)$ to give $\mathbf{1 4}(1.7 \mathrm{~g}, 89 \%) .{ }^{1} \mathrm{H}$ NMR $\left(500 \mathrm{MHz}, \mathrm{CDCl}_{3}\right): \delta=7.37-7.29\left(5 \mathrm{H}, \mathrm{m} ; \mathrm{C}_{6} H_{5}-\right), 5.54(1 \mathrm{H}, \mathrm{td}, J=10$, $\left.5 \mathrm{~Hz} ;-\mathrm{CH}_{2}-\mathrm{CH}=\mathrm{CH}-, c i s\right), 5.40\left(1 \mathrm{H}, \mathrm{t}, J=10 \mathrm{~Hz} ;-\mathrm{CH}_{2}-\mathrm{CH}=\mathrm{CH}-\right.$, cis), $5.11\left(1 \mathrm{H}, \mathrm{d}, J=12 \mathrm{~Hz} ; \mathrm{C}_{6} \mathrm{H}_{5}-\mathrm{CH}_{2}-\right), 5.05\left(1 \mathrm{H}, \mathrm{d}, J=12 \mathrm{~Hz} ; \mathrm{C}_{6} \mathrm{H}_{5}-\right.$ $\left.\mathrm{CH}_{2}-\right), 4.54\left(1 \mathrm{H}\right.$, brs; $\left.-\mathrm{HN}-\mathrm{CH}-\mathrm{CH}_{2}-\right), 3.67-3.59\left(4 \mathrm{H}, \mathrm{m} ;-\mathrm{CH}_{2} \mathrm{OH}\right.$ $\times 2), 3.55-3.53(1 \mathrm{H}, \mathrm{m} ;=\mathrm{CH}-\mathrm{CH}-), 2.29-2.24\left(2 \mathrm{H}, \mathrm{m} ;-\mathrm{CH}_{2}-\mathrm{CH}=\right)$, 2.14-1.62 $\left(2 \mathrm{H}, \mathrm{m} ;-\mathrm{CH}_{2} \mathrm{OH} \times 2\right), 1.44 \mathrm{ppm}\left(9 \mathrm{H}, \mathrm{s} ;\left(\mathrm{CH}_{3}\right)_{3} \mathrm{C}-\right)$; elemental analysis calcd (\%) for $\mathrm{C}_{20} \mathrm{H}_{30} \mathrm{~N}_{2} \mathrm{O}_{6}$ : C 60.90, H 7.67, N 7.10; found: $\mathrm{C}$ 63.28, H 7.91, N 6.18; ESI-TOF-MS (positive): $m / z: 395.2[M+\mathrm{H}]^{+}$.

(2S,6R)-6-(Benzyloxycarbonylamino)-2-(tert-butyloxycarbonylamino)heptane-1,7-diol: Compound $14(1.57 \mathrm{~g}, 3.99 \mathrm{mmol})$ was dissolved in THF $(40 \mathrm{~mL})$ and $\mathrm{Pd} / \mathrm{C}(1.5 \mathrm{~g})$ was added to the resulting solution. The reaction was stirred for 1 day under a $\mathrm{H}_{2}$ atmosphere. After this time, $\mathrm{Pd}$ $\mathrm{C}$ was removed by membrane filtration and the solution was concentrated in vacuo. The residue was dissolved in 1,4-dioxane $(20 \mathrm{~mL})$ at $0{ }^{\circ} \mathrm{C}$ and then $\mathrm{NaHCO}_{3}$ aq. $(1.3 \mathrm{~g}, 0.016 \mathrm{~mol}, 20 \mathrm{~mL})$ and $\mathrm{ZCl}(855 \mu \mathrm{L}$, $5.99 \mathrm{~mol}$ ) were added. The mixture was stirred for $30 \mathrm{~min}$ at RT. After this time, the reaction mixture was extracted with AcOEt. The organic layer was washed with saturated $\mathrm{NaHCO}_{3}$ aq. and brine, dried over $\mathrm{Na}_{2} \mathrm{SO}_{4}$, and then concentrated in vacuo. The residue was recrystallized by $\mathrm{CHCl}_{3}$ /hexane to give $\mathbf{1 5}(869 \mathrm{mg}, 58 \%) .{ }^{1} \mathrm{H} \mathrm{NMR}\left(500 \mathrm{MHz}, \mathrm{CDCl}_{3}\right)$ $\delta=7.38-7.29\left(5 \mathrm{H}, \mathrm{m} ; \mathrm{C}_{6} \mathrm{H}_{5}-\right), 5.10\left(2 \mathrm{H}, \mathrm{s} ; \mathrm{C}_{6} \mathrm{H}_{5}-\mathrm{CH}_{2}-\right), 3.72-3.3 .61$ $\left(4 \mathrm{H}, \mathrm{m} ;-\mathrm{CH}_{2} \mathrm{OH} \times 2\right), 3.54-3.52(2 \mathrm{H}, \mathrm{m} ; \alpha \mathrm{H} \times 2), 2.03(2 \mathrm{H}, \mathrm{m}$ $\left.-\mathrm{CH}_{2} \mathrm{OH} \times 2\right), 1.64-1.56\left(4 \mathrm{H}, \mathrm{m} ;-\mathrm{CH}-\mathrm{CH}_{2}-\mathrm{CH}_{2}-\times 2\right), 1.44(9 \mathrm{H}, \mathrm{s}$; $\left.\left(\mathrm{CH}_{3}\right)_{3} \mathrm{C}-\right), 1.33-1.23 \mathrm{ppm}\left(2 \mathrm{H}, \mathrm{m}\right.$; $\left.-\mathrm{CH}_{2}-\mathrm{CH}_{2}-\mathrm{CH}_{2}-\right)$; elemental analysis calcd (\%) for $\mathrm{C}_{20} \mathrm{H}_{32} \mathrm{~N}_{2} \mathrm{O}_{6}: \mathrm{C} 60.59, \mathrm{H} 8.14, \mathrm{~N}$ 7.07; found: $\mathrm{C} 60.51, \mathrm{H}$ 8.02, N 7.12; ESI-TOF-MS (positive): $m / z: 397.3[M+\mathrm{H}]^{+}$.

Dibenzyl (2S,6R)-6-(benzyloxycarbonylamino)-2-(tert-butyloxycarbonylamino)heptanedioate (17): Compound 15 (420 mg, $1.06 \mathrm{mmol})$, PDC (4 g, $0.011 \mathrm{~mol})$, and Celite $(4 \mathrm{~g})$ were added to dry DMF $(15 \mathrm{~mL})$, and the resulting mixture was stirred for 1 day. After this time, the mixture was filtrated through Celite, and the filtrate was extracted with $\mathrm{Et}_{2} \mathrm{O}$. The organic layer was washed with $10 \%$ citric acid solution, dried over $\mathrm{Na}_{2} \mathrm{SO}_{4}$, and then concentrated in vacuo. The residue and $\mathrm{Cs}_{2} \mathrm{CO}_{3}(363 \mathrm{mg}$, $1.11 \mathrm{mmol})$ were dissolved in $\mathrm{MeOH}(5 \mathrm{~mL})$ and the solution was concentrated in vacuo. The residue was dissolved in dry DMF $(10 \mathrm{~mL})$ and then $\mathrm{BnBr}(265 \mu \mathrm{L}, 2.23 \mathrm{mmol})$ was added under an $\mathrm{Ar}$ atmosphere. After the reaction had been stirred for 1 day, it was extracted with AcOEt. The organic layer was washed with brine, dried over $\mathrm{Na}_{2} \mathrm{SO}_{4}$, and then concentrated in vacuo. The residue was purified by silica-gel flash chromatography $(40 \mathrm{~g}$, toluene/AcOEt $8: 1)$ to give $17(475 \mathrm{mg}$, $74 \%) .{ }^{1} \mathrm{H}$ NMR $\left(500 \mathrm{MHz}, \mathrm{CDCl}_{3}\right): \delta=7.35-7.28\left(5 \mathrm{H}, \mathrm{m} ; \mathrm{C}_{6} \mathrm{H}_{5}-\right), 5.28$ $(1 \mathrm{H}$, brs; $\mathrm{NH}), 5.17-5.07\left(6 \mathrm{H}, \mathrm{m} ;-\mathrm{CH}_{2}-\mathrm{Ph} \times 3\right), 4.98(1 \mathrm{H}, \mathrm{brs} ; \mathrm{NH})$ $4.36(1 \mathrm{H}, \mathrm{d}, J=5 \mathrm{~Hz} ; \alpha \mathrm{H}), 4.28(1 \mathrm{H}, \mathrm{d}, J=4 \mathrm{~Hz} ; \alpha \mathrm{H}), 1.56-1.26(6 \mathrm{H}, \mathrm{m}$; $\left.-\left(\mathrm{CH}_{2}\right)_{3}-\right), 1.42 \mathrm{ppm}\left(9 \mathrm{H}, \mathrm{s} ;-\mathrm{C}\left(\mathrm{CH}_{3}\right)_{3}\right)$; elemental analysis calcd $(\%)$ for $\mathrm{C}_{34} \mathrm{H}_{40} \mathrm{~N}_{2} \mathrm{O}_{8} \cdot 0.3 \mathrm{H}_{2} \mathrm{O}$ : C 66.94, H 6.71, N 4.59; found: $\mathrm{C} 66.95, \mathrm{H} 6.60$, N 4.45; HPLC analysis: (Daicel CHIRAL PAK AD-H, $0.46 \times 25 \mathrm{~cm}$, $1 \mathrm{~mL} \mathrm{~min}^{-1}$, hexane/2-propanol 7:3): $254 \mathrm{~nm}$; ESI-TOF-MS (positive) $m / z: 605.3[M+\mathrm{H}]^{+}$.

(4S)-4-[(4R)-4-(Benzyloxycarbonyamino)-5-hydroxy-2-pentenyl]oxazolidine-2-one (18): Compound $11(700 \mathrm{mg}, 1.48 \mathrm{mmol})$ was dissolved in $\mathrm{MeOH}(9 \mathrm{~mL})$ and added to $4 \mathrm{~N} \mathrm{HCl}$ in 1,4-dioxane $(3 \mathrm{~mL})$. After the reaction mixture had been stirred for $1.5 \mathrm{~h}$, it was concentrated in vacuo The residue was dissolved in dry $\mathrm{CH}_{2} \mathrm{Cl}_{2}(14 \mathrm{~mL})$ at $0^{\circ} \mathrm{C}$, and then $\mathrm{Et}_{3} \mathrm{~N}$ $(1 \mathrm{~mL}, 7.40 \mathrm{mmol})$ was added. A solution of triphosgene $(158 \mathrm{mg}$, $0.53 \mathrm{mmol})$ in $\mathrm{CH}_{2} \mathrm{Cl}_{2}(7 \mathrm{~mL})$ was added to the mixture, and it was stirred for a further $1 \mathrm{~h}$. After this time, the reaction mixture was quenched by 
saturated $\mathrm{NaHCO}_{3}$ aq. The organic layer was washed with saturated $\mathrm{NaHCO}_{3}$ aq., dried over $\mathrm{Na}_{2} \mathrm{SO}_{4}$, and then concentrated in vacuo. The residue was purified by silica-gel flash chromatography $\left(50 \mathrm{~g}, \mathrm{CHCl}_{3} /\right.$ acetone $2: 1)$ to give $18(387 \mathrm{mg}, 82 \%) .{ }^{1} \mathrm{H} \mathrm{NMR}\left(500 \mathrm{MHz}, \mathrm{CDCl}_{3}\right): \delta=$ 7.37-7.27 (5 H, m; $\left.\mathrm{C}_{6} \mathrm{H}_{5}-\right)$, 5.61-5.51 $(2 \mathrm{H}, \mathrm{m} ;-\mathrm{CH}=\mathrm{CH}-), 5.13-5.06$ $\left(2 \mathrm{H}, \mathrm{s} ;-\mathrm{CH}_{2}-\mathrm{Ph}\right), 4.59-4.44\left(2 \mathrm{H}, \mathrm{m} ;-\mathrm{C}=\mathrm{C}-\mathrm{CH}-,-\mathrm{C}(\mathrm{O}) \mathrm{O}-\mathrm{CH}_{2}-\mathrm{CH}-\right)$, 4.02-3.99 $\left(1 \mathrm{H}, \mathrm{m} ;-\mathrm{C}(\mathrm{O}) \mathrm{O}-\mathrm{CH}_{2}-\mathrm{CH}-\right), 3.89\left(1 \mathrm{H}\right.$, brs; $\mathrm{C}(\mathrm{O}) \mathrm{O}-\mathrm{CH}_{2}-$ $\mathrm{CH}-)$, 3.73-3.65 $\left(2 \mathrm{H}, \mathrm{m} ;-\mathrm{CH}_{2} \mathrm{OH}\right), 2.24-2.16 \mathrm{ppm}\left(2 \mathrm{H}, \mathrm{m} ;-\mathrm{CH}_{2}-\mathrm{C}=\right.$ C); elemental analysis calcd (\%) for $\mathrm{C}_{16} \mathrm{H}_{20} \mathrm{~N}_{2} \mathrm{O}_{5} \cdot 0.51$, 4-dioxane $\cdot 0.5 \mathrm{H}_{2} \mathrm{O}$ : C 57.90, H 6.75, N 7.50; found: C 57.87, H 6.62, N 7.43; ESI-TOF-MS (positive): $m / z: 321.2[M+\mathrm{H}]^{+}$

(4S)-4-[(4R)-4-(Benzyloxycarbonyamino)-5-hydroxypentyl]oxazolidine-2one (19): Compound 18 (123 mg, $0.384 \mathrm{mmol})$ was dissolved in $\mathrm{MeOH}$ $(4 \mathrm{~mL})$ and $\mathrm{Pd} / \mathrm{C}(120 \mathrm{mg})$ was added to the resulting solution. The reaction mixture was stirred for 1 day under a $\mathrm{H}_{2}$ atmosphere. $\mathrm{Pd} / \mathrm{C}$ was removed by membrane filtration and the solution was concentrated in vacuo. The residue was dissolved in 1,4-dioxane $(2 \mathrm{~mL})$, and then $\mathrm{ZCl}$ $(82 \mu \mathrm{L}, 0.576 \mathrm{mmol})$ and $\mathrm{NaHCO}_{3}$ aq. $(129 \mathrm{mg}, 1.54 \mathrm{mmol}, 12 \mathrm{~mL})$ were added. The reaction mixture was stirred for $1.5 \mathrm{~h}$. After this time, the reaction was extracted with $\mathrm{CHCl}_{3}$. The organic layer was washed with saturated $\mathrm{NaHCO}_{3}$ aq. and brine, dried over $\mathrm{Na}_{2} \mathrm{SO}_{4}$, and then concentrated in vacuo. The residue was purified by silica-gel flash chromatography (7 g, $\mathrm{CHCl}_{3} /$ acetone $\left.2: 1\right)$ to give $19(97 \mathrm{mg}, 79 \%) .{ }^{1} \mathrm{H} \mathrm{NMR}(500 \mathrm{MHz}$, $\left.\mathrm{CDCl}_{3}\right): \delta=7.35-7.28\left(5 \mathrm{H}, \mathrm{m} ; \mathrm{C}_{6} \mathrm{H}_{5}-\right), 5.09\left(2 \mathrm{H}, \mathrm{s} ;-\mathrm{CH}_{2}-\mathrm{Ph}\right), 4.44(1 \mathrm{H}$, $\left.\mathrm{m} ;-\mathrm{C}(\mathrm{O}) \mathrm{O}-\mathrm{CH}_{2}-\mathrm{CH}-\right), 3.96\left(1 \mathrm{H}, \mathrm{m} ;-\mathrm{C}(\mathrm{O}) \mathrm{O}-\mathrm{CH}_{2}-\mathrm{CH}-\right), 3.84(1 \mathrm{H}$, brs; $\left.\mathrm{C}(\mathrm{O}) \mathrm{O}-\mathrm{CH}_{2}-\mathrm{CH}-\right), \quad 3.65-3.63\left(3 \mathrm{H}, \quad \mathrm{m} ;-\mathrm{CH}-\mathrm{CH}_{2} \mathrm{OH}\right), \quad 1.60$ $1.25 \mathrm{ppm}\left(6 \mathrm{H}, \mathrm{m}\right.$; $\left.-\mathrm{CH}_{2} \mathrm{CH}_{2} \mathrm{CH}_{2}-\right)$; elemental analysis calcd (\%) for $\mathrm{C}_{16} \mathrm{H}_{22} \mathrm{~N}_{2} \mathrm{O}_{5} \cdot 0.41$,4-dioxane $\cdot 0.2 \mathrm{H}_{2} \mathrm{O}$ : C 58.52, $\mathrm{H} 7.14, \mathrm{~N} 7.76$; found: $\mathrm{C}$ 58.50, H 7.14, N 7.83; ESI-TOF-MS (positive): $m / z: 323.2[M+\mathrm{H}]^{+}$

(4S)-4-[(4R)-4-(Benzyloxycarbonyamino)-4-(carboxy)pentyl] oxazolidine2-one (20): $\quad \mathrm{RuCl}_{3} \cdot n \mathrm{H}_{2} \mathrm{O} \quad(56 \mathrm{mg}, \quad 0.27 \mathrm{mmol})$ and $\mathrm{NaIO}_{4} \quad(1.9 \mathrm{~g}$, $8.98 \mathrm{mmol})$ were dissolved in acetone $(3 \mathrm{~mL})$ and $\mathrm{H}_{2} \mathrm{O}(3 \mathrm{~mL})$ at $-18^{\circ} \mathrm{C}$. A solution of $19(290 \mathrm{mg}, 0.898 \mathrm{mmol})$ in acetone $(3 \mathrm{~mL})$ was then added dropwise and the reaction mixture was stirred for $20 \mathrm{~min}$ at $-18^{\circ} \mathrm{C}$. After this time, 2-propanol $(4 \mathrm{~mL})$ was added to the reaction mixture and it was stirred for a further $1 \mathrm{~h}$. Insoluble matter was removed by Celite filtration, and the filtrate was extracted with $\mathrm{CHCl}_{3}$. The organic layer was washed with $10 \%$ citric acid aq. and brine, dried over $\mathrm{Na}_{2} \mathrm{SO}_{4}$, and then concentrated in vacuo to give crude carboxylic acid $\mathbf{2 0}$

(4S)-4-[(4R)-4-(Benzyloxycarbonyamino)-4-(methyloxycarbonyl)pentyl]oxazolidine-2-one (21): $\mathrm{AcCl}(639 \mu \mathrm{L}, 8.98 \mathrm{mmol})$ was added dropwise to $\mathrm{MeOH}(6 \mathrm{~mL})$ at $0^{\circ} \mathrm{C}$. The solution was stirred for $30 \mathrm{~min}$ at RT. After this time, a solution of $\mathbf{2 0}(0.898 \mathrm{mmol})$ in $\mathrm{MeOH}(3 \mathrm{~mL})$ was added and the reaction mixture was stirred for a further $2 \mathrm{~h}$. After this time, the solution was concentrated in vacuo and the residue was purified by using a Biotage column (7 g, $\mathrm{CHCl}_{3} /$ acetone $\left.10: 1\right)$ to give 21 (284 mg, 89\%). ${ }^{1} \mathrm{H}$ NMR $\left(500 \mathrm{MHz}, \mathrm{CDCl}_{3}\right): \delta=7.35-7.28\left(5 \mathrm{H}, \mathrm{m} ; \mathrm{C}_{6} \mathrm{H}_{5}-\right), 5.09(2 \mathrm{H}, \mathrm{s}$; $\left.-\mathrm{CH}_{2}-\mathrm{Ph}\right), 4.44\left(1 \mathrm{H}, \mathrm{m} ;-\mathrm{C}(\mathrm{O}) \mathrm{O}-\mathrm{CH}_{2}-\mathrm{CH}-\right), 3.96(1 \mathrm{H}, \mathrm{m} ;-\mathrm{C}(\mathrm{O}) \mathrm{O}-$ $\left.\mathrm{CH}_{2}-\mathrm{CH}-\right), 3.84\left(1 \mathrm{H}\right.$, br s; $\left.\mathrm{C}(\mathrm{O}) \mathrm{O}-\mathrm{CH}_{2}-\mathrm{CH}-\right), 3.65-3.63(3 \mathrm{H}, \mathrm{m} ;-\mathrm{CH}-$ $\left.\mathrm{CH}_{2} \mathrm{OH}\right), 1.60-1.25 \mathrm{ppm}\left(6 \mathrm{H}, \mathrm{m} ;-\mathrm{CH}_{2} \mathrm{CH}_{2} \mathrm{CH}_{2}-\right)$; elemental analysis calcd $(\%)$ for $\mathrm{C}_{17} \mathrm{H}_{22} \mathrm{~N}_{2} \mathrm{O}_{6} \cdot 0.51$,4-dioxane $0.5 \mathrm{H}_{2} \mathrm{O}: \mathrm{C} 56.57, \mathrm{H} 6.75, \mathrm{~N}$ 6.94; found: C 56.57, H 6.63, N 6.91; ESI-TOF-MS (positive): $\mathrm{m} / \mathrm{z}: 351.19$ $[M+\mathrm{H}]^{+}$.

(4S)-4-[(4R)-4-(Benzyloxycarbonyamino)-4-(methyloxycarbonyl)pentyl]3- $\boldsymbol{N}$-tert-butoxycarbonyloxazolidine-2-one (22): Compound 21 (128 mg, $0.37 \mathrm{mmol}$ ) was dissolved in THF (4 mL). DMAP (13 mg, $0.11 \mathrm{mmol})$, triethylamine $(102 \mu \mathrm{L}, 0.73 \mathrm{mmol})$, and $\operatorname{Boc}_{2} \mathrm{O}(119 \mu \mathrm{L}, 0.55 \mathrm{mmol})$ were then added to the THF solution, and the reaction mixture was stirred for $1 \mathrm{~h}$. After this time, the reaction was extracted with $\mathrm{CHCl}_{3}$ and the resulting organic layer was washed with $10 \%$ citric acid and brine, dried over $\mathrm{Na}_{2} \mathrm{SO}_{4}$, and then concentrated in vacuo. The residue was purified by silica-gel flash chromatography (toluene/AcOEt: $3: 1$ ) to give 22 $(142 \mathrm{mg}, 86 \%) .{ }^{1} \mathrm{H} \mathrm{NMR}\left(500 \mathrm{MHz}, \mathrm{CDCl}_{3}\right): \delta=7.38-7.26(5 \mathrm{H}, \mathrm{m}$; $\left.\mathrm{C}_{6} \mathrm{H}_{5}-\right), 5.29(1 \mathrm{H}, \mathrm{d}, J=7.5 \mathrm{~Hz} ; \mathrm{NH}), 5.11\left(2 \mathrm{H}, \mathrm{s} ;-\mathrm{CH}_{2}-\mathrm{Ph}\right), 4.39-4.38$ $(1 \mathrm{H}, \mathrm{m} ;-\mathrm{CH}-\mathrm{COOMe}), 4.28\left(1 \mathrm{H}, \mathrm{t}, \mathrm{J}=8.3 \mathrm{~Hz} ;-\mathrm{CH}-\mathrm{CH}_{2}-\mathrm{O}-\right), 4.20$ $4.17\left(1 \mathrm{H}, \mathrm{m} ;-\mathrm{CH}-\mathrm{CH}_{2}-\mathrm{O}-\right), 3.97\left(1 \mathrm{H}, \mathrm{d}, \mathrm{J}=6.5 \mathrm{~Hz} ;-\mathrm{N}-\mathrm{CH}-\mathrm{CH}_{2}-\right)$, $3.74\left(3 \mathrm{H}, \mathrm{s} ; \mathrm{CH}_{3}\right), 1.91-1.83\left(2 \mathrm{H}, \mathrm{m} ;-\mathrm{CH}_{2}-\right), 1.74-1.65\left(2 \mathrm{H}, \mathrm{m} ;-\mathrm{CH}_{2}-\right)$, $1.53 \mathrm{ppm}\left(9 \mathrm{H}, \quad \mathrm{s} ;-\mathrm{C}\left(\mathrm{CH}_{3}\right)_{3}\right)$; elemental analysis calcd $(\%)$ for
$\mathrm{C}_{22} \mathrm{H}_{30} \mathrm{~N}_{2} \mathrm{O}_{8} \cdot 0.5$ dioxane $\cdot 0.15 \mathrm{H}_{2} \mathrm{O}$ : C 57.97, $\mathrm{H}$ 6.95, $\mathrm{N}$ 5.63; found: $\mathrm{C}$ 57.94, H 6.85, N 6.22; ESI-TOF-MS (positive): $m / z: 473.23[M+\mathrm{Na}]^{+}$

Benzyl (2R,6S)-2-(benzyloxycarbonylamino)-6-(tert-butoxycarbonylamino)-7-hydroxylheptanoate (24): $\mathrm{LiOH} \cdot \mathrm{H}_{2} \mathrm{O}$ aq. $(31 \mathrm{mg}, 0.74 \mathrm{mmol}, 2 \mathrm{~mL})$ was added dropwise to a solution of $22(341.6 \mathrm{mg}, 0.758 \mathrm{mmol})$ in THF $(6 \mathrm{~mL})$, and the resulting mixture was stirred for $1 \mathrm{~h}$. After this time, $\mathrm{LiOH} \cdot \mathrm{H}_{2} \mathrm{O}$ aq. $(31 \mathrm{mg}, 0.74 \mathrm{mmol}, 2 \mathrm{~mL}$ ) was again added dropwise to the reaction mixture, and it was stirred for a further $1 \mathrm{~h}$. Then, more $\mathrm{LiOH} \cdot \mathrm{H}_{2} \mathrm{O}$ aq. ( $31 \mathrm{mg}, 0.74 \mathrm{mmol}, 2 \mathrm{~mL}$ ) was added dropwise to the reaction mixture, and it was stirred for a final $1 \mathrm{~h}$. The reaction mixture was then quenched by Dowex $\mathrm{H}^{+}$. The Dowex $\mathrm{H}^{+}$was removed by filtration and the filtrate was concentrated in vacuo. The residue was freeze-dried with 1,4-dioxane to give crude $\mathbf{2 3}$, which was then dissolved in $\mathrm{MeOH}(8 \mathrm{~mL}) . \mathrm{Cs}_{2} \mathrm{CO}_{3}(148 \mathrm{mg}, 0.455 \mathrm{mmol})$ was added to the solution and it was concentrated in vacuo and then co-evaporated with toluene. The residue was dissolved in dry DMF $(8 \mathrm{~mL})$ and $\mathrm{BnBr}(108 \mu \mathrm{L}$, $0.910 \mathrm{mmol}$ ) was added to the solution. The resulting reaction mixture was stirred for 1 day under an Ar atmosphere. After this time, the reaction mixture was extracted with AcOEt and the resulting organic layer was washed with $10 \%$ citric acid aq. and brine, dried over $\mathrm{Na}_{2} \mathrm{SO}_{4}$, and then concentrated in vacuo. The residue was purified by silica-gel flash chromatography (toluene/AcOEt 2:1) to give $\mathbf{2 4}$ (313 $\mathrm{mg}, 83 \%$ ). ${ }^{1} \mathrm{H}$ NMR $\left(500 \mathrm{MHz}, \mathrm{CDCl}_{3}\right): \delta=7.38-7.29\left(10 \mathrm{H}, \mathrm{m} ; \mathrm{C}_{6} H_{5} \times 2\right), 5.40-5.39$ $\left(1 \mathrm{H}\right.$, brd; NH), $5.19\left(1 \mathrm{H}, \mathrm{d}, J=12 \mathrm{~Hz} ;-\mathrm{COOCH}_{2} \mathrm{Ph}\right), 5.14(1 \mathrm{H}, \mathrm{d}, J=$ $\left.12 \mathrm{~Hz} ;-\mathrm{COOCH}_{2} \mathrm{Ph}\right), 5.10\left(2 \mathrm{H}, \mathrm{s} ; \mathrm{NH}-\mathrm{COOCH}_{2} \mathrm{Ph}\right), 4.72(1 \mathrm{H}$, brs; $\mathrm{NH}), 4.45-4.41(1 \mathrm{H}, \mathrm{m} ;-\mathrm{CH}-\mathrm{COOBn}), 3.57-3.46(3 \mathrm{H}, \mathrm{m} ;-\mathrm{CH}-$ $\left.\mathrm{CH}_{2} \mathrm{OH}\right), 1.87-1.30\left(6 \mathrm{H}, \mathrm{m} ;-\left(\mathrm{CH}_{2}\right)_{3}-\right), 1.43 \mathrm{ppm}\left(9 \mathrm{H}, \mathrm{s} ;-\mathrm{C}\left(\mathrm{CH}_{3}\right)_{3}\right)$; elemental analysis calcd (\%) for $\mathrm{C}_{27} \mathrm{H}_{36} \mathrm{~N}_{2} \mathrm{O}_{7} \cdot 0.15 \mathrm{H}_{2} \mathrm{O}: \mathrm{C} 64.43, \mathrm{H} 7.27, \mathrm{~N}$ 5.57; found: C 64.43, H 7.27, N 5.57; ESI-TOF-MS (positive): $\mathrm{m} / z: 501.2$ $[M+\mathrm{H}]^{+}$

7-Benzyl $(2 R, 6 S)-2-N$-benzyloxycarbonyl-6- $N$-tert-butoxycarbonylaminodiaminopimelate (25): Compound $24(301 \mathrm{mg}, 0.60 \mathrm{mmol})$ and PDC $(1.1 \mathrm{~g}, 3.0 \mathrm{mmol})$ were dissolved in dry DMF $(6 \mathrm{~mL})$ and the resulting mixture was stirred for 1 day under an $\mathrm{Ar}$ atmosphere. After this time, the reaction mixture was extracted with $\mathrm{Et}_{2} \mathrm{O}$ and the resulting organic layer was washed with $10 \%$ citric acid aq. and brine, dried over $\mathrm{Na}_{2} \mathrm{SO}_{4}$, and then concentrated in vacuo. The residue was purified by silica-gel flash chromatography $\left(\mathrm{CHCl}_{3} / \mathrm{MeOH} 10: 1\right.$ and $\mathrm{CHCl}_{3} / \mathrm{MeOH} / \mathrm{AcOH}$ 5:1:0.01) to give $25(264 \mathrm{mg}, 86 \%) .{ }^{1} \mathrm{H} \mathrm{NMR}\left(500 \mathrm{MHz}, \mathrm{CDCl}_{3}\right): \delta=$ 7.34-7.27 (10H, m; ArH $\times 2), 5.42(1 \mathrm{H}$, brs; NH), $5.19(1 \mathrm{H}, \mathrm{d}, J=12 \mathrm{~Hz}$; $\left.-\mathrm{COOCH}_{2} \mathrm{Ph}\right), 5.14\left(1 \mathrm{H}, \mathrm{d}, J=12 \mathrm{~Hz} ;-\mathrm{COOCH}_{2} \mathrm{Ph}\right), 5.10(2 \mathrm{H}, \mathrm{s} ; \mathrm{NH}-$ $\left.\mathrm{COOCH}_{2} \mathrm{Ph}\right), 4.40(1 \mathrm{H}$, brs; $\alpha \mathrm{H}), 4.24(1 \mathrm{H}$, brs; $\alpha \mathrm{H}), 1.91-1.31(6 \mathrm{H}, \mathrm{m}$; $\left.-\left(\mathrm{CH}_{2}\right)_{3}-\right), 1.44 \mathrm{ppm}\left(9 \mathrm{H}, \mathrm{s} ; \mathrm{C}\left(\mathrm{CH}_{3}\right)_{3}\right)$; elemental analysis calcd $(\%)$ for $\mathrm{C}_{27} \mathrm{H}_{34} \mathrm{~N}_{2} \mathrm{O}_{8} \cdot 0.4 \mathrm{H}_{2} \mathrm{O}$ : C $62.15, \mathrm{H} 6.72$, N 5.37; found: $\mathrm{C} 62.18, \mathrm{H} 6.68, \mathrm{~N}$ 5.33; ESI-TOF-MS (positive): $m / z: 515.2[M+\mathrm{H}]^{+}$.

Protected $\gamma$-D-Glu-meso-DAP (26): Compound $17(500 \mathrm{mg}, 0.83 \mathrm{mmol})$ was dissolved in $50 \%$ TFA in $\mathrm{CH}_{2} \mathrm{Cl}_{2}(4 \mathrm{~mL})$ and the resulting reaction mixture was stirred for $10 \mathrm{~min}$. After this time, the reaction mixture was concentrated and then co-evaporated in toluene. Addition of $1 \mathrm{M} \mathrm{HCl}$ ether solution gave a white solid. The supernatant was removed by decantation to give Boc-deprotected 17. WSCD. $\mathrm{HCl}(168 \mathrm{mg}, 1.08 \mathrm{mmol})$ and triethylamine $(265 \mu \mathrm{L}, 1.90 \mathrm{mmol})$ were added to a solution of the Boc-deprotected 17, benzyl tert-butoxycarbonyl glutamate (279 $\mathrm{mg}$, $0.83 \mathrm{mmol})$, and HOBt $(146 \mathrm{mg}, 1.08 \mathrm{mmol})$ in dry THF $(8 \mathrm{~mL})$. The reaction mixture was stirred for 1 day under an $\mathrm{Ar}$ atmosphere before being extracted with AcOEt. The organic layer was washed with $10 \%$ citric acid solution, saturated aq. $\mathrm{NaHCO}_{3}$, and brine, dried over $\mathrm{Na}_{2} \mathrm{SO}_{4}$ and then concentrated in vacuo. The residue was purified by silica-gel flash column chromatography (toluene/AcOEt 3:1) to give 26 (546 mg, $83 \%) .{ }^{1} \mathrm{H}$ NMR $\left(500 \mathrm{MHz}, \mathrm{CDCl}_{3}\right): \delta=7.36-7.28\left(20 \mathrm{H}, \mathrm{m} ;-\mathrm{C}_{6} \mathrm{H}_{5} \times 4\right)$, $6.57(1 \mathrm{H}, \mathrm{d}, J=7 \mathrm{~Hz} ; \mathrm{NH}), 5.28(2 \mathrm{H}$, brs; $\mathrm{NH} \times 2), 5.17-5.09(8 \mathrm{H}, \mathrm{m}$; $\left.-\mathrm{CH}_{2}-\mathrm{Ph} \times 4\right), 4.54(1 \mathrm{H}, \mathrm{td}, J=6.88,5.5 \mathrm{~Hz}$; DAP $2-\mathrm{H}), 4.40-4.34(2 \mathrm{H}$, m; Glu $\alpha \mathrm{H}$, DAP 6-H), 2.25-2.21 (2 H, m; Glu- $\left.\gamma-\mathrm{CH}_{2}\right), 2.18-2.12(1 \mathrm{H}, \mathrm{m}$; Glu- $\left.\beta \mathrm{CH}_{2}\right)$, 1.92-1.87 (1 H, m; Glu- $\left.\beta_{\mathrm{CH}_{2}}\right), 1.83-1.58(4 \mathrm{H}, \mathrm{m}$; DAP 3$\left.\mathrm{CH}_{2}, 5-\mathrm{CH}_{2}\right), 1.41\left(9 \mathrm{H}, \mathrm{s} ;-\mathrm{C}\left(\mathrm{CH}_{3}\right)_{3}\right), 1.39-1.23 \mathrm{ppm}(2 \mathrm{H}, \mathrm{m}$; DAP 4$\mathrm{CH}_{2}$ ); ESI-TOF-MS (positive): $m / z: 824.37[M+\mathrm{H}]^{+}$.

Protected L-Ala- $\boldsymbol{\gamma}$-D-Glu-meso-DAP 27: Compound 26 (304.6 mg, $0.37 \mathrm{mmol})$ was dissolved in TFA $(3 \mathrm{~mL})$ and stirred for $20 \mathrm{~min}$. After 
this time, the reaction mixture was concentrated in vacuo and $1 \mathrm{~m} \mathrm{HCl}$ ether solution was added to the residue to a give white solid. The supernatant was removed by decantation to give Boc-deprotected 26 . WSCD $\cdot \mathrm{HCl}(75 \mathrm{mg}, 0.48 \mathrm{mmol})$ and triethylamine $(129 \mu \mathrm{L}, 0.93 \mathrm{mmol})$ were added to a solution of Boc-deprotected 26, tert-butoxycarbonyl Lalanine $(70 \mathrm{mg}, 0.37 \mathrm{mmol})$, and HOBt $(65 \mathrm{mg}, 0.48 \mathrm{mmol})$ in dry THF $(4 \mathrm{~mL})$. The reaction was stirred for $3 \mathrm{~h}$ under an Ar atmosphere. After this time the reaction mixture was extracted with AcOEt and the resulting organic layer was washed with $10 \%$ citric acid solution, saturated aq. $\mathrm{NaHCO}_{3}$ and brine, dried over $\mathrm{Na}_{2} \mathrm{SO}_{4}$, and concentrated in vacuo. The residue was purified by silica-gel flash column chromatography (toluene/ AcOEt 1:1) to give $27(319 \mathrm{mg}, 96 \%) .{ }^{1} \mathrm{H} \mathrm{NMR}\left(500 \mathrm{MHz}, \mathrm{CDCl}_{3}\right): \delta=$ 7.34-7.27 $\left(20 \mathrm{H}, \mathrm{m} ;-\mathrm{C}_{6} \mathrm{H}_{5} \times 4\right), 7.16(1 \mathrm{H}, \mathrm{d}, J=5.5 \mathrm{~Hz} ; \mathrm{NH}), 5.45(1 \mathrm{H}, \mathrm{d}$, $J=5 \mathrm{~Hz} ; \mathrm{NH}), 5.16-5.06\left(8 \mathrm{H}, \mathrm{m} ;-\mathrm{CH}_{2}-\mathrm{Ph} \times 4\right), 4.93(1 \mathrm{H}$, brs; $\mathrm{NH})$, $4.53(1 \mathrm{H}, \mathrm{dd}, J=8,13 \mathrm{~Hz}$; DAP $2-\mathrm{H}), 4.48(1 \mathrm{H}$, br s; Glu- $\alpha \mathrm{H}), 4.36(1 \mathrm{H}$, dd, $J=8,13 \mathrm{~Hz}$; DAP 6-H), 4.10-4.08 $(1 \mathrm{H}, \mathrm{m}$; Ala- $\alpha \mathrm{H}), 2.28-2.15(3 \mathrm{H}$, m; Glu- $\gamma \mathrm{H}$, Glu- $\beta \mathrm{H}), 2.04$ (1 H, br s; Glu- $\beta \mathrm{H}), 1.86-1.61$ (4 H, m; DAP 3$\left.\mathrm{CH}_{2}, 5-\mathrm{CH}_{2}\right), 1.42\left(9 \mathrm{H}, \mathrm{s} ; \mathrm{C}\left(\mathrm{CH}_{3}\right)_{3}, 1.40-1.32\left(2 \mathrm{H}, \mathrm{m} ; \mathrm{DAP} 4-\mathrm{CH}_{2}\right)\right.$, $1.26 \mathrm{ppm}\left(3 \mathrm{H}, \mathrm{d}, J=5.5 \mathrm{~Hz}\right.$; Ala- $\left.\mathrm{CCH}_{3}\right)$; ESI-TOF-MS (positive): $\mathrm{m} / \mathrm{z}$ : $895.4[M+\mathrm{H}]^{+}$

Protected H-L-Ala- $\boldsymbol{\gamma}$-D-Glu-meso-DAP 28: Compound 27 (46.5 mg, $0.052 \mathrm{mmol})$ was dissolved in TFA $(400 \mu \mathrm{L})$ and the resulting mixture was stirred for $25 \mathrm{~min}$. After this time, the reaction mixture was concentrated in vacuo and $1 \mathrm{~m} \mathrm{HCl}$ ether solution was added to the residue to give a white solid. The supernatant was removed by decantation to give $28(0.052 \mathrm{mmol})$. The compound was used without further purification.

Protected meso-DAP-D-Ala 29: WSCD. $\mathrm{HCl}(116 \mathrm{mg}, 0.746 \mathrm{mmol})$ and triethylamine $(200 \mu \mathrm{L}, 1.44 \mathrm{mmol})$ were added to a solution of $\mathbf{2 5}$ (295 mg, $0.574 \mathrm{mmol}), \mathrm{HCl} \cdot \mathrm{H}-\mathrm{L}-\mathrm{Ala}-\mathrm{OBn}(136 \mathrm{mg}, 0.631 \mathrm{mmol})$, and HOBt $(101 \mathrm{mg}, 0.746 \mathrm{mmol})$ in dry THF $(6 \mathrm{~mL})$. The reaction mixture was stirred for 1 day under an Ar atmosphere. After this time, the reaction mixture was extracted with AcOEt and the resulting organic layer was washed with $10 \%$ citric acid solution, saturated aqueous $\mathrm{NaHCO}_{3}$, and brine, dried over $\mathrm{Na}_{2} \mathrm{SO}_{4}$, and then concentrated in vacuo. The residue was purified by silica-gel flash column chromatography $\left(\mathrm{CHCl}_{3} /\right.$ acetone $20: 1)$ to give $29(347,7 \mathrm{mg}, 90 \%)$. ${ }^{1} \mathrm{H}$ NMR $\left(500 \mathrm{MHz}, \mathrm{CDCl}_{3}\right): \delta=$ 7.36-7.28 $\left(15 \mathrm{H}, \mathrm{m} ; \mathrm{C}_{6} H_{5} \times 3\right), 6.63(1 \mathrm{H}$, brs; $\mathrm{NH}), 5.39(1 \mathrm{H}, \mathrm{d}, J=$ $7.5 \mathrm{~Hz} ; \mathrm{NH}), 5.19-5.07\left(6 \mathrm{H}, \mathrm{m} ;-\mathrm{CH}_{2}-\mathrm{Ph} \times 3\right), 4.96(1 \mathrm{H}$, br s; $\mathrm{NH}), 4.58$ $(1 \mathrm{H}, \mathrm{m}$; DAP $2-\mathrm{H}), 4.39(1 \mathrm{H}, \mathrm{d}, J=5.5 \mathrm{~Hz}$; DAP $6-\mathrm{H}), 4.05(1 \mathrm{H}$, brs; Ala- $\alpha \mathrm{H}), 1.89-1.53\left(6 \mathrm{H}, \mathrm{m}\right.$; DAP $\left.-\left(\mathrm{CH}_{2}\right)_{3}-\right), 1.43\left(9 \mathrm{H}, \mathrm{s} ;-\mathrm{C}\left(\mathrm{CH}_{3}\right)_{3}\right)$, $1.39 \mathrm{ppm}\left(3 \mathrm{H}, \mathrm{d}, J=7.5 \mathrm{~Hz}\right.$; Ala- $\left.\beta \mathrm{CH}_{3}\right)$; elemental analysis calcd (\%) for $\mathrm{C}_{37} \mathrm{H}_{45} \mathrm{~N}_{3} \mathrm{O}_{9} \cdot 0.6 \mathrm{H}_{2} \mathrm{O}$ : C 64.73, H 6.78, N 6.12; found: $\mathrm{C} 64.33, \mathrm{H} 6.42, \mathrm{~N}$ 6.39; ESI-TOF-MS (positive): $m / z: 676.3[M+\mathrm{H}]^{+}$

Protected H-L-Ala- $\boldsymbol{\gamma}$-D-Glu-meso-DAP-D-Ala 30: Compound 29 (328 mg, $0.486 \mathrm{mmol})$ was dissolved in TFA $(4 \mathrm{~mL})$ and the mixture was stirred for $1 \mathrm{~h}$. After this time, the reaction mixture was concentrated and then co-evapolated in toluene $(\times 2)$. $1 \mathrm{M} \mathrm{HCl}$ ether solution was added to the residue and the mixture was evaporated in vacuo. The residue was freeze-dried by using 1,4-dioxane to give an oil. WSCD. $\mathrm{HCl}(98 \mathrm{mg}$, $0.632 \mathrm{mmol})$ and triethylamine $(169 \mu \mathrm{L}, 1.22 \mathrm{mmol})$ were added to a solution of the oil, Boc-D-Glu-OBn (180 mg, $0.535 \mathrm{mmol})$, and HOBt $(85 \mathrm{mg}$, $0.632 \mathrm{mmol})$ in dry THF $(5 \mathrm{~mL})$. The reaction mixture was stirred for $24 \mathrm{~h}$ under an Ar atmosphere, after which time, it was extracted with AcOEt. The organic layer was washed with $10 \%$ citric acid solution, saturated aqueous $\mathrm{NaHCO}_{3}$, and brine, dried over $\mathrm{Na}_{2} \mathrm{SO}_{4}$, and then concentrated in vacuo. The residue was purified by silica-gel flash column chromatography $\left(\mathrm{CHCl}_{3} /\right.$ acetone $\left.10: 1\right)$ to give fully protected $\gamma$-D-Glumeso-DAP-D-Ala (416.4 mg, 96\%). ${ }^{1} \mathrm{H}$ NMR $\left(500 \mathrm{MHz}, \mathrm{CDCl}_{3}\right): \delta=$ 7.38-7.27 $(20 \mathrm{H}, \mathrm{m} ;-\mathrm{Ph} \times 4), 7.01(1 \mathrm{H}$, brs; NH), $6.22(1 \mathrm{H}$, brs; $\mathrm{NH})$, $5.44\left(1 \mathrm{H}\right.$, brs; NH), $5.31\left(1 \mathrm{H}\right.$, brs; NH), 5.19-5.06 $\left(8 \mathrm{H}, \mathrm{m} ;-\mathrm{CH}_{2}-\mathrm{Ph}\right.$ $\times 4), 4.56(1 \mathrm{H}, \mathrm{m}$; DAP 2-H), 4.38-4.30 (3H, m; Ala- $\alpha \mathrm{H}$, Glu- $\alpha \mathrm{H}, \mathrm{DAP}$ 6-H), 2.28-2.15 (3 H, m; Glu- $\gamma \mathrm{H}$, Glu- $\beta \mathrm{H}), 1.88-1.64(5 \mathrm{H}, \mathrm{m}$; Glu- $\beta \mathrm{H}$, DAP 3- $\left.\mathrm{CH}_{2}, 5-\mathrm{CH}_{2}\right), 1.40\left(9 \mathrm{H}, \mathrm{s} ;-\mathrm{C}\left(\mathrm{CH}_{3}\right)_{3}\right), 1.35(3 \mathrm{H}, \mathrm{d}, J=7 \mathrm{~Hz}$; Ala$\left.\mathrm{\beta CH}_{3}\right), 1.27-1.23 \mathrm{ppm}\left(2 \mathrm{H}, \mathrm{m}\right.$; DAP-4- $\left.\mathrm{CH}_{2}\right)$; elemental analysis calcd (\%) for $\mathrm{C}_{49} \mathrm{H}_{58} \mathrm{~N}_{4} \mathrm{O}_{12} \cdot \mathrm{H}_{2} \mathrm{O}$ : C 64.46, $\mathrm{H}$ 6.62, N 6.14; found: $\mathrm{C} 64.66, \mathrm{H}$ 6.54, N 6.31; ESI-TOF-MS (positive): $m / z: 895.4[M+\mathrm{H}]^{+}$.

The fully protected $\gamma$-D-Glu-meso-DAP-D-Ala $(322 \mathrm{mg}, 0.36 \mathrm{mmol})$ was dissolved in TFA $(2 \mathrm{~mL})$ and stirred for $40 \mathrm{~min}$. The reaction mixture was concentrated and co-evaporated in toluene $(\times 2) .1 \mathrm{~m} \mathrm{HCl}$ ether solution was added to the residue to give white solid, and the supernatant was removed by decantation. WSCD. $\mathrm{HCl}(73 \mathrm{mg}, 0.468 \mathrm{mmol})$ and triethylamine $(125 \mu \mathrm{L}, 0.900 \mathrm{mmol})$ were added to a solution of the residue, Boc-L-Ala-OBn (75 mg, $0.396 \mathrm{mmol})$, and HOBt $(63 \mathrm{mg}, 0.468 \mathrm{mmol})$ in dry DMF (4 mL). The reaction was stirred for 1 day under an $\mathrm{Ar}$ atmosphere. The reaction was extracted with AcOEt and the resulting organic layer was washed with $10 \%$ citric acid solution, saturated aqueous $\mathrm{NaHCO}_{3}$, and brine, dried over $\mathrm{Na}_{2} \mathrm{SO}_{4}$, and then concentrated in vacuo. The residue was purified by silica-gel flash column chromatography $\left(\mathrm{CHCl}_{3} /\right.$ acetone $\left.5: 1\right)$ to give fully protected L-Ala- $\gamma$-D-Glu-meso-DAP-DAla $(277 \mathrm{mg}, 80 \%) .{ }^{1} \mathrm{H}$ NMR $\left(500 \mathrm{MHz}, \mathrm{CDCl}_{3}\right): \delta=7.36-7.28(20 \mathrm{H}, \mathrm{m}$; $\left.\mathrm{C}_{6} H_{5} \times 4\right), 7.05(1 \mathrm{H}$, brs; NH), $7.05(1 \mathrm{H}$, brs; $\mathrm{NH}), 5.43(1 \mathrm{H}, \mathrm{d}, J=6 \mathrm{~Hz}$ $\mathrm{NH}), 5.18-5.05\left(8 \mathrm{H}, \mathrm{m} ;-\mathrm{CH}_{2}-\mathrm{Ph} \times 4\right), 4.91(1 \mathrm{H}, \mathrm{brs} ; \mathrm{NH}), 4.57(1 \mathrm{H}, \mathrm{m}$, $J=7.5 \mathrm{~Hz}$; DAP 2-H), 4.51-4.36 (3 H, m; Glu- $\alpha \mathrm{H}$, D-Ala- $\alpha \mathrm{H}$, DAP 6-H), 4.12-4.05 $(1 \mathrm{H}, \mathrm{m}$; L-Ala- $\alpha \mathrm{H}), 2.40(1 \mathrm{H}$, brs; NH), 2.25-2.15 $(3 \mathrm{H}, \mathrm{m}$; Glu- $\gamma \mathrm{CH}_{2}$, Glu- $\left.\beta \mathrm{CH}_{2}\right), 1.94-1.63\left(5 \mathrm{H}, \mathrm{m}\right.$; Glu- $\beta_{\mathrm{CH}}, \mathrm{DAP} 3-\mathrm{CH}_{2}, 5-$ $\left.\mathrm{CH}_{2}\right), 1.45-1.21\left(2 \mathrm{H}, \mathrm{m}\right.$; DAP $\left.4-\mathrm{CH}_{2}\right), 1.42\left(9 \mathrm{H}, \mathrm{s} ; \mathrm{C}\left(\mathrm{CH}_{3}\right)_{3}\right), 1.37(3 \mathrm{H}$, d, $\left.J=7 \mathrm{~Hz} ; \mathrm{D}-\mathrm{Ala}-\beta \mathrm{CH}_{3}\right), 1.27(3 \mathrm{H}, \mathrm{d}, J=7 \mathrm{~Hz}$; L-Ala- $\beta \mathrm{H})$; elemental analysis calcd (\%) for $\mathrm{C}_{52} \mathrm{H}_{63} \mathrm{~N}_{5} \mathrm{O}_{13} \cdot \mathrm{H}_{2} \mathrm{O}: \mathrm{C}$ 63.46, $\mathrm{H}$ 6.66, N 7.12; found: C 63.55, H 6.52, N 7.33; ESI-TOF-MS (positive): $m / z: 966.4[M+\mathrm{H}]^{+}$

The fully-protected L-Ala- $\gamma$-D-Glu-meso-DAP-D-Ala (28 mg, $0.0285 \mathrm{mmol})$ was dissolved in TFA $(200 \mu \mathrm{L})$ and stirred for $20 \mathrm{~min}$. The reaction mixture was concentrated in vacuo and $1 \mathrm{~m} \mathrm{HCl}$ ether solution was added to the resulting residue to give a white solid. The supernatant was removed by decantation to give $\mathbf{3 0}(0.0285 \mathrm{mmol})$. The compound was used without further purification.

1,6-Anhydro-2-azide-4- $O$-benzyl-2-deoxy-3- $O$-[(1R)-1-(ethyoxycarbonyl)-

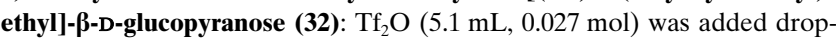
wise to a solution of $(S)$-LacOEt $(3.2 \mathrm{~g}, 0.027 \mathrm{~mol})$ and 2,6-lutidine $(3 \mathrm{~mL}, 0.027 \mathrm{~mol})$ in $\mathrm{CH}_{2} \mathrm{Cl}_{2}(50 \mathrm{~mL})$ at $-70^{\circ} \mathrm{C}$ under an $\mathrm{Ar}$ atmosphere. The reaction mixture was stirred for $2 \mathrm{~h}$ at RT. Hexane $(30 \mathrm{~mL})$ was added to the solution, and the mixture was purified by silica-gel column chromatography (silica-gel $150 \mathrm{~g}$, hexane $/ \mathrm{CH}_{2} \mathrm{Cl}_{2}$ 1:1) to give lactic triflate. $\mathrm{NaH}(1.3 \mathrm{~g}, 0.027 \mathrm{~mol})$ was added to the $\mathrm{CH}_{2} \mathrm{Cl}_{2}$ solution of $\mathbf{3 1}(5 \mathrm{~g}$, $0.018 \mathrm{~mol}$ ) under an Ar atmosphere, and the mixture was stirred for $15 \mathrm{~min}$. After this time, lactic triflate was added to the reaction mixture and it was stirred for a further $1 \mathrm{~h}$. The reaction was quenched with ice and the organic layer was washed with saturated aqueous $\mathrm{NaHCO}_{3}$ and brine, dried over $\mathrm{Na}_{2} \mathrm{SO}_{4}$, and concentrated in vacuo. The residue was purified by silica-gel flash column chromatography $\left(\mathrm{CHCl}_{3}\right.$ /acetone 100:1) to give $32\left(5.2 \mathrm{~g}, 78 \%\right.$ ); ESI-TOF-MS (positive): $\mathrm{m} / \mathrm{z}: 777.32[2 \mathrm{M}+\mathrm{Na}]^{+}$. 2-Acetylamino-1,6-anhydro-2-deoxy-4- $O$-benzyl-3- $O$-[(1R)-1-(ethyoxycar-

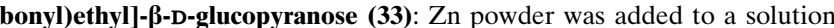
of $32(1 \mathrm{~g}, 2.65 \mathrm{mmol})$ in AcOH/THF $1: 1(4 \mathrm{~mL})$ at $0{ }^{\circ} \mathrm{C}$, and the resulting mixture was stirred for $10 \mathrm{~min}$. After this time, the $\mathrm{Zn}$ powder was removed by filtration and the filtrate was concentrated in vacuo. The residue was dissolved in $\mathrm{Ac}_{2} \mathrm{O} / \mathrm{pyr}$ 1:1 $(20 \mathrm{~mL})$, and the reaction mixture was stirred for a further $45 \mathrm{~min}$. The reaction mixture was evaporated in vacuo and the residue was extracted with AcOEt. The organic layer was washed with $1 \mathrm{M} \mathrm{HCl}$ aq. and brine, dried over $\mathrm{Na}_{2} \mathrm{SO}_{4}$, and concentrated in vacuo. The residue was purified by silica-gel flash column chromatography (toluene/AcOEt 2:1) to give 33 (786 mg, 79\%). ${ }^{1} \mathrm{H}$ NMR $\left(500 \mathrm{MHz}, \mathrm{CDCl}_{3}\right): \delta=7.39-7.33(5 \mathrm{H}, \mathrm{m} ; \mathrm{ArH}), 6.30(1 \mathrm{H}, \mathrm{d}, J=8.5 \mathrm{~Hz}$ $\mathrm{NH}), 5.35$ (1 H, s; H-1), $4.68\left(1 \mathrm{H}, \mathrm{d}, J=12 \mathrm{~Hz}\right.$; $\left.\mathrm{PhCH}_{2}-\mathrm{O}-\right), 4.59(1 \mathrm{H}, \mathrm{d}$, $\left.J=12 \mathrm{~Hz} ; \mathrm{PhCH}_{2}-\mathrm{O}-\right), 4.56(1 \mathrm{H}, \mathrm{s} ; \mathrm{H}-5), 4.24-4.18(3 \mathrm{H}, \mathrm{m} ; \mathrm{Lac}-\alpha \mathrm{H}$ $\left.-\mathrm{COOCH}_{2} \mathrm{CH}_{3}\right), 3.72\left(1 \mathrm{H}, \mathrm{dd}, J=6.7 \mathrm{~Hz} ; \mathrm{H}-6^{\prime}\right), 3.48-3.46(1 \mathrm{H}, \mathrm{m} ; \mathrm{H}-3)$, $3.42(1 \mathrm{H}, \mathrm{s} ; \mathrm{H}-4), 1.94$ (3 H, s; NHAc), $1.38\left(3 \mathrm{H}, \mathrm{d}, J=7 \mathrm{~Hz} ; \mathrm{Lac}^{-} \mathrm{\beta CH}_{3}\right)$, $1.29 \mathrm{ppm}\left(3 \mathrm{H}, \mathrm{t}, J=7 \mathrm{~Hz} ;-\mathrm{COOCH}_{2} \mathrm{CH}_{3}\right)$; ESI-TOF-MS (positive): $m / z: 394.1[M+\mathrm{H}]^{+}$.

2-Acetylamino-1,6-anhydro-2-deoxy-4-O-benzyl-3-O-[(1R)-1-(carboxyl)ethyl]- $\boldsymbol{\beta}$-D-glucopyranose (34): Compound $\mathbf{3 3}(75 \mathrm{mg}, 0.19 \mathrm{mmol})$ was dissolved in THF/1,4-dioxane $/ \mathrm{H}_{2} \mathrm{O} \quad 2: 1: 0.5 \quad(2 \mathrm{~mL}) . \quad \mathrm{LiOH} \cdot \mathrm{H}_{2} \mathrm{O} \quad(9 \mathrm{mg}$, $0.21 \mathrm{mmol}$ ) was added to the reaction mixture and it was stirred for $1.5 \mathrm{~h}$. After this time, the reaction mixture was quenched with Dowex $\mathrm{H}^{+}$, which was subsequently removed by filtration. The mixture was then concentrated in vacuo and the resulting residue was purified by silica-gel flash column chromatography $\left(\mathrm{CHCl}_{3} / \mathrm{MeOH} 20: 1\right)$ to give 34 (30.1 mg, 
$44 \%) .{ }^{1} \mathrm{H}$ NMR $\left(500 \mathrm{MHz}, \mathrm{CDCl}_{3}\right): \delta=7.43-7.33(5 \mathrm{H}, \mathrm{m} ; \mathrm{ArH}), 6.14$ $(1 \mathrm{H}, \mathrm{d}, J=5 \mathrm{~Hz} ; \mathrm{NH}), 5.45(1 \mathrm{H}, \mathrm{s} ; \mathrm{H}-1), 4.68\left(1 \mathrm{H}, \mathrm{d}, J=12 \mathrm{~Hz} ; \mathrm{PhCH}_{2}-\right.$ $\left.\mathrm{O}^{-}\right), 4.66-4.64(1 \mathrm{H}, \mathrm{m} ; \mathrm{H}-5), 4.59\left(1 \mathrm{H}, \mathrm{d}, J=12 \mathrm{~Hz} ; \mathrm{PhCH}_{2}-\mathrm{O}^{-}\right), 4.26-$ $4.21(1 \mathrm{H}, \mathrm{m} ; \mathrm{Lac}-\alpha \mathrm{H}), 4.18(1 \mathrm{H}, \mathrm{d}, J=7.5 \mathrm{~Hz} ; \mathrm{H}-6), 4.19-4.11(1 \mathrm{H}, \mathrm{m}$; H-2), 3.80-3.76 (1 H, m; H-6'), $3.55(1 \mathrm{H}, \mathrm{s} ; \mathrm{H}-3), 3.44(1 \mathrm{H}, \mathrm{s} ; \mathrm{H}-4), 1.95$ $\left(3 \mathrm{H}, \mathrm{s}\right.$; NHAc), $1.39 \mathrm{ppm}\left(3 \mathrm{H}, \mathrm{s}\right.$; Lac- $\left.\beta_{\mathrm{CH}}\right)$; ESI-TOF-MS (positive): $m / z: 364.1[M-\mathrm{H}]$

\section{2-Trichloroethoxycarbonylamino-1,6-anhydro-2-deoxy-4-O-[(1R)-1-} (ethyoxycarbonyl)ethyl]- $\beta$-D-glucopyranose (36): $\mathrm{Pd}(\mathrm{OH})_{2}(60 \mathrm{mg})$ was added to a solution of $\mathbf{3 2}(50.7 \mathrm{mg}, 0.13 \mathrm{mmol})$ in THF $(1 \mathrm{~mL})$ and the reaction mixture was stirred for 2 days under a $\mathrm{H}_{2}$ atmosphere $\left(15 \mathrm{~kg} \mathrm{~cm}^{-2}\right)$. After this time, the $\mathrm{Pd}(\mathrm{OH})_{2}$ was removed by membrane filtration, and the filtrate was concentrated in vacuo. The resulting residue, TrocCl $(22 \mu \mathrm{L}, 0.16 \mathrm{mmol})$, and triethylamine $(28 \mu \mathrm{L}, 0.20 \mathrm{mmol})$ were then dissolved in $\mathrm{CH}_{2} \mathrm{Cl}_{2}(1 \mathrm{~mL})$ and stirred for $15 \mathrm{~min}$. The reaction mixture was extracted with $\mathrm{CHCl}_{3}$. The organic layer was washed with saturated aqueous $\mathrm{NaHCO}_{3}$, dried over $\mathrm{Na}_{2} \mathrm{SO}_{4}$, and concentrated in vacuo. The residue was purified by silica-gel flash column chromatography (toluene/AcOEt 5:1) to give $36(44.4 \mathrm{mg}, 77 \%)$. ${ }^{1} \mathrm{H}$ NMR $\left(500 \mathrm{MHz}, \mathrm{CDCl}_{3}\right)$ : $\delta=5.67(1 \mathrm{H}, \mathrm{d}, J=9 \mathrm{~Hz} ; \mathrm{H}-1), 5.44(1 \mathrm{H}, \mathrm{s} ; \mathrm{N} H), 4.73(2 \mathrm{H}, \mathrm{dd}, J=12$, $\left.21 \mathrm{~Hz} ;-\mathrm{CH}_{2}-\mathrm{CCl}_{3}\right), 4.52(1 \mathrm{H}$, brs; H-5), 4.24-4.18 $(4 \mathrm{H}, \mathrm{m} ; \mathrm{Lac}-\alpha \mathrm{H}$, $\left.-\mathrm{COOCH}_{2} \mathrm{CH}_{3}, \mathrm{H}-6\right), 3.91(1 \mathrm{H}, \mathrm{d}, J=9.2 \mathrm{~Hz} ; \mathrm{H}-2), 3.80-3.76(2 \mathrm{H}, \mathrm{m}$; H-6', H-3), $3.50 \mathrm{ppm}$ (1 H, brs; H-4); ESI-TOF-MS (positive): $\mathrm{m} / z$ : $526.13[M+\mathrm{H}]^{+}$

1,6-Anhydro-4- $O$-[3'-O-benzyl-4', $\mathbf{6}^{\prime}-O$-benzylidene-2' - deoxy-2' $-(2,2,2$-trichloroethoxycarbonylamino)- $\beta$-D-glucopyranosyl]-3- $O$-[ $[R$ )-1-(ethoxycarbonyl)ethyl]-2-deoxy-2-(2,2,2-trichloroethoxycarbonylamino)-D-glucopyranoside (38): TMSOTf $(5 \mathrm{~mL}, 0.030 \mathrm{mmol})$ was added to the solution of glucosamine imidate 37 (200 mg, $0.296 \mathrm{mmol}), \mathbf{3 6}(193.6 \mathrm{mg}, 0.443 \mathrm{mmol})$, and MS $(4 \AA)$ in dry $\mathrm{CH}_{2} \mathrm{Cl}_{2}(3 \mathrm{~mL})$ at $-17^{\circ} \mathrm{C}$, and the mixture was stirred for 30 min under an $\mathrm{Ar}$ atmosphere. After this time, the reaction was quenched with saturated aqueous $\mathrm{NaHCO}_{3}$ and the organic layer was washed with brine, dried over $\mathrm{Na}_{2} \mathrm{SO}_{4}$, and then concentrated in vacuo. The residue was purified by silica-gel flash column chromatography (toluene/AcOEt 7:1) to give $\mathbf{3 8}(182 \mathrm{mg}, 65 \%) .{ }^{1} \mathrm{H}$ NMR $(500 \mathrm{MHz}$, $\left.\mathrm{CDCl}_{3}\right): \delta=7.52-7.18(10 \mathrm{H}, \mathrm{m} ; \mathrm{Ar} H \times 2), 5.60\left(1 \mathrm{H}, \mathrm{s} ; \mathrm{Ph}-\mathrm{C} H=\mathrm{O}_{2}\right), 5.33$ $\left(1 \mathrm{H}, \mathrm{s} ; \mathrm{H}_{\mathrm{anh}}-1\right), 5.03(1 \mathrm{H}, \mathrm{d}, J=7.7 \mathrm{~Hz} ; \mathrm{N} H), 4.91\left(1 \mathrm{H}, \mathrm{d}, J=12 \mathrm{~Hz} ;-\mathrm{O}^{-}\right.$ $\left.\mathrm{CH}_{2}-\mathrm{Ph}\right), 4.82(1 \mathrm{H}, \mathrm{d}, J=8 \mathrm{~Hz} ; \mathrm{H}-1), 4.76\left(2 \mathrm{H}, \mathrm{dd}, J=12,20 \mathrm{~Hz} ;-\mathrm{CH}_{2}-\right.$ $\left.\mathrm{CCl}_{3}\right), 4.7\left(1 \mathrm{H}, \mathrm{d}, J=12 \mathrm{~Hz} ;-\mathrm{O}-\mathrm{CH}_{2}-\mathrm{Ph}\right), 4.60(1 \mathrm{H}, \mathrm{d}, J=12 \mathrm{~Hz} ; \mathrm{N} H)$, $4.49\left(1 \mathrm{H}, \mathrm{d}, J=5.7 \mathrm{~Hz} ; \mathrm{H}_{\mathrm{anh}}-5\right), 4.33(1 \mathrm{H}, \mathrm{dd}, J=5,10 \mathrm{~Hz} ; \mathrm{H}-6), 4.22$ $(1 \mathrm{H}, \mathrm{q}, J=3.6 \mathrm{~Hz} ; \mathrm{Lac}-\alpha \mathrm{H}), 4.20-4.14\left(3 \mathrm{H}, \mathrm{m} ;-\mathrm{CH}_{2} \mathrm{CH}_{3}, \mathrm{H}_{\mathrm{anh}}-6^{\prime}\right), 3.95$ $\left(1 \mathrm{H}, \mathrm{d}, J=9.8 \mathrm{~Hz} ; \mathrm{H}_{\mathrm{anh}}-2\right), 3.86-3.76(3 \mathrm{H}, \mathrm{m} ; \mathrm{H}-3, \mathrm{H}-6, \mathrm{H}-4), 3.74-3.72$ $\left(2 \mathrm{H}, \mathrm{m} ; \mathrm{H}_{\mathrm{anh}}-6^{\prime}, \mathrm{H}_{\mathrm{anh}}-4\right), 3.58\left(1 \mathrm{H}, \mathrm{brs} ; \mathrm{H}_{\mathrm{anh}}-3\right), 3.52-3.42 \mathrm{ppm}(2 \mathrm{H}, \mathrm{m}$; $\mathrm{H}-2, \mathrm{H}-5)$; elemental analysis calcd (\%) for $\mathrm{C}_{37} \mathrm{H}_{42} \mathrm{Cl}_{6} \mathrm{~N}_{2} \mathrm{O}_{14}: \mathrm{C} 46.71, \mathrm{H}$ 4.45, N 2.94; found: C 47.02, H 4.42, N 2.96; ESI-TOF-MS (positive): $\mathrm{m} / z$ : $949.17[M+\mathrm{H}]^{+}$

1,6-Anhydro-4-O-(3'-O-benzyl-4',6'-O-benzylidene-2'-deoxy-2' -acetylami-

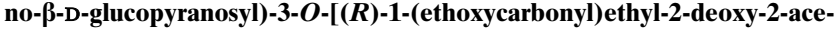
tylamino]-D-glucopyranoside (39): Compound $\mathbf{3 8}(40.6 \mathrm{mg}, 0.0427 \mathrm{mmol})$ was dissolved in $\mathrm{Ac}_{2} \mathrm{O} / \mathrm{AcOH} / \mathrm{THF}$ 1:1:1 $(600 \mu \mathrm{L})$. $\mathrm{Zn} / \mathrm{Cu}$ was added and the mixture was stirred for $1 \mathrm{~h}$. After this time, the $\mathrm{Zn} / \mathrm{Cu}$ was removed by filtration and the filtrate was concentrated in vacuo. The residue was extracted with $\mathrm{AcOEt}$ and the organic layer was washed with saturated aqueous $\mathrm{NaHCO}_{3}$ and brine, dried over $\mathrm{Na}_{2} \mathrm{SO}_{4}$, and then concentrated in vacuo. The residue was purified by silica-gel flash column chromatography $\left(\mathrm{CHCl}_{3} /\right.$ acetone $\left.3: 1\right)$ to give $39(23.5 \mathrm{mg}, 81 \%) .{ }^{1} \mathrm{H} \mathrm{NMR}$ $\left(500 \mathrm{MHz}, \mathrm{CDCl}_{3}\right): \delta=7.51-7.31(10 \mathrm{H}, \mathrm{m} ; \operatorname{Ar} H \times 2), 6.77(1 \mathrm{H}, \mathrm{d}, J=$ $9.5 \mathrm{~Hz} ; \mathrm{NH}), 5.61\left(1 \mathrm{H}, \mathrm{s} ; \mathrm{Ph}-\mathrm{CH}=\mathrm{O}_{2}\right), 5.25\left(1 \mathrm{H}, \mathrm{s} ; \mathrm{H}_{\mathrm{anh}}-1\right), 5.07(1 \mathrm{H}, \mathrm{d}$, $J=8 \mathrm{~Hz} ; \mathrm{NH}), 4.91\left(1 \mathrm{H}, \mathrm{d}, J=12 \mathrm{~Hz} ;-{ }^{-}-\mathrm{CH}_{2}-\mathrm{Ph}\right), 4.67(1 \mathrm{H}, \mathrm{d}, J=$ $\left.12 \mathrm{~Hz} ;-\mathrm{O}-\mathrm{CH}_{2}-\mathrm{Ph}\right), 4.54(1 \mathrm{H}, \mathrm{d}, J=8.5 \mathrm{~Hz} ; \mathrm{H}-1), 4.41(1 \mathrm{H}, \mathrm{d}, J=5 \mathrm{~Hz}$; $\left.\mathrm{H}_{\text {anh }}-5\right), 4.34(1 \mathrm{H}, \mathrm{dd}, J=5,10.5 \mathrm{~Hz} ; \mathrm{H}-6), 4.24-4.16\left(5 \mathrm{H}, \mathrm{m} ; \mathrm{H}_{\text {anh }}-2\right.$, $\mathrm{H}_{\text {anh }}-6$, Lac- $\left.\alpha \mathrm{H},-\mathrm{COOCH}_{2} \mathrm{CH}_{3}\right), 3.92(1 \mathrm{H}, \mathrm{dd}, J=8.5,13.5 \mathrm{~Hz} ; \mathrm{H}-2)$, $3.82\left(1 \mathrm{H}, \mathrm{t}, J=10.5 \mathrm{~Hz} ; \mathrm{H}-6^{\prime}\right), 3.78(1 \mathrm{H}, \mathrm{t}, J=9.3 \mathrm{~Hz} ; \mathrm{H}-4), 3.72(1 \mathrm{H}, \mathrm{s}$; $\left.\mathrm{H}_{\text {anh }}-6^{\prime}\right), 3.69\left(1 \mathrm{H}, \mathrm{t} ; \mathrm{H}_{\text {anh }}-4\right), 3.63(1 \mathrm{H}, \mathrm{t}, J=9.7 \mathrm{~Hz} ; \mathrm{H}-3), 3.46(1 \mathrm{H}, \mathrm{s}$; $\left.\mathrm{H}_{\text {anh }}-3\right), 3.42-3.37(1 \mathrm{H}, \mathrm{m} ; \mathrm{H}-5), 2.09(3 \mathrm{H}, \mathrm{s} ; \mathrm{NHAc}), 1.90(3 \mathrm{H}, \mathrm{s}$; NHAc), $1.39\left(3 \mathrm{H}, \mathrm{d}, J=7 \mathrm{~Hz} ; \mathrm{Lac}-\left(\mathrm{CH}_{3}\right), 1.27(3 \mathrm{H}, \mathrm{t}, J=3.8 \mathrm{~Hz}\right.$; $-\mathrm{COOCH}_{2} \mathrm{CH}_{3}$ ); elemental analysis calcd for $\mathrm{C}_{35} \mathrm{H}_{44} \mathrm{~N}_{2} \mathrm{O}_{12} \cdot 0.4 \mathrm{H}_{2} \mathrm{O}$ : C
64.33, H 6.81, N 3.33; found: C 64.38, H 6.82, N 3.22; ESI-TOF-MS (positive): $m / z: 685.35[M+\mathrm{H}]^{+}$

1,6-Anhydro-4- $O$ - (3'-O-benzyl-4',6'-O-benzylidene-2'-deoxy-2'-acetylamino- $\beta$-D-glucopyranosyl)-3- $O$ - $[(R)$-1-(carbonyloxy)ethyl-2-deoxy-2-acetylaminol-D-glucopyranoside (40): Compound $39(55.2 \mathrm{mg}, 0.0806 \mathrm{mmol})$ was dissolved in THF/1,4-dioxane $/ \mathrm{H}_{2} \mathrm{O}$ 2:1:0.5. $\mathrm{LiOH} \cdot \mathrm{H}_{2} \mathrm{O} \quad(3.7 \mathrm{mg}$, $0.0887 \mathrm{mmol}$ ) was then added to the solution and the reaction mixture was stirred for $2 \mathrm{~h}$. After this time, the reaction mixture was quenched with Dowex $\mathrm{H}^{+}$, which was subsequently removed by filtration. The mixture was then concentrated in vacuo and the resulting residue was applied to an HP-20 column $(2 \times 8 \mathrm{~cm})$. Organic and inorganic salts were removed by elution with $\mathrm{H}_{2} \mathrm{O}$, followed elution with $\mathrm{MeOH}$ to give 40 (45.5 mg, $88 \%$ ).

Protected disaccharide(anh) tetrapeptide 41: WSCD. $\mathrm{HCl} \quad(7 \mathrm{mg}$, $0.043 \mathrm{mmol})$ and triethylamine $(14 \mu \mathrm{L}, 0.098 \mathrm{mmol})$ were added to a solution of 40 (21.5 mg, $0.033 \mathrm{mmol})$, tetrapeptide 30, and HOBt $(6 \mathrm{mg}$, $0.043 \mathrm{mmol})$ in dry DMF $(700 \mu \mathrm{L})$. The reaction mixture was stirred for 1 day under an $\mathrm{Ar}$ atmosphere. After this time, the reaction mixture was extracted with AcOEt and the organic layer was washed with $10 \%$ citric acid solution, saturated aq. $\mathrm{NaHCO}_{3}$, and brine, dried over $\mathrm{Na}_{2} \mathrm{SO}_{4}$, and then concentrated in vacuo. The residue was purified by silica-gel flash column chromatography $\left(\mathrm{CHCl}_{3} /\right.$ acetone $\left.3: 2\right)$ to give $\mathbf{4 1}(45.3 \mathrm{mg}, 92 \%)$ ${ }^{1} \mathrm{H}$ NMR $\left(500 \mathrm{MHz}, \mathrm{CDCl}_{3}\right): \delta=7.84(1 \mathrm{H}, \mathrm{d}, J=6 \mathrm{~Hz} ; \mathrm{NH}), 7.43-7.27$ $(30 \mathrm{H}, \mathrm{m} ; \operatorname{Ar} H \times 6), 7.08(1 \mathrm{H}, \mathrm{d}, J=8 \mathrm{~Hz} ; \mathrm{NH}), 6.93(1 \mathrm{H}, \mathrm{d}, J=10.5 \mathrm{~Hz}$ $\mathrm{NH}), 5.68(1 \mathrm{H}, \mathrm{d}, J=8 \mathrm{~Hz} ; \mathrm{NH}), 5.59\left(1 \mathrm{H}, \mathrm{s} ; \mathrm{Ph}-\mathrm{CH}=\mathrm{O}_{2}\right), 5.30(1 \mathrm{H}, \mathrm{s}$; $\left.\mathrm{H}_{\mathrm{anh}}-1\right), 5.17-5.05\left(10 \mathrm{H}, \mathrm{m} ;-\mathrm{CH}_{2}-\mathrm{Ph}\right), 4.91(1 \mathrm{H}, \quad \mathrm{d}, \quad J=12.5 \mathrm{~Hz}$ $\left.-\mathrm{OCH}_{2} \mathrm{Ph}\right), 4.68\left(1 \mathrm{H}, \mathrm{d}, J=12 \mathrm{~Hz} ;-\mathrm{OCH}_{2} \mathrm{Ph}\right), 4.53(1 \mathrm{H}, \mathrm{m}, J=7 \mathrm{~Hz}$ D-Ala- $\alpha \mathrm{H}), 4.45-4.42\left(2 \mathrm{H}, \mathrm{m} ; \mathrm{H}_{\mathrm{anh}}-5, \mathrm{H}-1\right), 4.38-4.28(5 \mathrm{H}, \mathrm{m} ; \mathrm{H}-6$, Lac$\alpha \mathrm{H}$, Glu- $\alpha \mathrm{H}$, DAP 2-H, DAP 6-H), $4.22\left(1 \mathrm{H}, \mathrm{d}, J=7 \mathrm{~Hz} ; \mathrm{H}_{\mathrm{anh}}-6\right), 4.12-$ $4.06\left(2 \mathrm{H}, \mathrm{m} ; \mathrm{H}_{\mathrm{anh}}-2\right.$, L-Ala- $\left.\alpha \mathrm{H}\right), 4.03-3.98(1 \mathrm{H}, \mathrm{m} ; \mathrm{H}-2), 3.82-3.70(4 \mathrm{H}$, m; H-6; H-4, $\left.\mathrm{H}_{\text {anh }}-6^{\prime}, \mathrm{H}_{\mathrm{anh}}-4\right), 3.55(1 \mathrm{H}, \mathrm{t}, J=9 \mathrm{~Hz} ; \mathrm{H}-3), 3.46(1 \mathrm{H}, \mathrm{s}$; $\left.\mathrm{H}_{\text {anh }}-3\right), 3.39-3.35(1 \mathrm{H}, \mathrm{m} ; \mathrm{H}-5), 2.41-2.34\left(1 \mathrm{H}, \mathrm{m} ; \mathrm{Glu}-\gamma \mathrm{CH}_{2}\right), 2.24-2.19$ $\left(1 \mathrm{H}, \mathrm{m}\right.$; Glu- $\left.\gamma \mathrm{CH}_{2}\right), 2.17-2.11\left(1 \mathrm{H}, \mathrm{m}\right.$; Glu- $\left.\beta \mathrm{CH}_{2}\right), 2.10(3 \mathrm{H}, \mathrm{s}$; NHAc), 1.97-1.94 (1 H, m; Glu- $\left.\beta \mathrm{CH}_{2}\right), 1.91(3 \mathrm{H}, \mathrm{s} ; \mathrm{NHAc}), 1.88-1.61(4 \mathrm{H}, \mathrm{m}$; DAP 3- $\mathrm{CH}_{2}$, DAP 5- $\left.\mathrm{CH}_{2}\right), 1.49-1.37\left(2 \mathrm{H}, \mathrm{m}\right.$; DAP $\left.4-\mathrm{CH}_{2}\right), 1.35(6 \mathrm{H}, \mathrm{d}$, $J=7 \mathrm{~Hz}$; Lac- $\beta \mathrm{CH}_{3}$, D-Ala- $\left.\beta \mathrm{CH}_{3}\right), 1.30 \mathrm{ppm}(3 \mathrm{H}, \mathrm{d}, J=6.5 \mathrm{~Hz}$; L-Ala$\beta \mathrm{CH}_{3}$ ); ESI-TOF-MS (positive): $\mathrm{m} / \mathrm{z}: 1504.61[\mathrm{M}+\mathrm{H}]^{+}$; HRMS-ESI QTOF-MS (positive): $m / z$ : calcd for $\mathrm{C}_{80} \mathrm{H}_{93} \mathrm{~N}_{7} \mathrm{O}_{22}: 1526.6272[M+\mathrm{Na}]^{+}$; found: 1526.6249.

Protected disaccharide(anh) tripeptide 42: Compound $\mathbf{4 2}$ was synthesized from 40 and 28 , and monosaccharide(anh) tetrapeptides 43 and $\mathbf{4 4}$ were synthesized from $\mathbf{3 4}$ and $\mathbf{3 0}$ (for $\mathbf{4 3}$ ) or $\mathbf{2 8}$ (for $\mathbf{4 4}$ ), in a manner similar to the synthesis of $\mathbf{4 1}$

Compound 42: ${ }^{1} \mathrm{H}$ NMR $\left(500 \mathrm{MHz}, \mathrm{CDCl}_{3}\right): \delta=7.82(1 \mathrm{H}, \mathrm{d}, J=6.5 \mathrm{~Hz}$; $\mathrm{NH}), 7.42-7.27(30 \mathrm{H}, \mathrm{m} ; \mathrm{Ar} H \times 6), 6.94(1 \mathrm{H}, \mathrm{d}, J=9.5 \mathrm{~Hz} ; \mathrm{NH}), 5.72$ $(1 \mathrm{H}, \mathrm{d}, J=8 \mathrm{~Hz} ; \mathrm{NH}), 5.59\left(1 \mathrm{H}, \mathrm{s} ; \mathrm{Ph}-\mathrm{C} H=\mathrm{O}_{2}\right), 5.30\left(1 \mathrm{H}, \mathrm{s} ; \mathrm{H}_{\mathrm{anh}}-1\right)$, $5.15-5.05\left(8 \mathrm{H}, \mathrm{m} ;-{ }^{\mathrm{COO}}-\mathrm{CH}_{2}-\mathrm{Ph} \times 4\right), 4.91\left(1 \mathrm{H}, \mathrm{d}, J=12.5 \mathrm{~Hz} ;-\mathrm{O}^{-}\right.$ $\left.\mathrm{CH}_{2}-\mathrm{Ph}\right), 4.68\left(1 \mathrm{H}, \mathrm{d}, J=12.5 \mathrm{~Hz} ;-\mathrm{O}-\mathrm{CH}_{2}-\mathrm{Ph}\right), 4.47(1 \mathrm{H}, \mathrm{td}, J=8$ $5 \mathrm{~Hz}$; DAP 2-H), 4.43-4.40 (2 H, m; $\left.\mathrm{H}_{\mathrm{anh}}-5, \mathrm{H}-1\right)$, 4.35-4.25 (4 H, m; H-6, Glu- $\alpha \mathrm{H}, \mathrm{Lac}-\alpha \mathrm{H}$, DAP $6-\mathrm{H}), 4.22\left(1 \mathrm{H}, \mathrm{d}, J=7.5 \mathrm{~Hz} ; \mathrm{H}_{\mathrm{anh}}-6\right), 4.10-4.06$ $\left(2 \mathrm{H}, \mathrm{m} ; \mathrm{H}_{\mathrm{anh}}-2\right.$, Ala- $\left.\alpha \mathrm{H}\right), 4.00(1 \mathrm{H}, \mathrm{q}, J=9 \mathrm{~Hz} ; \mathrm{H}-2), 3.81-3.68(4 \mathrm{H}, \mathrm{m}$; H-6', H-4, $\left.\mathrm{H}_{\text {anh }}-6^{\prime}, \mathrm{H}_{\mathrm{anh}^{-}}-4\right), 3.54(1 \mathrm{H}, \mathrm{t}, J=9.5 \mathrm{~Hz} ; \mathrm{H}-3), 3.46\left(1 \mathrm{H}, \mathrm{s} ; \mathrm{H}_{\mathrm{anh}^{-}}\right.$ 3), 3.40-3.35 (1 H, m; H-5), 2.30-2.12 (4 H, m; Glu- $\gamma \mathrm{CH}_{2}$, Glu- $\left.\beta \mathrm{CH}_{2}\right)$, $2.09\left(3 \mathrm{H}, \mathrm{s}\right.$; NHAc), $1.91\left(3 \mathrm{H}, \mathrm{s}\right.$; NHAc), 1.86-1.62 (4 H, m; DAP 3- $\mathrm{CH}_{2}$ DAP 5- $\left.\mathrm{CH}_{2}\right), 1.44-1.39\left(2 \mathrm{H}, \mathrm{m}\right.$; DAP $\left.4-\mathrm{CH}_{2}\right), 1.33(3 \mathrm{H}, \mathrm{d}, J=7 \mathrm{~Hz} ; \mathrm{Lac}-$ $\left.\beta_{\mathrm{CH}_{3}}\right), 1.29 \mathrm{ppm}\left(3 \mathrm{H}, \mathrm{d}, J=6.5 \mathrm{~Hz}\right.$; Ala- $\beta_{\mathrm{CH}}$ ); ESI-TOF-MS (positive): $m / z: 1434.11[M+\mathrm{H}]^{+}$

Disaccharide(anh) tetrapeptide (TCT, tracheal cytotoxin; 5): $\mathrm{Pd}(\mathrm{OH})_{2}$ $(20 \mathrm{mg})$ was added to a solution of $\mathbf{4 1}\left(5.3 \mathrm{mg}, 3.52 \times 10^{-6} \mathrm{~mol}\right)$ in THF $(300 \mu \mathrm{L})$. The reaction mixture was stirred for 1 day under a $\mathrm{H}_{2}$ atmosphere $\left(20 \mathrm{~kg} \mathrm{~cm}^{-2}\right)$. After this time, the $\mathrm{Pd}(\mathrm{OH})_{2}$ was removed by membrane filtration, and the filtrate was concentrated in vacuo to give 5 (3.2 mg, quant.). ESI-TOF-MS (positive): $m / z: 920.4[M-\mathrm{H}]^{-}$; HRMSESI QTOF-MS (positive): $m / z$ : calcd for $\mathrm{C}_{29} \mathrm{H}_{48} \mathrm{~N}_{6} \mathrm{O}_{16}: 922.3893[M+\mathrm{H}]^{+}$; found: 922.3898

Disaccharide(anh) tripeptide 6 and monosaccharide(anh) tetrapeptides 7 and 8: Compounds 6,7 , and 8 were synthesized from 42,43 , and 44 , respectively, in a manner similar to the synthesis of $\mathbf{5}$. 
Compound 6: ${ }^{1} \mathrm{H}$ NMR $\left(500 \mathrm{MHz}, \mathrm{CD}_{3} \mathrm{OH}\right): \delta=5.32\left(1 \mathrm{H}, \mathrm{s} ; \mathrm{H}_{\mathrm{anh}}-1\right)$, $4.62(1 \mathrm{H}, \mathrm{d}, J=5.5 \mathrm{~Hz} ; \mathrm{H}-6), 4.51\left(1 \mathrm{H}, \mathrm{d}, J=8.5 \mathrm{~Hz} ; \mathrm{H}-6^{\prime}\right), 4.47-4.42$ $(1 \mathrm{H}, \mathrm{m}$; Lac- $\alpha \mathrm{H}), 4.40-4.37(2 \mathrm{H}, \mathrm{m}$; Glu- $\alpha \mathrm{H}$, DAP $2-\mathrm{H}), 4.30(1 \mathrm{H}, \mathrm{d}$, $J=7 \mathrm{~Hz} ; \mathrm{H}-1), 4.12(1 \mathrm{H}, \mathrm{q}, J=6.5 \mathrm{~Hz}$; Ala- $\alpha \mathrm{H}), 3.98\left(1 \mathrm{H}, \mathrm{s} ; \mathrm{H}_{\mathrm{anh}}-2\right)$, 3.91- 3.86 (2H, m; $\left.\mathrm{H}_{\mathrm{anh}}-4, \mathrm{H}_{\mathrm{anh}}-5\right), 3.79-3.72$ (3H, m; H-2, H-5, DAP 6$\left.\mathrm{CH}_{2}\right), 3.71-3.68\left(1 \mathrm{H}, \mathrm{m} ; \mathrm{H}_{\mathrm{anh}}-6\right), 3.55\left(1 \mathrm{H}\right.$, brs; $\left.\mathrm{H}_{\mathrm{anh}}-3\right), 3.47-3.44(1 \mathrm{H}$, $\mathrm{m}$; H-4), 3.36-3.34 (1 H, m; $\left.\mathrm{H}_{\text {anh }}-6\right), 3.32-3.30$ (1 H, m; H-3), 2.38-2.33 $\left(2 \mathrm{H}, \mathrm{m}\right.$; Glu- $\left.\gamma \mathrm{CH}_{2}\right), 2.23-2.15\left(1 \mathrm{H}, \mathrm{m}\right.$; Glu- $\left.\beta_{\mathrm{CH}}\right), 2.07(3 \mathrm{H}, \mathrm{s} ; \mathrm{NHAc})$, 2.03 (3 H, s; NHAc), 1.99-1.92 (1 H, m; Glu- $\left.\beta \mathrm{CH}_{2}\right), 1.87-1.71(4 \mathrm{H}, \mathrm{m}$; DAP 3- $\mathrm{CH}_{2}$, DAP 5- $\left.\mathrm{CH}_{2}\right), 1.57-1.54\left(2 \mathrm{H}, \mathrm{m}\right.$; DAP 4- $\left.\mathrm{CH}_{2}\right), 1.42-$ $1.36 \mathrm{ppm}\left(6 \mathrm{H}, \mathrm{m}\right.$; Lac- $\beta \mathrm{CH}_{3}$, Ala- $\left.\beta \mathrm{CH}_{3}\right)$; HRMS-ESI QTOF-MS (positive): $m / z$ : calcd for $\mathrm{C}_{29} \mathrm{H}_{48} \mathrm{~N}_{6} \mathrm{O}_{16}: 851.3522[M+\mathrm{H}]^{+}$; found: 851.3531 .

1-Propenyl-2-acetylamino-4,6-O-benzylidene-2-deoxy-3- $O$ - $[(R)$-1-(ethoxycarbonyl)ethyl]- $\alpha$-D-glucopyranoside (46): $\mathrm{H}_{2}$ activated $[\operatorname{Ir}(\operatorname{cod})-$ $\left.\left(\mathrm{MePh}_{2} \mathrm{P}\right)_{2}\right] \mathrm{PF}_{6}(38 \mathrm{mg}, 0.0445 \mathrm{mmol})$ in dry THF $(2 \mathrm{~mL})$ was added to a solution of $45(200 \mathrm{mg}, 0.445 \mathrm{mmol})$ in dry THF $(2 \mathrm{~mL})$. After the reaction mixture had been stirred under an Ar atmosphere at RT for $45 \mathrm{~min}$, it was extracted with AcOEt. The organic layer was washed with saturated aqueous $\mathrm{NaHCO}_{3}$ and brine, dried over $\mathrm{Na}_{2} \mathrm{SO}_{4}$, and then concentrated in vacuo. The residue was purified by silica-gel flash column chromatography $\left(\mathrm{CHCl}_{3} /\right.$ acetone 50:1) to give 46 (182 $\left.\mathrm{mg}, 91 \%\right)$. ESI-TOF-MS (positive): $m / z: 450.2[\mathrm{M}+\mathrm{H}]^{+} ;{ }^{1} \mathrm{H} \mathrm{NMR}\left(500 \mathrm{MHz}, \mathrm{CDCl}_{3}\right): \delta=7.47-$ $7.36(5 \mathrm{H}, \mathrm{m} ; \mathrm{ArH}), 6.10\left(1 \mathrm{H}, \mathrm{dd}, J=12,1.7 \mathrm{~Hz} ;-\mathrm{O}-\mathrm{CH}=\mathrm{CH}^{-}\right), 5.59$ $\left(1 \mathrm{H}, \mathrm{s} ; \mathrm{Ph}-\mathrm{CH}=\mathrm{O}_{2}\right), 5.52(1 \mathrm{H}, \mathrm{d}, J=3 \mathrm{~Hz} ; \mathrm{H}-1), 5.14-5.07(1 \mathrm{H}, \mathrm{m}, J=$ $7 \mathrm{~Hz} ;-\mathrm{O}-\mathrm{CH}=\mathrm{CH}-), 4.51(1 \mathrm{H}, \mathrm{q}, J=7 \mathrm{~Hz} ; \mathrm{Lac}-\alpha \mathrm{H}), 4.28-4.15(4 \mathrm{H}, \mathrm{m}$; H-4, H-6, $-\mathrm{COOCH}_{2} \mathrm{CH}_{3}$ ), 3.89-3.68 (4 H, m; H-2, H-3, H-5, H-6'), 2.05 $(3 \mathrm{H}, \mathrm{s} ; \mathrm{NHAc}), 1.54\left(3 \mathrm{H}, \mathrm{dd}, J=7,1.5 \mathrm{~Hz} ;-\mathrm{CH}=\mathrm{CH}-\mathrm{CH}_{3}\right), 1.43(3 \mathrm{H}$, $\mathrm{d}, J=7 \mathrm{~Hz}$; $\left.\mathrm{Lac}-\mathrm{BCH}_{3}\right), 1.29\left(3 \mathrm{H}, \mathrm{t}, J=7 \mathrm{~Hz} ;-\mathrm{COOCH}_{2} \mathrm{CH}_{3}\right)$.

1-Propenyl-2-acetylamino-4,6-O-benzylidene-2-deoxy-3-O-[(R)-1-(carbonyloxy)ethyl]- $\boldsymbol{\alpha}$-D-glucopyranoside (47): Compound $\mathbf{4 6} \quad(93.9 \mathrm{mg}$, $0.209 \mathrm{mmol})$ was dissolved in $\mathrm{THF} / 1,4$-dioxane $/ \mathrm{H}_{2} \mathrm{O} \quad 2: 1: 0.5$ (2.1 $\left.\mathrm{mL}\right)$. $\mathrm{LiOH} \cdot \mathrm{H}_{2} \mathrm{O}(10 \mathrm{mg})$ was added to the solution and the resulting reaction mixture was stirred for $1 \mathrm{~h}$. After this time, the reaction was quenched with Dowex $\mathrm{H}^{+}$, which was subsequently removed by filtration. The mixture was then concentrated in vacuo and the resulting residue was purified by silica-gel flash column chromatography $\left(\mathrm{CHCl}_{3} / \mathrm{MeOH} 10: 1\right)$ to give 47 (90 mg, quant.).

Protected monosaccharide tetrapeptide 48 and protected monosaccharide tripeptide 49: Compounds 48 and 49 were synthesized from 47 and 30 (for $\mathbf{4 8}$ ) or $\mathbf{2 8}$ (for 49), in a manner similar to the synthesis of $\mathbf{4 1}$.

Compound 48: ${ }^{1} \mathrm{H} \mathrm{NMR}\left(500 \mathrm{MHz}, \mathrm{CDCl}_{3}\right): \delta=7.46-7.23(10 \mathrm{H}, \mathrm{m}$; $\mathrm{ArH}), 5.56-5.54\left(2 \mathrm{H}\right.$, brs; $\left.\mathrm{Ph}-\mathrm{CH}=\mathrm{O}_{2} ; \mathrm{H}-1\right), 5.17-5.03(9 \mathrm{H}, \mathrm{m} ;-\mathrm{O}-$ $\left.\mathrm{CH}=\mathrm{CH}-,-\mathrm{CH}_{2}-\mathrm{Ph} \times 4\right), 4.56-4.06(9 \mathrm{H}, \mathrm{m}$; Glu- $\alpha \mathrm{H}, \mathrm{Lac}-\alpha \mathrm{H}$, DAP 2-H, DAP 4-H, Ala- $\alpha \mathrm{H}, \mathrm{D}-\mathrm{Ala}-\alpha \mathrm{H}, \mathrm{H}-5, \mathrm{H}-2,-\mathrm{O}-\mathrm{CH}=\mathrm{CH}-), 3.87-3.60(4 \mathrm{H}$, m; H-4, H-3, H-6, H-6'), 2.17-1.81 (4 H, m; Glu- $\beta \mathrm{CH}_{2}$, Glu- $\left.\gamma \mathrm{CH}_{2}\right), 1.89$ (3H, s; NHAc), 1.84-1.34 (11H, m; DAP 3- $\mathrm{CH}_{2}$, DAP 5- $\mathrm{CH}_{2}$, DAP $4-$ $\mathrm{CH}_{2}$, Lac- $\beta \mathrm{CH}_{3}$, Ala- $\beta \mathrm{H}$, D-Ala- $\left.\beta \mathrm{H}\right), 1.52 \mathrm{ppm}(3 \mathrm{H}, \mathrm{dd}, J=7,1.5 \mathrm{~Hz}$; $-\mathrm{O}-\mathrm{CH}=\mathrm{CH}-\mathrm{CH}_{3}$ ); ESI-TOF-MS (positive): $m / z: 1269.49[\mathrm{M+H}]^{+}$; HRMS-ESI QTOF-MS (positive): $\mathrm{m} / z$ : calcd for $\mathrm{C}_{68} \mathrm{H}_{80} \mathrm{~N}_{6} \mathrm{O}_{18}: 1291.5427$ $[M+\mathrm{Na}]^{+}$; found: 1291.5427 .

Compound 49: ${ }^{1} \mathrm{H} \mathrm{NMR}\left(500 \mathrm{MHz}, \mathrm{CDCl}_{3}\right): \delta=7.37-7.28(10 \mathrm{H}, \mathrm{m}$; $\mathrm{ArH}), 5.56\left(1 \mathrm{H}, \mathrm{s} ; \mathrm{Ph}-\mathrm{CH}=\mathrm{O}_{2}\right), 5.51(1 \mathrm{H}, \mathrm{d}, J=8 \mathrm{~Hz} ; \mathrm{H}-1), 5.12-5.08$ $(1 \mathrm{H}, \mathrm{m} ;-\mathrm{O}-\mathrm{CH}=\mathrm{CH}-), 5.12-4.38(4 \mathrm{H}, \mathrm{m} ; \mathrm{Glu}-\alpha \mathrm{H}, \mathrm{Lac}-\alpha \mathrm{H}$, DAP 2-H, DAP 4-H), 4.34-4.14 (5 H, m; H-6, H-2, H-4, $-\mathrm{O}-\mathrm{CH}=\mathrm{CH}-$, Ala- $\alpha \mathrm{H})$, 3.84-3.69 (2 H, m; H-5, H-6'), 2.28-2.06 (4 H, m; Glu- $\beta_{\mathrm{CH}}$, Glu- $\left.\gamma \mathrm{CH}_{2}\right)$, 1.89 (3H, s; NHAc), 1.83-1.59 (4 H, m; DAP 3- $\mathrm{CH}_{2}$, DAP 5- $\left.\mathrm{CH}_{2}\right), 1.52$ $\left(3 \mathrm{H}, \mathrm{dd}, J=7,1.5 \mathrm{~Hz} ;-\mathrm{O}-\mathrm{CH}=\mathrm{CH}-\mathrm{CH}_{3}\right), 1.40-1.38(2 \mathrm{H}, \mathrm{m}$; DAP $4-$ $\left.\mathrm{CH}_{2}\right), 1.38\left(3 \mathrm{H}, \mathrm{d}, J=7 \mathrm{~Hz}\right.$; Lac- $\left.\beta \mathrm{CH}_{3}\right), 1.35(3 \mathrm{H}, \mathrm{d}, J=6.5 \mathrm{~Hz}$; Ala$\beta \mathrm{H}$ ); ESI-TOF-MS (positive): $m / z: 1198.53[M+\mathrm{H}]^{+}$; HRMS-ESI QTOFMS (positive): $m / z$ : calcd for $\mathrm{C}_{65} \mathrm{H}_{75} \mathrm{~N}_{5} \mathrm{O}_{17}: 1220.5056[M+\mathrm{Na}]^{+}$; found: 1220.5055 .

1-O-Deprotected monosaccharide tetrapeptide 50: Compound 48 $\left(4.6 \mathrm{mg}, 3.62 \times 10^{-6} \mathrm{~mol}\right)$ was suspended in $\mathrm{THF} / \mathrm{H}_{2} \mathrm{O} 2: 1(360 \mu \mathrm{L}) . \mathrm{I}_{2}$ $\left(2 \mathrm{mg}, 7.25 \times 10^{-6} \mathrm{~mol}\right)$ was then added to the solution, and the reaction mixture was stirred for $30 \mathrm{~min}$. The reaction was quenched by $10 \%$ $\mathrm{Na}_{2} \mathrm{~S}_{2} \mathrm{O}_{4}$ aq. and the mixture was extracted with AcOEt. The organic layer was washed with $10 \% \mathrm{Na}_{2} \mathrm{~S}_{2} \mathrm{O}_{4}$ aq., saturated aqueous $\mathrm{NaHCO}_{3}$, and brine, dried over $\mathrm{Na}_{2} \mathrm{SO}_{4}$, and concentrated in vacuo. The residue was purified by silica-gel flash column chromatography $\left(\mathrm{CHCl}_{3} / \mathrm{MeOH}\right.$ $30: 1)$ to give 50 (4.6 mg, quant.). ${ }^{1} \mathrm{H}$ NMR $\left(500 \mathrm{MHz}, \mathrm{CDCl}_{3}\right): \delta=7.39$ $7.27(20 \mathrm{H}, \mathrm{m} ; \mathrm{ArH}), 5.56\left(1 \mathrm{H}, \mathrm{s} ; \mathrm{Ph}-\mathrm{CH}=\mathrm{O}_{2}\right), 5.26(1 \mathrm{H}, \mathrm{d}, J=3 \mathrm{~Hz} ; \mathrm{H}-$ 1), 5.17-5.04 $\left(8 \mathrm{H}, \mathrm{m} ;-\mathrm{COO}-\mathrm{CH}_{2}-\mathrm{Ph} \times 4\right), 4.51-4.19(7 \mathrm{H}, \mathrm{m}$; Glu- $\alpha \mathrm{H}$ DAP 2-H, DAP 6-H, Lac- $\alpha \mathrm{H}$, Ala- $\alpha \mathrm{H}$, D-Ala- $\alpha \mathrm{H}, \mathrm{H}-4, \mathrm{H}-2), 4.14-4.11$ (1 H, m; H-2), 3.79-3.63 (3 H, m; H-6, H-6', H-3), 3.41-3.40 (1 H, m; H5), 2.35-1.79 (4 H, m; Glu- $\beta \mathrm{CH}_{2}$, Glu- $\left.\gamma \mathrm{CH}_{2}\right), 1.65-1.57$ (4 H, m; DAP $3-$ $\mathrm{CH}_{2}$, DAP 5- $\left.\mathrm{CH}_{2}\right), 1.95$ (3H, s; NHAc), $1.39-1.32 \mathrm{ppm}(8 \mathrm{H}, \mathrm{m}$; DAP $4-$ $\mathrm{CH}_{2}$, Lac- $\mathrm{\beta CH}_{3}$, Ala- $\beta \mathrm{CH}_{3}$ ); HRMS-ESI QTOF-MS (positive): $\mathrm{m} / \mathrm{z}$ calcd for $\mathrm{C}_{65} \mathrm{H}_{76} \mathrm{~N}_{6} \mathrm{O}_{18}: 1251.5114[M+\mathrm{Na}]^{+}$; found: 1251.5114 .

1-O-Deprotected monosaccharide tripeptide 51: Compound $49(5.6 \mathrm{mg}$, $\left.4.67 \times 10^{-6} \mathrm{~mol}\right)$ was suspended in $\mathrm{THF} / \mathrm{H}_{2} \mathrm{O} 2: 1(450 \mu \mathrm{L}) . \mathrm{I}_{2}(3 \mathrm{mg}, 9.35 \times$ $\left.10^{-6} \mathrm{~mol}\right)$ was added to the solution, and the reaction mixture was stirred for $30 \mathrm{~min}$. After this time, the reaction mixture was quenched by $10 \%$ $\mathrm{Na}_{2} \mathrm{~S}_{2} \mathrm{O}_{4}$ aq. and the mixture was extracted with AcOEt. The organic layer was washed with $10 \% \mathrm{Na}_{2} \mathrm{~S}_{2} \mathrm{O}_{4}$ aq., saturated aqueous $\mathrm{NaHCO}_{3}$, and brine, dried over $\mathrm{Na}_{2} \mathrm{SO}_{4}$, and concentrated in vacuo. The residue was purified by silica-gel flash column chromatography $\left(\mathrm{CHCl}_{3} / \mathrm{MeOH}\right.$ $30: 1)$ to give $\mathbf{5 1}(4.1 \mathrm{mg}, 76 \%)$. ${ }^{1} \mathrm{H}$ NMR $\left(500 \mathrm{MHz}, \mathrm{CDCl}_{3}\right): \delta=7.35$ $7.26(20 \mathrm{H}, \mathrm{m} ; \mathrm{ArH}), 5.56\left(1 \mathrm{H}, \mathrm{s} ; \mathrm{Ph}-\mathrm{CH}=\mathrm{O}_{2}\right), 5.34(1 \mathrm{H}, \mathrm{s} ; \mathrm{H}-1), 5.18$ $5.05\left(8 \mathrm{H}, \mathrm{m} ;-\mathrm{COO}-\mathrm{CH}_{2}-\mathrm{Ph} \times 4\right), 4.51-4.15(7 \mathrm{H}, \mathrm{m}$; Glu- $\alpha \mathrm{H}$, DAP $2-\mathrm{H}$ DAP 6-H, Lac- $\alpha \mathrm{H}$, Ala- $\alpha \mathrm{H}, \mathrm{H}-4, \mathrm{H}-2), 3.82-3.61$ (3 H, m; H-6, H-6', H3), 3.44-3.41 (1 H, m; H-5), 2.35-1.66 (8H, m; Glu- $\beta_{\mathrm{CH}}$, Glu- $\gamma \mathrm{CH}_{2}$ DAP $3-\mathrm{CH}_{2}$, DAP $4-\mathrm{CH}_{2}$, DAP $\left.5-\mathrm{CH}_{2}\right), 1.95(3 \mathrm{H}, \mathrm{s} ; \mathrm{NHAc}), 1.38$ $1.32 \mathrm{ppm}\left(6 \mathrm{H}, \mathrm{m}\right.$; Lac- $\beta_{\mathrm{CH}}$, Ala- $\beta \mathrm{CH}_{3}$ ); ESI-TOF-MS (positive): $\mathrm{m} / \mathrm{z}$ : $1158.50[M+\mathrm{H}]^{+}$; HRMS-ESI QTOF-MS (positive): $\mathrm{m} / \mathrm{z}$ : calcd for $\mathrm{C}_{62} \mathrm{H}_{71} \mathrm{~N}_{5} \mathrm{O}_{17}$ : $1180.4743[M+\mathrm{Na}]^{+}$; found: 1180.4746 .

Monosaccharide tetrapeptide 3 and monosaccharide tripeptide 4: Compounds $\mathbf{3}$ and $\mathbf{4}$ were synthesized from $\mathbf{5 0}$ and 51, respectively, in a manner similar to the synthesis of $\mathbf{5}$.

Compound 3: ${ }^{1} \mathrm{H}$ NMR $\left(500 \mathrm{MHz}, \mathrm{CDCl}_{3}\right): \delta=5.10(1 \mathrm{H}, \mathrm{d}, J=4 \mathrm{~Hz} ; \mathrm{H}-$ 1), 4.27-4.19 (5 H, m; Glu- $\alpha \mathrm{H}$, DAP 2-H, Ala- $\alpha \mathrm{H}$, D-Ala- $\alpha \mathrm{H}$, Lac- $\alpha \mathrm{H})$, $3.90(1 \mathrm{H}, \mathrm{dd}, J=3.5,11 \mathrm{~Hz} ; \mathrm{H}-2), 3.83-3.80(1 \mathrm{H}, \mathrm{m} ; \mathrm{H}-5), 3.77-3.67$ $(3 \mathrm{H}, \mathrm{m} ; \mathrm{DAP}-\alpha \mathrm{H}, \mathrm{H}-6, \mathrm{H}-3), 3.53-3.45$ (2 H, m; H-4, H-6'), 2.30-2.27 $\left(2 \mathrm{H}, \mathrm{m}\right.$; Glu- $\left.\gamma \mathrm{CH}_{2}\right), 2.14-1.69\left(8 \mathrm{H}, \mathrm{m}\right.$; Glu- $\beta_{\mathrm{CH}}$, DAP 3- $\left.\mathrm{CH}_{2}, 5-\mathrm{CH}_{2}\right)$, $1.92(3 \mathrm{H}, \mathrm{s} ; \mathrm{NHAc}), 1.43-1.39\left(2 \mathrm{H}, \mathrm{m} ; \mathrm{DAP} 4-\mathrm{CH}_{2}\right), 1.37(3 \mathrm{H}, \mathrm{d}, J=$ $7 \mathrm{~Hz}$; Lac- $\beta \mathrm{H}), 1.34-1.30$ ppm $(6 \mathrm{H}, \mathrm{m}$; Ala- $\beta \mathrm{H}$, D-Ala- $\beta \mathrm{H})$; ESI-TOFMS (negative): $m / z: 735.30[M+\mathrm{H}]^{-}$; HRMS-ESI QTOF-MS (positive): $m / z$ : calcd for $\mathrm{C}_{29} \mathrm{H}_{48} \mathrm{~N}_{6} \mathrm{O}_{16}: 737.3205[M+\mathrm{Na}]^{+}$; found: 737.3209 .

Compound 4: ${ }^{1} \mathrm{H} \mathrm{NMR}\left(500 \mathrm{MHz}, \mathrm{CDCl}_{3}\right): \delta=5.10(1 \mathrm{H}, \mathrm{d}, J=3.5 \mathrm{~Hz}$; $\mathrm{H}-1), 4.28-4.21$ (4 H, m; Glu- $\alpha \mathrm{H}, \mathrm{DAP}-\alpha \mathrm{H}$, Ala- $\alpha \mathrm{H}, \mathrm{Lac}-\alpha \mathrm{H}), 3.90(1 \mathrm{H}$ $\mathrm{dd}, J=3.5,10.5 \mathrm{~Hz} ; \mathrm{H}-2), 3.85-3.79(1 \mathrm{H}, \mathrm{m} ; \mathrm{H}-5), 3.77-3.70(1 \mathrm{H}, \mathrm{m}$; DAP- $\alpha \mathrm{H}, \mathrm{H}-6), 3.63(1 \mathrm{H}, \mathrm{d}, J=10.5 \mathrm{~Hz} ; \mathrm{H}-3), 3.53-3.45(2 \mathrm{H}, \mathrm{m} ; \mathrm{H}-4, \mathrm{H}-$ $\left.6^{\prime}\right), 2.32-2.21\left(2 \mathrm{H}, \mathrm{m}\right.$; Glu- $\left.\gamma \mathrm{CH}_{2}\right), 2.18-1.67\left(6 \mathrm{H}, \mathrm{m}\right.$; Glu- $\beta \mathrm{CH}_{2}$, DAP $3-$ $\left.\mathrm{CH}_{2}, 5-\mathrm{CH}_{2}\right), 1.92(3 \mathrm{H}, \mathrm{s} ; \mathrm{NHAc}), 1.43-1.40\left(2 \mathrm{H}, \mathrm{m} ; \mathrm{DAP} 4-\mathrm{CH}_{2}\right), 1.36$ $(3 \mathrm{H}, \mathrm{d}, J=7.5 \mathrm{~Hz}$; Lac- $\beta \mathrm{H}), 1.32 \mathrm{ppm}(3 \mathrm{H}, \mathrm{d}, J=6.5 \mathrm{~Hz}$; Ala- $\beta \mathrm{H})$; ESITOF-MS (negative): $m / z: 664.26[M-\mathrm{H}]^{-}$; HRMS-ESI QTOF-MS (positive): $m / z$ : calcd for $\mathrm{C}_{26} \mathrm{H}_{43} \mathrm{~N}_{5} \mathrm{O}_{15}: 666.2834[M+\mathrm{Na}]^{+}$; found: 666.2837 .

1-Allyl 2-acetylamino-6-O-benzyl-4- $O$ - $\left(2^{\prime}\right.$-acetylamino-3'-O-benzyl-4', $\mathbf{6}^{\prime}$ $O$-benzylidene-2'-deoxy- $\beta$-D-glucopyranosyl)-2-deoxy-3- $O$ - $[(R)-1$-(ethoxycarbonyl)ethyl]- $\alpha$-D-glucopyranoside (53): $\mathrm{Zn} / \mathrm{Cu}$ (three microspatula spoonfuls) was added to a solution of $\mathbf{5 2}(200 \mathrm{mg}, 0.182 \mathrm{mmol})$ in THF/ $\mathrm{AcOH} / \mathrm{Ac}_{2} \mathrm{O}$ 1:1:1 (2 mL), and the mixture was stirred at RT for $3.5 \mathrm{~h}$ After this time, the insoluble materials were filtered off and the filtrate was concentrated in vacuo. The residue was extracted with AcOEt and the organic layer was washed with saturated aqueous $\mathrm{NaHCO}_{3}$ and brine, dried over $\mathrm{Na}_{2} \mathrm{SO}_{4}$, and concentrated in vacuo. The residue was purified by silica-gel flash column chromatography (toluene/AcOEt 2:1) to give 53 (69 mg, 46\%). ${ }^{1} \mathrm{H}$ NMR $\left(500 \mathrm{MHz}, \mathrm{CDCl}_{3}\right): \delta=7.44-7.28(15 \mathrm{H}, \mathrm{m}$; $\mathrm{ArH}), 5.88-5.81\left(1 \mathrm{H}, \mathrm{m} ;-\mathrm{O}-\mathrm{CH}_{2}-\mathrm{CH}=\mathrm{CH}_{2}\right), 5.58\left(1 \mathrm{H}, \mathrm{s} ; \mathrm{Ph}-\mathrm{CH}-\mathrm{O}_{2}\right)$, $5.31-5.30(1 \mathrm{H}, \mathrm{d}, J=3 \mathrm{~Hz} ; \mathrm{H}-1), 5.25-5.22(1 \mathrm{H}, \mathrm{dd}, J=1.5,17 \mathrm{~Hz} ;-\mathrm{O}-$ $\left.\mathrm{CH}_{2}-\mathrm{CH}=\mathrm{CH}_{\text {trans }} \mathrm{H}_{\text {cis }}\right), 5.16-5.13\left(1 \mathrm{H}, \mathrm{dd}, J=1.5,10 \mathrm{~Hz} ;-\mathrm{O}-\mathrm{CH}_{2}-\mathrm{CH}=\right.$ $\left.\mathrm{CH}_{\text {trans }} H_{\text {cis }}\right), 4.88\left(1 \mathrm{H}, \mathrm{d}, J=12 \mathrm{~Hz} ; \mathrm{Ph}-\mathrm{CH}_{2}-\mathrm{O}-\right), 4.83(1 \mathrm{H}, \mathrm{d}, J=12 \mathrm{~Hz}$ $\left.\mathrm{Ph}-\mathrm{CH}_{2}-\mathrm{O}-\right), 4.65\left(1 \mathrm{H}, \mathrm{d}, J=12 \mathrm{~Hz} ; \mathrm{Ph}-\mathrm{CH}_{2}-\mathrm{O}-\right), 4.35(1 \mathrm{H}, \mathrm{d}, J=$ $\left.12 \mathrm{~Hz} ; \mathrm{Ph}-\mathrm{CH}_{2}-\mathrm{O}-\right), 4.62-4.60(1 \mathrm{H}, \mathrm{m} ; \mathrm{Lac}-\alpha \mathrm{H}), 4.45-4.39(2 \mathrm{H}, \mathrm{m} ; \mathrm{H}-$ $\left.1^{\prime}, \mathrm{H}-6^{\prime}\right)$, 4.26-4.11 (3H, m; $\left.-\mathrm{COOCH}_{2} \mathrm{CH}_{3}, \mathrm{H}-6\right), 3.97-3.92(2 \mathrm{H}, \mathrm{m}$; $\left.-\mathrm{O}-\mathrm{CH}-\mathrm{CH}=\mathrm{CH}_{2}\right), 3.78-3.74\left(4 \mathrm{H}, \mathrm{m} ; \mathrm{H}-2, \mathrm{H}-2^{\prime}, \mathrm{H}-4^{\prime}, \mathrm{H}-6^{\prime}\right), 3.69-3.44$ $\left(6 \mathrm{H}, \mathrm{m} ; \mathrm{H}-4^{\prime}, \mathrm{H}-5, \mathrm{H}-6, \mathrm{H}-3, \mathrm{H}-3^{\prime}, \mathrm{H}-4\right), 3.32-3.27$ (1 H, m; H-5'), 2.00 
$\left(3 \mathrm{H}, \mathrm{s}\right.$; NHAc), $1.74\left(3 \mathrm{H}, \mathrm{s}\right.$; NHAc), $1.35\left(3 \mathrm{H}, \mathrm{d}, J=7 \mathrm{~Hz}\right.$; Lac- $\left.\beta \mathrm{CH}_{3}\right)$, $1.30\left(3 \mathrm{H}, \mathrm{t}, J=7 \mathrm{~Hz} ;-\mathrm{COOCH}_{2} \mathrm{CH}_{3}\right)$; ESI-TOF-MS (positive): $\mathrm{m} / z$ : $833.44[M+\mathrm{H}]^{+}$

1-Propenyl 2-acetylamino-6-O-benzyl-4-O-(2'-acetylamino-3'-O-benzyl$4^{\prime}, 6^{\prime}$-O -benzylidene-2'-deoxy- $\beta$-D-glucopyranosyl)-2-deoxy-3- $O$ - $[(R)-1-$ (ethoxycarbonyl)ethyl]- $\alpha$-D-glucopyranoside (54): $\mathrm{H}_{2}$ activated $[\operatorname{Ir}(\operatorname{cod})$ $\left.\left(\mathrm{MePh}_{2} \mathrm{P}\right)_{2}\right] \mathrm{PF}_{6}\left(6.2 \mathrm{mg}, 7.31 \times 10^{-6} \mathrm{~mol}\right)$ in dry THF $(500 \mu \mathrm{L})$ was added to a solution of $\mathbf{5 3}(60.9 \mathrm{mg}, 0.0731 \mathrm{mmol})$ in dry THF $(500 \mu \mathrm{L})$. After the reaction mixture had been stirred under an Ar atmosphere at RT for $2.5 \mathrm{~h}$, the reaction mixture was extracted with AcOEt. The organic layer was washed with saturated aqueous $\mathrm{NaHCO}_{3}$ and brine, dried over $\mathrm{Na}_{2} \mathrm{SO}_{4}$, and concentrated in vacuo. The residue was purified by silica-gel flash column chromatography $\left(\mathrm{CHCl}_{3} /\right.$ acetone $\left.15: 1\right)$ to give $\mathbf{5 4}(48.6 \mathrm{mg}$, $80 \%) .{ }^{1} \mathrm{H}$ NMR $\left(500 \mathrm{MHz}, \mathrm{CDCl}_{3}\right): \delta=7.44-7.28(15 \mathrm{H}, \mathrm{m} ; \mathrm{Ar} H), 6.08$ $\left(1 \mathrm{H}, \mathrm{dd}, J=1.5,12 \mathrm{~Hz} ;{ }^{-} \mathrm{O}-\mathrm{CH}=\mathrm{CH}-\mathrm{CH}_{3}\right), 5.59\left(1 \mathrm{H}, \mathrm{s} ;-\mathrm{Ph}-\mathrm{CH}=\mathrm{O}_{2}\right)$, $5.50(1 \mathrm{H}, \mathrm{d}, J=3.5 \mathrm{~Hz} ; \mathrm{H}-1), 5.10-5.04\left(1 \mathrm{H}, \mathrm{m} ;-{ }^{-}-\mathrm{CH}=\mathrm{CH}-\mathrm{CH}_{3}\right), 4.88$ $\left(1 \mathrm{H}, \mathrm{d}, J=12 \mathrm{~Hz} ; \mathrm{Ph}^{-} \mathrm{CH}_{2}-\mathrm{O}^{-}\right), 4.83\left(1 \mathrm{H}, \mathrm{d}, J=12 \mathrm{~Hz} ; \mathrm{Ph}^{-} \mathrm{CH}_{2}-\mathrm{O}^{-}\right)$, $4.65\left(1 \mathrm{H}, \mathrm{d}, J=12 \mathrm{~Hz} ; \mathrm{Ph}-\mathrm{CH}_{2}-\mathrm{O}-\right), 4.64-4.60(1 \mathrm{H}, \mathrm{m} ; \mathrm{Lac}-\alpha \mathrm{H}), 4.44-$ $\left.4.40\left(2 \mathrm{H}, \mathrm{m} ; \mathrm{H}-1^{\prime}, \mathrm{H}-6^{\prime}\right), 4.26-4.13\left(3 \mathrm{H}, \mathrm{m} ;-\mathrm{COOCH}_{2} \mathrm{CH}_{3}\right), \mathrm{H}-6\right), 3.96$ $(1 \mathrm{H}, \mathrm{t}, J=9 \mathrm{~Hz} ; \mathrm{H}-2), 3.78-3.42\left(8 \mathrm{H}, \mathrm{m} ; \mathrm{H}-3, \mathrm{H}-4, \mathrm{H}-5, \mathrm{H}-6, \mathrm{H}-2^{\prime}, \mathrm{H}-3^{\prime}\right.$, H-4', H-6'), 3.32-3.27 (1 H, m; H-5'), $1.20(3 \mathrm{H}, \mathrm{s}$; NHAc), $1.73(3 \mathrm{H}, \mathrm{s}$; NHAc), $1.54\left(3 \mathrm{H}, \mathrm{s} ;-\mathrm{O}-\mathrm{CH}=\mathrm{CH}-\mathrm{CH}_{3}\right), 1.36(3 \mathrm{H}, \mathrm{d}, J=7 \mathrm{~Hz}$; Lac$\left.\mathrm{\beta CH}_{3}\right), 1.30\left(3 \mathrm{H}, \mathrm{t}, \mathrm{J}=7 \mathrm{~Hz} ;-\mathrm{COOCH}_{2} \mathrm{CH}_{3}\right)$; ESI-TOF-MS (positive): $m / z: 833.4[M+\mathrm{H}]^{+}$

1-Propenyl 2-acetylamino-6- $O$-benzyl-4- $O$-(2'-acetylamino-3'-O-benzyl4',6'-O-benzylidene-2'-deoxy- $\beta$-D-glucopyranosyl)-3- $O$ - $[(R)$-1-(carbonyloxy)ethyl]-2-deoxy- $\alpha$-D-glucopyranoside (55): Compound $\mathbf{5 4}(48.6 \mathrm{mg}$, $\left.5.83 \times 10^{-5} \mathrm{~mol}\right)$ was dissolved in $\mathrm{THF} / 1,4-$ dioxane $/ \mathrm{H}_{2} \mathrm{O}$ 2:1:0.5 $(700 \mu \mathrm{L})$. $\mathrm{LiOH} \cdot \mathrm{H}_{2} \mathrm{O}\left(3 \mathrm{mg}, 6.42 \times 10^{-5} \mathrm{~mol}\right)$ was added to the solution and the reaction mixture was stirred for $3 \mathrm{~h}$. After this time, the reaction was quenched with Dowex $\mathrm{H}^{+}$, which was subsequently removed by filtration. The mixture was then concentrated in vacuo and the resulting residue was applied to an HP-20 column $(2 \times 7 \mathrm{~cm})$. Organic and inorganic salts were removed by elution with $\mathrm{H}_{2} \mathrm{O}$, followed by elution with $\mathrm{MeOH}$ to give $\mathbf{5 5}(41.7 \mathrm{mg}, 91 \%)$

Protected disaccharide tetrapeptide 56 and protected disaccharide tripeptide 57: Compounds 56 and $\mathbf{5 7}$ were synthesized from 55 and $\mathbf{3 0}$ (for 56) or $\mathbf{2 8}$ (for 57), respectively, in a manner similar to the synthesis of $\mathbf{4 1}$.

Compound 56: ${ }^{1} \mathrm{H}$ NMR $\left(500 \mathrm{MHz}, \mathrm{CDCl}_{3}\right): \delta=7.40-7.24(35 \mathrm{H}, \mathrm{m}$; $\mathrm{Ar} H), 6.06\left(1 \mathrm{H}, \mathrm{d}, J=12.5 \mathrm{~Hz} ;-{ }^{-} \mathrm{O}-\mathrm{CH}=\mathrm{CH}-\mathrm{CH}_{3}\right), 5.58(1 \mathrm{H}, \mathrm{s} ; \mathrm{Ph}-$ $\left.\mathrm{C} H=\mathrm{O}_{2}\right), 5.27(1 \mathrm{H}, \mathrm{s} ; \mathrm{H}-1), 5.15-5.02\left(10 \mathrm{H}, \mathrm{m} ;-{ }^{\mathrm{COO}}-\mathrm{CH}_{2}-\mathrm{Ph} \times 4\right.$, $\left.-\mathrm{O}-\mathrm{CH}=\mathrm{CH}-\mathrm{CH}_{3}, \mathrm{H}-1^{\prime}\right), 4.86\left(1 \mathrm{H}, \mathrm{d}, J=12 \mathrm{~Hz} ;-{ }^{-} \mathrm{O}-\mathrm{CH}_{2} \mathrm{Ph}\right), 4.75(1 \mathrm{H}$, d, $\left.J=12 \mathrm{~Hz} ;-\mathrm{O}-\mathrm{CH}_{2} \mathrm{Ph}\right), 4.65\left(1 \mathrm{H}, \mathrm{d}, J=12 \mathrm{~Hz} ;-\mathrm{O}-\mathrm{CH}_{2} \mathrm{Ph}\right), 4.58(1 \mathrm{H}$, brs; H-6), 4.52-4.30 (8H, m; Lac- $\alpha \mathrm{H}$, Ala- $\alpha \mathrm{H}$, D-Ala- $\alpha \mathrm{H}$, Glu- $\alpha \mathrm{H}$, DAP 2-H, DAP 6-H, H-6' $\times 2), 3.98\left(1 \mathrm{H}, \mathrm{t}, J=10 \mathrm{~Hz} ; \mathrm{H}-3^{\prime}\right), 3.92-3.90(1 \mathrm{H}, \mathrm{m}$; $\mathrm{H}-2), 3.76(1 \mathrm{H}, \mathrm{t}, J=10.5 \mathrm{~Hz} ; \mathrm{H}-4), 3.66-3.58\left(5 \mathrm{H}, \mathrm{m} ; \mathrm{H}-4^{\prime}, \mathrm{H}-3, \mathrm{H}-2^{\prime}\right.$, H-5, H-6), 3.31-3.26 (1 H, m; H-5), 2.31-2.11 (4H, m; Glu- $\beta \mathrm{CH}_{2}$, Glu$\left.\gamma \mathrm{CH}_{2}\right), 1.94(3 \mathrm{H}, \mathrm{s}$; NHAc), $1.80(3 \mathrm{H}, \mathrm{s}$; NHAc), $1.67-1.34(6 \mathrm{H}, \mathrm{m}$; DAP $3-\mathrm{CH}_{2}$, DAP $4-\mathrm{CH}_{2}$, DAP $\left.5-\mathrm{CH}_{2}\right), 1.48\left(3 \mathrm{H}, \mathrm{d}, J=6.5 \mathrm{~Hz} ;-\mathrm{O}^{-}\right.$ $\left.\mathrm{CH}=\mathrm{CH}-\mathrm{CH}_{3}\right), 1.38-1.34 \mathrm{ppm}\left(6 \mathrm{H}, \mathrm{m}\right.$; Lac- $\mathrm{\beta CH}_{3}$, Ala- $\left.\mathrm{\beta CH}_{3}\right)$; ESI-TOFMS (positive): $m / z: 1652.67[M+\mathrm{H}]^{+}$.

Compound 57: ${ }^{1} \mathrm{H}$ NMR $\left(500 \mathrm{MHz}, \mathrm{CDCl}_{3}\right): \delta=7.42-7.21(35 \mathrm{H}, \mathrm{m}$; $\operatorname{Ar} H), 6.06\left(1 \mathrm{H}, \mathrm{d}, J=12.5 \mathrm{~Hz} ;-\mathrm{O}-\mathrm{CH}=\mathrm{CH}-\mathrm{CH}_{3}\right), 5.58(1 \mathrm{H}, \mathrm{s} ; \mathrm{Ph}-$ $\left.\mathrm{C} H=\mathrm{O}_{2}\right), 5.28(1 \mathrm{H}, \mathrm{d}, J=3.5 \mathrm{~Hz} ; \mathrm{H}-1), 5.15-5.00\left(9 \mathrm{H}, \mathrm{m} ;-\mathrm{COO}-\mathrm{CH}_{2}-\right.$ $\left.\mathrm{Ph} \times 4,-\mathrm{O}-\mathrm{CH}=\mathrm{CH}-\mathrm{CH}_{3}\right), 4.86\left(1 \mathrm{H}, \mathrm{d}, J=12 \mathrm{~Hz} ;-\mathrm{O}-\mathrm{CH}_{2} \mathrm{Ph}\right), 4.73$ $\left(1 \mathrm{H}, \mathrm{d}, J=12 \mathrm{~Hz} ;-\mathrm{O}-\mathrm{CH}_{2} \mathrm{Ph}\right), 4.64\left(1 \mathrm{H}, \mathrm{d}, J=12 \mathrm{~Hz} ;-\mathrm{O}-\mathrm{CH}_{2} \mathrm{Ph}\right)$, 4.61-4.29 (5 H, m; Lac- $\alpha \mathrm{H}$, Ala- $\alpha \mathrm{H}$, Glu- $\alpha \mathrm{H}$, DAP 2-H, DAP 6-H), 3.97 $(1 \mathrm{H}, \mathrm{t}, J=9.5 \mathrm{~Hz} ; \mathrm{H}-5), 3.91(1 \mathrm{H}, \mathrm{dd}, J=2.5,10.5 \mathrm{~Hz} ; \mathrm{H}-2), 3.76(1 \mathrm{H}, \mathrm{t}$, $\left.J=10.5 \mathrm{~Hz} ; \mathrm{H}-6^{\prime}\right), 3.70-3.60\left(2 \mathrm{H}, \mathrm{m} ; \mathrm{H}-4, \mathrm{H}-4^{\prime}\right), 3.59-3.53(1 \mathrm{H}, \mathrm{m} ; \mathrm{H}-3)$, 3.31-3.26 (1 H, m; H-5'), 2.26-2.00 (4 H, m; Glu- $\beta^{\prime} \mathrm{CH}_{2}$, Glu- $\left.\gamma \mathrm{CH}_{2}\right), 1.94$ $\left(3 \mathrm{H}, \mathrm{s}\right.$; NHAc), 1.79 (3H, s; NHAc), $1.82-1.57\left(4 \mathrm{H}, \mathrm{m}\right.$; DAP $3-\mathrm{CH}_{2}$, DAP $\left.5-\mathrm{CH}_{2}\right), 1.48\left(3 \mathrm{H}, \mathrm{dd}, J=1.5,7 \mathrm{~Hz} ;-\mathrm{O}-\mathrm{CH}=\mathrm{CH}-\mathrm{CH}_{3}\right), 1.40-1.34$ $\left(2 \mathrm{H}, \mathrm{m}\right.$; DAP 4- $\left.\mathrm{CH}_{2}\right), 1.33-1.34\left(6 \mathrm{H}, \mathrm{m}\right.$; Lac- $\mathrm{BCH}_{3}$, Ala- $\left.\mathrm{BCH}_{3}\right)$; ESITOF-MS (positive): $m / z: 1581.73[M+\mathrm{H}]^{+}$

1- $O$-Deprotected disaccharide tetrapeptide 58 and 1- $O$-deprotected disaccharide tripeptide 59: Compounds $\mathbf{5 8}$ and $\mathbf{5 9}$ were synthesized from $\mathbf{5 6}$ and $\mathbf{5 7}$, respectively, in a manner similar to the synthesis of $\mathbf{4 1}$.
Compound 58: ${ }^{1} \mathrm{H}$ NMR $\left(500 \mathrm{MHz}, \mathrm{CDCl}_{3}\right): \delta=7.35-7.24(35 \mathrm{H}, \mathrm{m}$; $\mathrm{ArH}), 5.58\left(2 \mathrm{H}\right.$, br s; $\left.\mathrm{Ph}-\mathrm{CH}=\mathrm{O}_{2}, \mathrm{H}-1\right), 5.15-5.06\left(9 \mathrm{H}, \mathrm{m} ;{ }^{-} \mathrm{COO}-\mathrm{CH}_{2}-\right.$ $\left.\mathrm{Ph} \times 4, \mathrm{H}-1^{\prime}\right), 4.87\left(1 \mathrm{H}, \mathrm{d}, J=12 \mathrm{~Hz} ;-\mathrm{O}-\mathrm{CH}_{2} \mathrm{Ph}\right), 4.75(1 \mathrm{H}, \mathrm{d}, J=12 \mathrm{~Hz}$; $\left.-\mathrm{O}-\mathrm{CH}_{2} \mathrm{Ph}\right), 4.64\left(1 \mathrm{H}, \mathrm{d}, J=12 \mathrm{~Hz} ;-{ }^{-} \mathrm{O}-\mathrm{CH}_{2} \mathrm{Ph}\right), 4.52-4.36(8 \mathrm{H}, \mathrm{m}$; Lac- $\alpha \mathrm{H}$, Ala- $\alpha \mathrm{H}$, D-Ala- $\alpha \mathrm{H}$, Glu- $\alpha \mathrm{H}$, DAP 2-H, DAP 6-H, H-6', -O$\left.\mathrm{CH}_{2} \mathrm{Ph}\right), 4.02-3.94$ (2 H, m; H-6, H-3'), 3.77-3.43 (7 H, m; H-2, H-3, H-4, H-6, H-2', H-4', H-6'), 3.34-3.26 (2 H, m; H-5, H-5'), 2.33-1.97 (4 H, m; Glu- $\beta_{\mathrm{CH}_{2}}$, Glu- $\left.\gamma \mathrm{CH}_{2}\right), 1.97$ (3 H, s; NHAc), 1.72 (3H, s; NHAc), $1.85-$ $1.36\left(4 \mathrm{H}, \mathrm{m}\right.$; DAP $3-\mathrm{CH}_{2}$, DAP 4- $\mathrm{CH}_{2}$, DAP 5- $\left.\mathrm{CH}_{2}\right), 1.38-1.31 \mathrm{ppm}(6 \mathrm{H}$, $\mathrm{m} ; \quad \mathrm{Lac}-\mathrm{\beta CH}_{3}$, Ala- $\beta \mathrm{CH}_{3}$ ); ESI-TOF-MS (positive): $\mathrm{m} / \mathrm{z}: 1612.84$ $[M+\mathrm{H}]^{+}$

Compound 59: ${ }^{1} \mathrm{H}$ NMR $\left(500 \mathrm{MHz}, \mathrm{CDCl}_{3}\right): \delta=7.40-7.17(35 \mathrm{H}, \mathrm{m}$; $\mathrm{ArH}), 5.58\left(2 \mathrm{H}\right.$, brs; $\left.\mathrm{Ph}-\mathrm{CH}=\mathrm{O}_{2}, \mathrm{H}-1\right), 5.16-5.05\left(9 \mathrm{H}, \mathrm{m} ;-\mathrm{COO}-\mathrm{CH}_{2}-\right.$ $\left.\mathrm{Ph} \times 4, \mathrm{H}-1^{\prime}\right), 4.87\left(1 \mathrm{H}, \mathrm{d}, J=12 \mathrm{~Hz} ;-\mathrm{O}-\mathrm{CH}_{2} \mathrm{Ph}\right), 4.74(1 \mathrm{H}, \mathrm{d}, J=12 \mathrm{~Hz}$; $\left.-\mathrm{O}-\mathrm{CH}_{2} \mathrm{Ph}\right), 4.64\left(1 \mathrm{H}, \mathrm{d}, J=12 \mathrm{~Hz} ;-\mathrm{O}-\mathrm{CH}_{2} \mathrm{Ph}\right), 4.56-4.34(9 \mathrm{H}, \mathrm{m}$; Lac- $\alpha \mathrm{H}$, Ala- $\alpha \mathrm{H}$, Glu- $\alpha \mathrm{H}$, DAP 2-H, DAP 6-H, H-6, H- $\left.{ }^{\prime},-\mathrm{O}-\mathrm{CH}_{2} \mathrm{Ph}\right)$, 4.02-3.94 (2 H, m; H-6, H-3'), 3.83-3.43 (7 H, m; H-2, H-3, H-4, H-6, H$\left.2^{\prime}, \mathrm{H}-4^{\prime}, \mathrm{H}-6^{\prime}\right), 3.35-3.31$ (1 H, m; H-5), 3.29-3.24 (1 H, m; H-5'), 2.31$1.98\left(4 \mathrm{H}, \mathrm{m}\right.$; Glu- $\left.\beta \mathrm{CH}_{2}, \mathrm{Glu}-\gamma \mathrm{CH}_{2}\right), 1.96(3 \mathrm{H}, \mathrm{s} ; \mathrm{NHAc}), 1.73(3 \mathrm{H}, \mathrm{s}$; NHAc), $1.84-1.32\left(6 \mathrm{H}, \mathrm{m}\right.$; DAP 3- $\mathrm{CH}_{2}$, DAP 4- $\mathrm{CH}_{2}$, DAP 5- $\left.\mathrm{CH}_{2}\right), 1.39-$ $1.25 \mathrm{ppm}\left(6 \mathrm{H}, \mathrm{m}\right.$; $\mathrm{Lac}-\mathrm{\beta CH}_{3}$, Ala- $\left.\beta_{\mathrm{CH}}\right)$; ESI-TOF-MS (positive): $\mathrm{m} / \mathrm{z}$ : $1541.79[M+\mathrm{H}]^{+}$

Disaccharide tetrapeptide 1 and disaccharide tripeptide 2: Compounds 1 and $\mathbf{2}$ were synthesized from $\mathbf{5 8}$ and $\mathbf{5 9}$, respectively, in a manner similar to the synthesis of $\mathbf{5}$.

Compound 1: ${ }^{1} \mathrm{H}$ NMR $\left(500 \mathrm{MHz}, \mathrm{D}_{2} \mathrm{O}\right): \delta=5.07(1 \mathrm{H}, \mathrm{d}, J=3.5 \mathrm{~Hz} ; \mathrm{H}-$ 1), 4.41-4.37 (2 H, m; Ala- $\left.\alpha \mathrm{H}, \mathrm{H}-1^{\prime}\right), 4.20-4.03(5 \mathrm{H}, \mathrm{m}$; Lac- $\alpha \mathrm{H}$, D-Ala$\alpha \mathrm{H}$, DAP 2-H, DAP 6-H, Glu- $\alpha \mathrm{H}), 3.80-3.78\left(2 \mathrm{H}, \mathrm{m} ; \mathrm{H}-6^{\prime} \times 2\right), 3.73-3.57$ $\left(5 \mathrm{H}, \mathrm{m} ; \mathrm{H}-2, \mathrm{H}-3, \mathrm{H}-4, \mathrm{H}-5, \mathrm{H}-5^{\prime}\right), 3.43-3.39\left(1 \mathrm{H}, \mathrm{m} ; \mathrm{H}-3^{\prime}\right), 3.35-3.27$ $\left(3 \mathrm{H}, \mathrm{m} ; \mathrm{H}-6 \times 2, \mathrm{H}-4^{\prime}\right), 2.22-1.94\left(4 \mathrm{H}, \mathrm{m}\right.$; Glu- $\left.\beta_{\mathrm{CH}_{2}}, \mathrm{Glu}-\gamma \mathrm{CH}_{2}\right), 1.90$ $\left(3 \mathrm{H}, \mathrm{s}\right.$; NHAc), $1.80\left(3 \mathrm{H}, \mathrm{s}\right.$; NHAc), 1.83-1.57 $\left(4 \mathrm{H}, \mathrm{m}\right.$; DAP 3- $\mathrm{CH}_{2}, 5-$ $\left.\mathrm{CH}_{2}\right), 1.33-1.25\left(2 \mathrm{H}, \mathrm{m}\right.$; DAP 4- $\left.\mathrm{CH}_{2}\right), 1.29(3 \mathrm{H}, \mathrm{d}, J=7.5 \mathrm{~Hz} ; \mathrm{Lac}-$ $\left.\beta \mathrm{CH}_{3}\right), 1.25\left(3 \mathrm{H}, \mathrm{d}, J=6.5 \mathrm{~Hz}\right.$; Ala- $\left.\beta \mathrm{CH}_{3}\right), 1.20(3 \mathrm{H}, \mathrm{d}, J=7 \mathrm{~Hz}$; D-Ala$\mathrm{BCH}_{3}$ ); ESI-TOF-MS (negative): $\mathrm{m} / z$ : $938.31[\mathrm{M}-\mathrm{H}]^{-}$; HRMS-ESI QTOF-MS (positive): $m / z$ : calcd for $\mathrm{C}_{37} \mathrm{H}_{61} \mathrm{~N}_{7} \mathrm{O}_{21}: 940.3999[M+\mathrm{H}]^{+}$; found: 940.4031

Compound 2: ${ }^{1} \mathrm{H}$ NMR $\left(500 \mathrm{MHz}, \mathrm{CD}_{3} \mathrm{OD}\right): \delta=5.20(1 \mathrm{H}$, brs; $\mathrm{H}-1)$ 4.59-4.58 (2 H, m; Ala- $\left.\alpha \mathrm{H}, \mathrm{H}-1^{\prime}\right), 4.43-4.42(4 \mathrm{H}, \mathrm{m}$; Lac- $\alpha \mathrm{H}$, DAP 2-H, DAP 6-H, Glu- $\alpha \mathrm{H}), 3.90-3.89(2 \mathrm{H}, \mathrm{m}$; H-6 $\times 2), 3.81-3.58(5 \mathrm{H}, \mathrm{m}$; H-2, H-3, H-4, H-5, H-5'), 3.43-3.29 (4H, m; H-3', H-6 $\left.\times 2, \mathrm{H}-4^{\prime}\right), 2.32-1.99$ $\left(4 \mathrm{H}, \mathrm{m}\right.$; Glu- $\mathrm{\beta CH}_{2}$, Glu- $\left.\gamma \mathrm{CH}_{2}\right), 1.97(3 \mathrm{H}, \mathrm{s} ; \mathrm{NHAc}), 1.95(3 \mathrm{H}, \mathrm{s}$; NHAc), $1.80-1.53$ (4H, m; DAP 3- $\mathrm{CH}_{2}$, DAP 4-CH, DAP 5- $\left.\mathrm{CH}_{2}\right), 1.40-$ $1.28 \mathrm{ppm}\left(6 \mathrm{H}, \mathrm{m}\right.$; $\mathrm{Lac}-\mathrm{BCH}_{3}$, Ala- $\left.\beta \mathrm{CH}_{3}\right)$; ESI-TOF-MS (negative): $\mathrm{m} / \mathrm{z}$ : $867.37[M-\mathrm{H}]^{-}$; HRMS-ESI QTOF-MS (positive) $\mathrm{m} / \mathrm{z}$ : calcd for $\mathrm{C}_{34} \mathrm{H}_{56} \mathrm{~N}_{6} \mathrm{O}_{20}: 869.3627[M+\mathrm{H}]^{+}$; found: 869.3622 .

HEK293T Bioassay for Nod1 stimulation: Ligand dependent NF- $\kappa$ B activation was determined by using $0.5 \times 10^{5}$ HEK293T cells transfected with expression plasmids of Nod1 (0.17 ng of pCMV-SPORT6-Nod1), in the presence of reporter plasmids, NF- $\kappa \mathrm{B}$ dependent pBxIV-luc, and control pEF1BOS- $\beta$-gal as described. ${ }^{[7]}$ Briefly, HEK293T cells were transfected with expression plasmids by the calcium phosphate method, and $8 \mathrm{~h}$ after transfection, cells were treated with a medium containing various ligands. $24 \mathrm{~h}$ after transfection, ligand-dependent NF- $\kappa \mathrm{B}$ activation was determined by the luciferase reporter assay.

\section{Acknowledgements}

This work was supported in part by Grants-in Aid for Scientific Research (No. 17310128, 17510178, and 19310144) from the Japan Society for the Promotion of Science, by grants from the Suntory Institute for Bioorganic Research (SUNBOR Grant), the Houansha Foundation, and from the Institute for Fermentation, Osaka (IFO).

[1] E. M. Creagh, L. A. O’Neill, Trends Immunol. 2006, 27, 352-357.

[2] S. E. Girardin, I. G. Boneca, L. A. Carneiro, A. Antignac, M. Jehanno, J. Viala, K. Tedin, M. K. Taha, A. Labigne, U. Zahringer, A. J. 
Coyle, P. S. DiStefano, J. Bertin, P. J. Sansonetti, D. J. Philpott, Science 2003, 300, 1584-1587.

[3] M. Chamaillard, M. Hashimoto, Y. Horie, J. Masumoto, S. Qiu, L. Saab, Y. Ogura, A. Kawasaki, K. Fukase, S. Kusumoto, M. A. Valvano, S. J. Foster, T. W. Mak, G. Nuñez, N. Inohara, Nat. Immunol. 2003, 4, 702-707.

[4] A. Uehara, Y. Fujimoto, A. Kawasaki, S. Kusumoto, K. Fukase, H. Takada, J. Immunol. 2006, 177, 1796-1804.

[5] N. Inohara, Y. Ogura, A. Fontalba, O. Gutierrez, F. Pons, J. Crespo, K. Fukase, S. Inamura, S. Kusumoto, M. Hashimoto, S. J. Foster, A. P. Moran, J. L. Fernandez-Luna, G. Nuñez, J. Biol. Chem. 2003, 278, 5509-5512.

[6] S. E. Girardin, I. G. Boneca, J. Viala, M. Chamaillard, A. Labigne, G. Thomas, D. J. Philpott, P. J. Sansonetti, J. Biol. Chem. 2003, 278, 8869-8872.

[7] M. Hasegawa, K. Yang, M. Hashimoto, J. H. Park, Y. G. Kim, Y. Fujimoto, G. Nuñez, K. Fukase, N. Inohara, J. Biol. Chem. 2006, 281, 29054-29063.

[8] P. Hysi, M. Kabesch, M. F. Moffatt, M. Schedel, D. Carr, Y. Zhang, B. Boardman, E. von Mutius, S. K. Weiland, W. Leupold, C. Fritzsch, N. Klopp, A. W. Musk, A. James, G. Nuñez, N. Inohara, W. O. Cookson, Hum. Mol. Genet. 2005, 14, 935-941.

[9] S. Weidinger, N. Klopp, L. Rummler, S. Wagenpfeil, N. Novak, H. J. Baurecht, W. Groer, U. Darsow, J. Heinrich, A. Gauger, T. Schafer, T. Jakob, H. Behrendt, H. E. Wichmann, J. Ring, T. Illig, J. Allergy Clin. Immunol. 2005, 116, 177-184.

[10] W. Eder, W. Klimecki, L. Yu, E. von Mutius, J. Riedler, C. BraunFahrlander, D. Nowak, O. Holst, F. D. Martinez, Allergy 2006, 61, $1117-1124$

[11] D. P. McGovern, P. Hysi, T. Ahmad, D. A. van Heel, M. F. Moffatt, A. Carey, W. O. Cookson, D. P. Jewell, Hum. Mol. Genet. 2005, 14, $1245-1250$

[12] T. Tanabe, I. Ishige, Y. Suzuki, Y. Aita, A. Furukawa, Y. Ishige, K. Uchida, T. Suzuki, T. Takemura, S. Ikushima, M. Oritsu, T. Yokoyama, Y. Fujimoto, K. Fukase, N. Inohara, G. Nuñez, Y. Eishi, Biochim. Biophys. Acta 2006, 1762, 794-801.

[13] J. Masumoto, K. Yang, S. Varambally, M. Hasegawa, S. A. Tomlins, S. Qiu, Y. Fujimoto, A. Kawasaki, S. J. Foster, Y. Horie, T. W. Mak, G. Nuñez, A. M. Chinnaiyan, K. Fukase, N. Inohara, J. Exp. Med. 2006, 203, 203-213

[14] M. Hasegawa, A. Kawasaki, K. Yang, Y. Fujimoto, J. Masumoto, E. Breukink, G. Nuñez, K. Fukase, N. Inohara, J. Biol. Chem. 2007, 282, 11757-11764.

[15] S. Inamura, K. Fukase, S. Kusumoto, Tetrahedron Lett. 2001, 42, 7613-7616

[16] S. Inamura, Y. Fujimoto, A. Kawasaki, Z. Shiokawa, E. Woelk, H. Heine, B. Lindner, N. Inohara, S. Kusumoto, K. Fukase, Org. Biomol. Chem. 2006, 4, 232-242.

[17] A. Roychowdhury, M. A. Wolfert, G. J. Boons, ChemBioChem 2005, 6, 2088-2097.

[18] N. Kubasch, R. R. Schmidt, Eur. J. Org. Chem. 2002, 2710-2726.

[19] W. E. Goldman, D. G. Klapper, J. B. Baseman, Infect. Immun. 1982, 36, $782-794$.

[20] R. S. Rosenthal, W. Nogami, B. T. Cookson, W. E. Goldman, W. J. Folkening, Infect. Immun. 1987, 55, 2117-2120.
[21] B. T. Cookson, H. L. Cho, L. A. Herwaldt, W. E. Goldman, Infect Immun. 1989, 57, 2223-2229.

[22] T. Kaneko, W. E. Goldman, P. Mellroth, H. Steiner, K. Fukase, S. Kusumoto, W. Harley, A. Fox, D. Golenbock, N. Silverman, Immunity 2004, 20, 637-649.

[23] C. R. Stenbak, J. H. Ryu, F. Leulier, S. Pili-Floury, C. Parquet, M. Herve, C. Chaput, I. G. Boneca, W. J. Lee, B. Lemaitre, D. MenginLecreulx, J. Immunol. 2004, 173, 7339-7348.

[24] J. G. Magalhaes, D. J. Philpott, M. A. Nahori, M. Jehanno, J. Fritz, L. Le Bourhis, J. Viala, J. P. Hugot, M. Giovannini, J. Bertin, M. Lepoivre, D. Mengin-Lecreulx, P. J. Sansonetti, S. E. Girardin, EMBO Rep. 2005, 6, 1201-1207.

[25] A. R. Jurgens, Tetrahedron Lett. 1992, 33, 4727-4730.

[26] R. M. Williams, C. Yuan, J. Org. Chem. 1992, 57, 6519-6527.

[27] R. C. Holcomb, S. Schow, S. Ayral-Kaloustian, D. Powell, Tetrahedron Lett. 1994, 35, 7005-7008.

[28] Y. Gao, P. Lane-Bell, J. C. Vederas, J. Org. Chem. 1998, 63, 2133 2143.

[29] F. A. Davis, V. Srirajan, J. Org. Chem. 2000, 65, 3248-3251.

[30] F. Paradisi, G. Porzi, S. Rinaldi, S. Sandri, Tetrahedron: Asymmetry 2000, 11, 1259-1262.

[31] P. N. Collier, I. Patel, R. J. K. Taylor, Tetrahedron Lett. 2001, 42, 5953-5954.

[32] P. N. Collier, A. D. Campbell, I. Patel, T. M. Raynham, R. J. K. Taylor, J. Org. Chem. 2002, 67, 1802-1815.

[33] J. L. Roberts, C. Chan, Tetrahedron Lett. 2002, 43, 7679-7682.

[34] A. Sutherland, J. C. Vederas, Chem. Commun. 2002, 224-225.

[35] R. Galeazzi, M. Garavelli, A. Grandi, M. Monari, G. Porzi, S. Sandri, Tetrahedron: Asymmetry 2003, 14, 2639-2649.

[36] M. D. Spantulescu, R. P. Jain, D. J. Derksen, J. C. Vederas, Org. Lett. 2003, 5, 2963-2965.

[37] A. R. Chowdhury, G. Boons, Tetrahedron Lett. 2005, 46, 1675-1678.

[38] K. Dzierzbicka, Pol. J. Chem. 2007, 81, 455-473, and references therein.

[39] P. Garner, S. Ramakanth, J. Org. Chem. 1986, 51, 2609-2612.

[40] P. R. Blakemore, W. J. Cole, P. J. Kocienski, A. Morley, Synlett 1998, 26-28.

[41] G. Mahler, G. Seraa, E. Manta, Synth. Commun. 2005, 35, 1481.

[42] B. K. Albrecht, R. M. Williams, Proc. Natl. Acad. Sci. USA 2004, 101, 11949-11954.

[43] T. Ikawa, H. Sajiki, K. Hirota, Tetrahedron 2005, 61, 2217-2231.

[44] S. Koshida, Y. Suda, Y. Fukui, J. Ormsby, M. Sobel, S. Kusumoto, Tetrahedron Lett. 1999, 40, 5725-5728.

[45] J. Xue, Z. Guo, Tetrahedron Lett. 2001, 42, 6487-6489.

[46] J. J. Oltvoort, C. A. A. Van Boeckel, J. H. De Koning, J. H. Van Boom, Synthesis 1981, 305-307.

[47] M. A. Nashed, L. Anderson, J. Chem. Soc. Chem. Commun. 1982 1274-1276.

[48] M. A. Wolfert, A. Roychowdhury, G. J. Boons, Infect. Immun. 2007, 75, 706-713.

[49] T. Yano, S. Mita, H. Ohmori, Y. Oshima, Y. Fujimoto, R. Ueda, H. Takada, W. E. Goldman, K. Fukase, N. Silverman, T. Yoshimori, S. Kurata, Nat. Immunol. 2008, 9, 908-916.

Received: June 9,2008 Published online: October 1, 2008 